
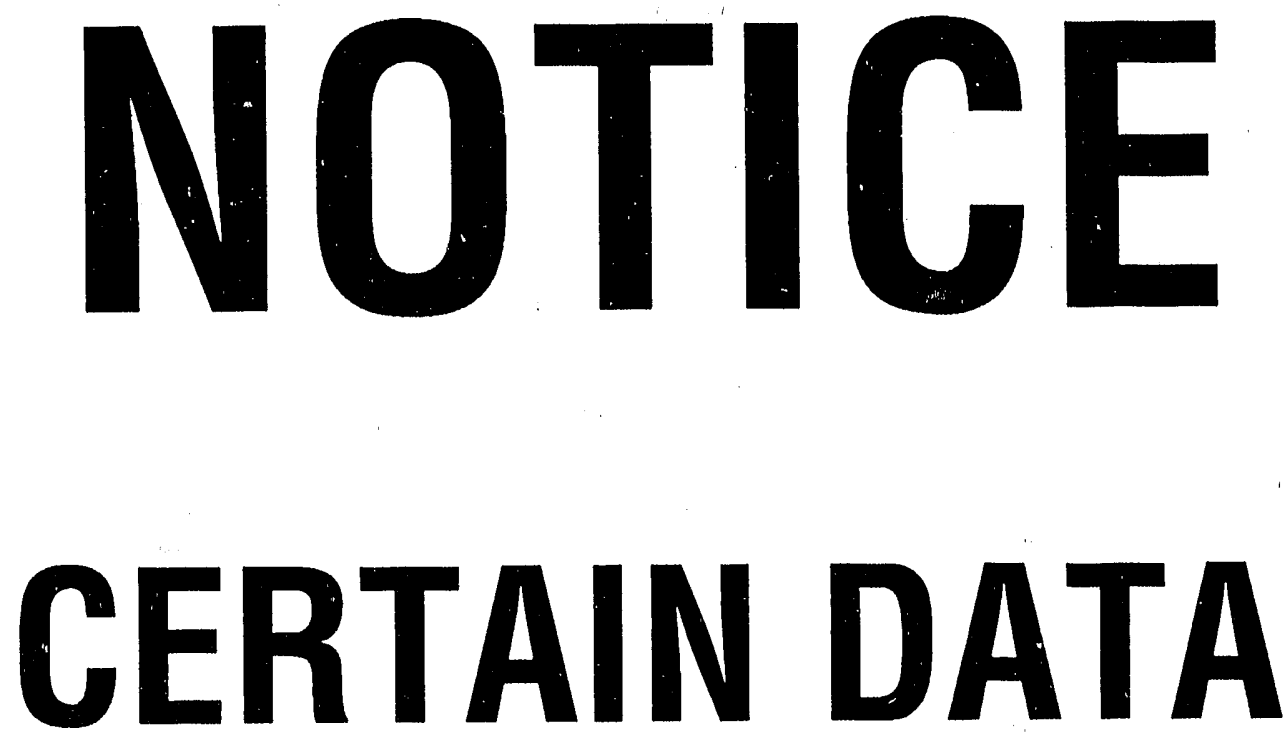

CONTAINED IN THIS
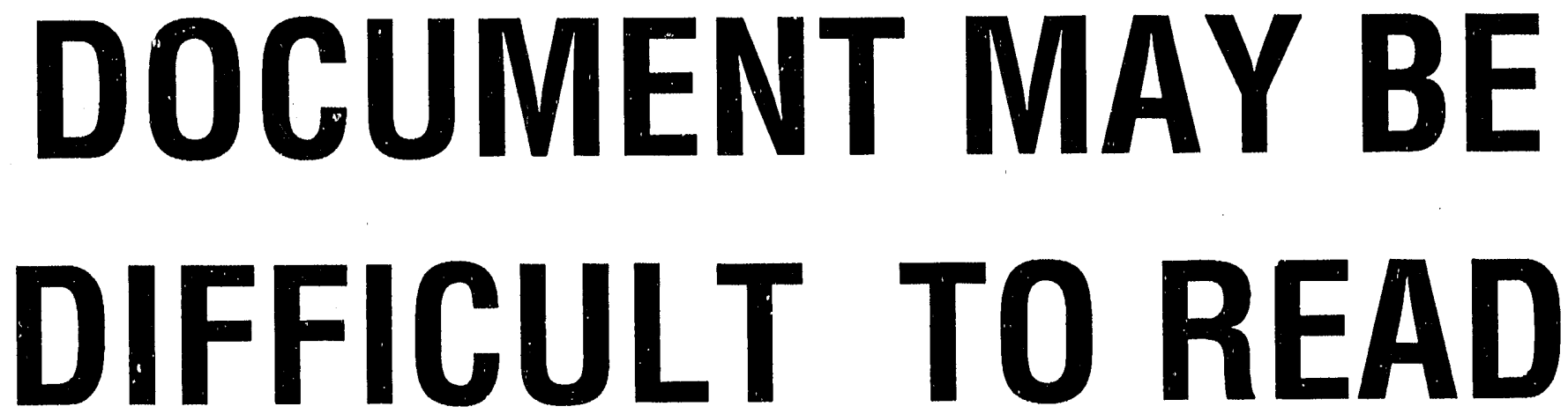

IN MICROFICHE

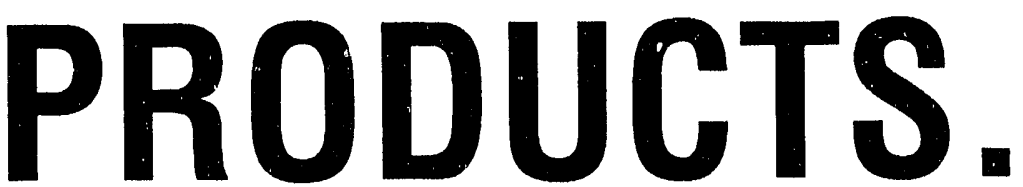


ADV ANCED HEAT PUMP FOR THE RECOVERY OF VOLATILE ORGANIC COMPOUNDS

Final Report

Phase 1: Conceptual Design of an Advanced Brayton Cycle Heat Pump for the Recovery of Volatlle Organic Compounds

March 1992

Work Performed Under Contract No. FC07-88ID12707

For

U.S. Department of Energy Office of Industrial Technologies Washington, D.C.

By 3M Corporate Research Laboratory

St. Paul, Minnesota 


\section{DISCLAIMER}

This report was prepared as an account of work sponsored by an agency of the United States Government. Neither the United States Government nor any agency thereof, nor any of their employess, makes any warranty, express or implied, or assumes any legal liability or responsibility for the accuracy, completeness, or usefulness of any information, apparatus, product, or process disclosed, or represents that its use would not infringe privately owned rights. Reference herein to any specific commercial product, process, or service by trade name, trademark, manufacturer, or otherwise does not necessarily constitute or imply its endorsement, recommendation, or favoring by the United States Government or any agency thereof. The views and opinions of authors expressed herein do not necessarily state or reflect those of the United States Government or any agency thereof.

This report has been reproduced directly from the best available copy.

Available to DOE and DOE contractors from the Office of Scientific and Technical Information, P.O. Box 62, Oak Ridge, TN 37831; prices available from (615)576-8401.

Available to the public from the National Technical Information Service, U. S. Department of Commerce, 5285 Port Royal Rd., Springfield, VA 22161. 


\title{
ADVANCED HEAT PUMP FOR THE RECOVERY \\ OF VOLATILE ORGANIC COMPOUNDS
}

\section{Final Report}

Phase 1: Conceptual Design of an Advanced Brayton Cycle Heat Pump for the Recovery of Volatile Organic Compounds

March 1992

Work Performed Under Cooperative Agreement

DE-FC07-88ID12707

\author{
Prepared for the \\ U.S. Dapartment of Energy \\ Under DOE Idaho Field Office \\ Sponsored by the Office of the Assistant Secretary \\ for Conservation and Renewable Energy \\ office of Industrial Technologies \\ Washington, D.C. \\ Prepared by \\ 3M Division Engineering \\ P. 0 . Box 33331 \\ St. Pau1, Minnesota 55133-3331 \\ $612 / 7331110$
}




\section{EXECUTIVE SUMMARY}

Emissions of Volatile Organic Compounds (VOC) from stationary industrial and commercial sources represent a substantial portion of the total U.S. VOC emissions. The 'Toxic-Release Inventory' of The U.S. Environmental Protection Agency estimates this to be at about 3 billion pounds per year (1987 estimates). The majority of these VOC emissions are from coating processes, cleaning processes, polymer production, fuel production and distribution, foam blowing, refrigerant production, and wood products production.

The U.S. Department of Energy's (DOE) interest in the recovery of VOC stems from the energy embodied in the recovered solvents and the energy required to dispose of them in an environmentally acceptable manner. This Phase I report documents 3M's work in close working relationship with its subcontractor Nuclear Consulting Services (Nucon) for the preliminary conceptual design of an advanced Brayton cycle heat pump for the recovery of VOC. Nucon designed Brayton cycle heat pump for the recovery of methyl ethyl ketone and toluene from coating operations at $3 \mathrm{M}$ Weatherford, $\mathrm{OK}$, was used as a base line for the work under cooperative agreement between $3 M$ and DOE. See appendix $A$ and reference (4) by Kovach of Nucon.

This cooperative agreement report evaluates and compares an advanced Brayton cycle heat pump for solvent recovery with other competing technologies for solvent recovery and reuse. This advanced Brayton cycle heat pump is simple (very few components), highly reliable (. 'f the shelf components), energy efficient and economically priced. 
As a result of work and efforts under this DOE/3M cooperative agreement, Nucon has been successful in commercializing the Brayton cycle heat pump technology under its trade names of 'Braysorb' and 'Braycycle'. Nucon has designed and manufactured a small mobile truck mounted VOC recovery system. This was funded by DOE, Southern California Edison, Electrical Power Research Institute, and $3 \mathrm{M}$ (in-kind contribution). Both $3 \mathrm{M}$ and Nucon have presented technical papers on Brayton cycle heat pump at American Society of Mechanical Engineers, American Institute of Chemical Engineers, and DOE sponsored conferences.

3M's interest in this technology is for the recovery of solvents from its coating operations. $3 \mathrm{M}$ is working closely with DOE to implement the conceptual design of an advanced Brayton cycle heat pump for solvent recovery at its Greenville, SC operations. This installation will be used for data collection, analysis and technology demonstration by $3 \mathrm{M}$ and DOE. 


\section{TABLE OF CONTENTS}

Executive Summary

Table of Contents

iii

List of Figures

iv

List of Tables

v

Report Outline

vi

1.0 Introduction

1

2.0 Objectives and Goals 2

3.0 Project Application 3

4.0 Description of Brayton Cycle Heat Pump . 4

5.0 Project Background 7

$\begin{array}{ll}\text { 6.0 Advanced Brayton Cycle } & 10\end{array}$

7.0 Competing Technologies 12

$\begin{array}{lll}8.0 \text { Summary } & 18\end{array}$

Appendix A Weatherford Brayton Cycle Heat Pump Appendix B Mobile Brayton Cycle System Design 


\section{LIST OF FIGURES}

FIGURES

PAGE

3.1 Small Mobile Brayton Cycle Heat Pump System 4

4.1 Description of Reverse Brayton Cycle with Solvent 6 Recovery

5.1 Simplified 9000 SCFM 3M Hutchinson Brayton 8 System

5.2 3M Weatherford Brayton/Concentrator System- $\quad 10$ Overall Process

6.1 Advanced Brayton/Adsorption System for 3M Greenville 11 Plant (Nucon 'Braysorb'TM Process)

6.2 Temperature versus Pressure Plot of 'Braysorb'M 12 Process

7.1 Steam Regeneration System with Decanting 13 Solvent/Water Separation

7.2 Reverse Rankine Cooled/Inert Gas Regeneration 14 System

7.3 Regenerative Incineration System 


\section{LIST OF TABLES}

NUMBER

PAGE

7.1 Cost and Performance Comparison of Four VOC Control

Designs for the 3M Greenville, SC Plant

7.2 Brayton Regenerated System Cost breakdown 16

7.3 Steam Regenerated System Cost Breakdown 16

7.4 Rankine Regenerated System Cost Breakdown 17

7.5 Cost breakdown of Installation of VOC Control 17

8.1 Progression of Cost and Performance 19 


\section{REPORT OUTLINE}

Cooperative Agreement No. DE-FCO7-881D12707 between 3M and DOE is for Phase I of the three phase program. These three phases are defined as follows:

Phase I: Conceptual Design of an Advanced Brayton Cycle Heat Pump Solvent Recovery System.

Phase II: Final Design, Fabrication and Installation of the Brayton Cycle Heat Pump for Solvent Recovery at Greenville, SC.

Phase III: Testing, Data Reporting and Operational Evaluation

This report is for Phase I work only and is outlined as follows. Section 1.0 is an Introduction. Section 2.0 is DOE and 3 M Objectives and Goals. Section 3.0 describes the Project Application. Section, 4.0 is a description of the Brayton Cycle Heat Pump. Section 5.0 is Project Background. Section 6.0 describes the Advanced Brayton Cycle Heat Pump. Section 7.0 describes competing technologies with cost and performance comparisons for the Greenville installation. And section 8.0 is the summary. 


\subsection{INTRODUCTION}

The use of solvents in industry is widespread. Solvent use affects a large crosssection of products such as adhesive tape, plastic foams, synthetic fibers, electronic components, furniture manufacturing and many more. Recently, environmental concerns have prompted stricter legislation to control VOC emissions (i.e. The Clean Air Act). At the same time the price of scime solvents has increased significantly, forcing industry to search for cost effective alternatives to manufacture profitably, yet within environmental regulations. Industry is thus presented with the following choices:

1) Eliminate the need for solvents in the manufacture of their product.

2) Reduce VOCs by making the process "tighter" (i.e. prevent fugitive emissions).

3) Control VOCs by incineration or destruction.

4) Control VOCs by capturing and recycling them back to reusable solvent.

$3 \mathrm{M}$ uses solvents to manufacture a variety of products (eg. adhesive tape, magnetic tape or discs, and other products requiring coating). A corporate wide effort has been implemented by the top management to reduce VOC emissions 90 percent by the year 2000 . Therefore, all of the four choices above are being considered.

Controlling VOCs by capture on activated carbon adsorption beds is common in industry today. Although the number of solvent control devices is in the thousands in the U.S., the level of VOCs that are controlled is a small fraction of the total VOC emissions. The U.S. DOE recognizes the potential for solvent recycling throughout the nation as an opportunity to save a significant amount of 
energy (50 trillion BTUs annually valued at over 200 million dollars). This energy savings will result from more energy efficient VOC control equipment to be brought to the marketplace, and the saving of the embodied energy of the solvent (i.e. the aggregate of the process energy and feedstock fuel heating value energy required to manufacture the solvent ).

Work under Phase I of the 3M/DOE cooperative agreement addresses these concerns. The advanced Brayton cycle heat pump solvent recovery system at Greenville, SC (Phase II) will recover better than $95 \%$ of the VOC's emitted and will reuse this in the tape manufacturing process.

\subsection{OB.JECTIVES AND GOALS}

Throughout Phase I work, both DOE and $3 \mathrm{M}$ had common objectives and goals to provide a conceptual design of an advanced Brayton cycle heat pump for solvent recovery, that is highly reliable, energy efficient and economically priced.

The first goal is to demonstrate economic solvent recovery for large VOC emission points (e.g. a 1000 ton per year VOC source). A payback of less than three years based on the total installed cost of the equipment with solvents moderately priced at 30 cents per pound, independent of environmental regulatory costs, is a target that DOE and $3 \mathrm{M}$ want to achieve.

The second goal is directed at small solvent users of less than $\mathbf{5 0 0}$ tons per year. The mobile BCHP should demonstrate to small solvent users (100 tons per year on average) that the annualized 
costs of this technology can control many different types of VOC sources at under $\$ 1000$ per ton.

Of course, these two goals must be achieved concurrent with reliable equipment, energy efficient equipment and equipment able to meet environmental regulations.

\subsection{PROJECT APPLICATION}

Tha Large VOC Control Application

$3 \mathrm{M}$ and the U.S. DOE are wurking cooperatively to develop an advanced $B C H P$ system. DOE and $3 M$ will cost-share the design, manufacture and field testing an $3000 \mathrm{scfm}$ BCHP system that will be installed at the $3 \mathrm{M}$ Greenville, SC, manufacturing plant to control a 1000 ton per year VOC emission source. Nucon International of Columbus, Ohio, is assisting $3 \mathrm{M}$ on this project by providing process engineering, equipment design and, manufacture and installation of the packaged BCHP regeneration/VOC adsorption system.

\section{The Small VOC Control Application}

The Greenville plant application is a relatively large VOC control application. Because VOC emission sources greater than 500 tons per year probably account for less than 10 percent of the total nationwide VOC emissions, DOE is also working with Nucon International to develop a cost effective BCHP to control small VOC emission points (e.g. less than 500 tons per year). This project will demonstrate the concept of a single mobile BCHP system to regenerate numerous concentration beds at scattered industrial 
host site locations. In this way the capital cost of the mobile BCHP (estimated at $\$ 300,000$ to $\$ 400,000$ ) can be distributed amongst many industrial solvent users. Southern California Edison (SCE) and the Electric Power Research Institute (EPRI) are co-sponsoring this project with Nucon, $3 \mathrm{M}$ and the DOE, and therefore, the host sites will be located in the southern California area. Figure 3.1 shows the small mobile BCHP system that will initially be demonstrated to four companies in southern California. Applicability of the Brayton concept in solving their specific VOC recovery problem will be evaluated. See Appendix B for description of this system.

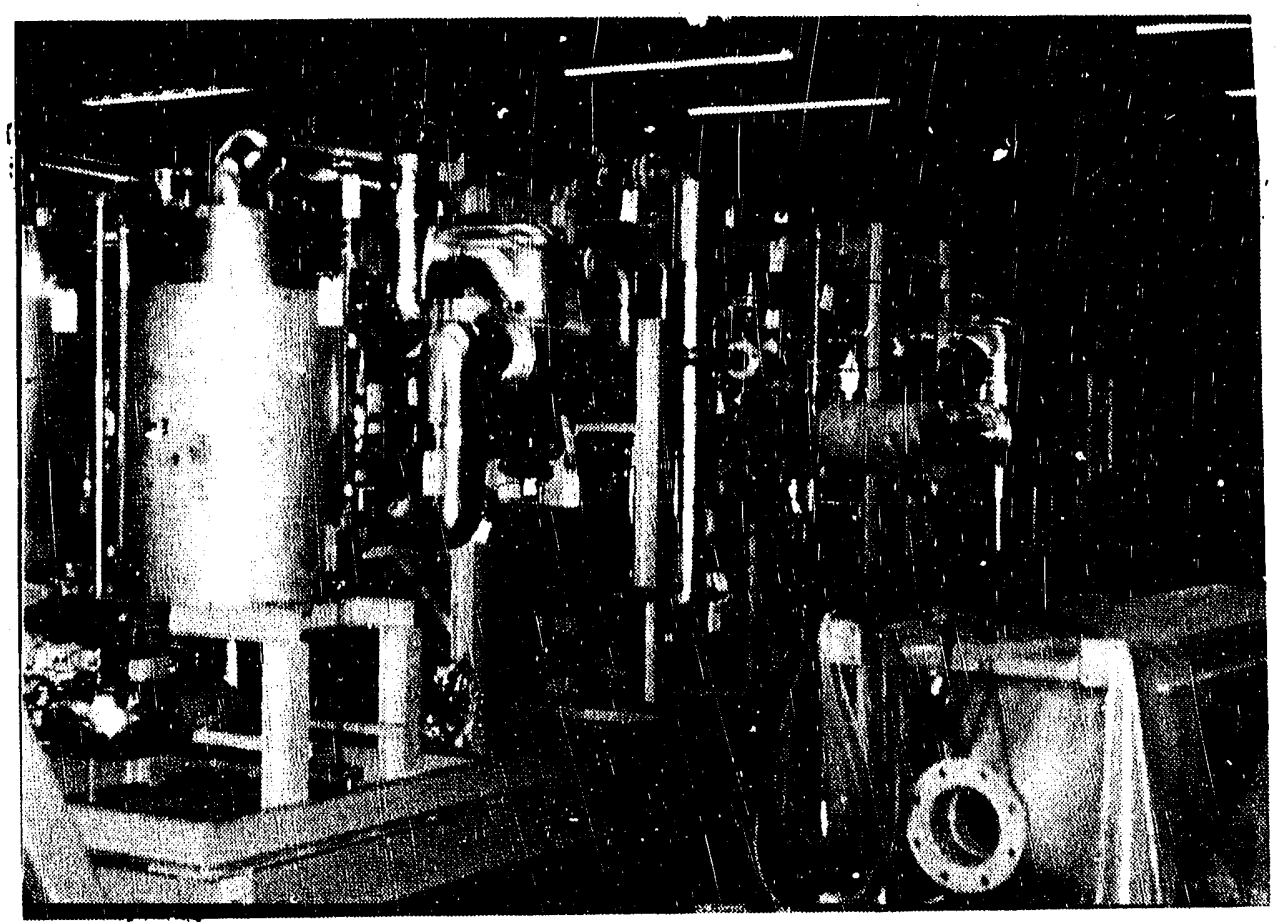

Figure 3.1 - Small Mobile Brayton Cycle Heat Pump System

\subsection{DESCRIPTION OF BRAYTON CYCLE}

The BCHP is an alternative means of condensing solvents from a gas stream by use of a reverse Brayton cycle. Many solvent streams must be refrigerated to temperatures below $-50^{\circ} \mathrm{F}\left(-45^{\circ} \mathrm{C}\right)$ to condense more than 90 percent of the 
solvent in a single pass through the condensing system. Other refrigeration methods, such as a reverse Rankine cycle using refrigerants in a closed cycle loop can also be and have been used to condense solvents to these low temperatures. (See table 7.1 for comparison of the Brayton cycle to the Rankine cycle and their costs).

To illustrate how refrigeration is accomplished with the reverse Brayton cycle, Figure 4.1 shows an ideal regenerative reverse Brayton cycle on a temperature/entropy diagram. At station 1 the solvent laden gas stream is compressed isentropically to station 2. Heat is extracted in the regenerator from station 2 to 3 at constant pressure. Because heat is extracted from station 2 to 3 the cycle is termed a reverse Brayton cycle. If heat was added by heat exchange or combustion (such as in a gas turbine power plant or jet engine), then the cycle would be a forward Brayton cycle. At station 3 the gas stream temperature will be ccld enough to condense a majority of the solvents. From station 3 to 4 the gas stream has work extracted isentropically in an expander (turbine) to lower the gas stream temperature even further. (Temperatures as low as $-150^{\circ} \mathrm{F}\left(-101^{\circ} \mathrm{C}\right)$ can be achieved in a single stage of compression and expansion). Essentially all of the remaining solvents are condensed at station 4. The work produced by the expander partially drives the compressor. The remainder of the compressor work requirement comes from mechanical shaft work input. The cold gases at station 4 are then passed through the other side of the regenerator to recoup heat at constant pressure to complete the cycle. 


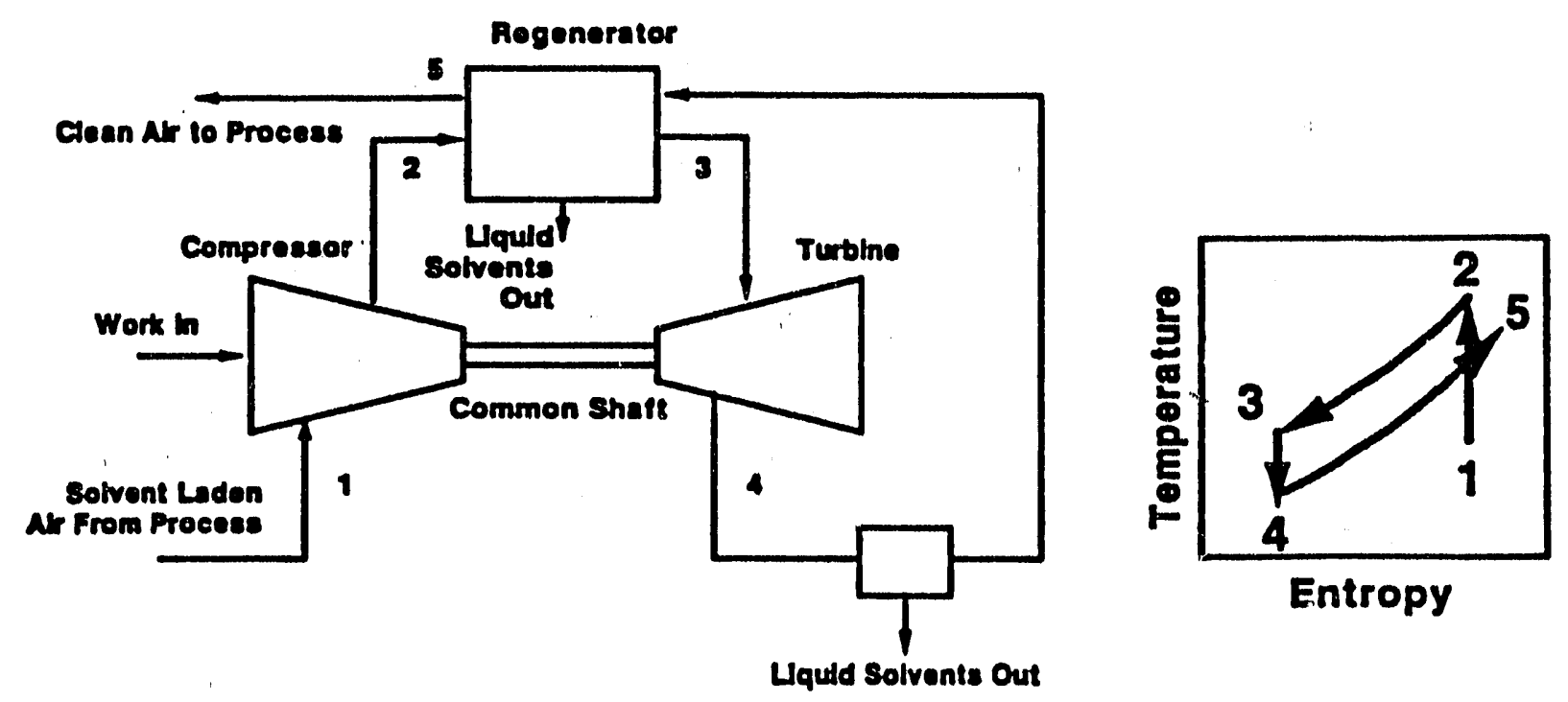

Figure 4.1 - Description of the Reverse Brayton Cycle with Solvent Recovery

Although the Brayton cycle requires high speed turbomachinery, this machinery is commonly used today. All air conditioning systems used on commercial and military jet aircraft use a reverse Brayton cycle system. For aircraft applications, the Brayton refrigeration method has been selected for reasons of low weight and high reliability. Another application of the reverse Brayton cycle is in cryogenic air separation plants. Here too, reliability has been good for over fifty years. At present, the most common application of the Brayton cycle is the automotive turbocharger. 


\subsection{PROJECT BACKGROUND}

$3 M$ has actively pursued the BCHP for the past 15 years. Bryce Fox (a retired $3 \mathrm{M}$ engineer) was the champion of this technology and is named sole or joint inventor on three $3 \mathrm{M}$ patents.

In 1979 3M funded the AiResearch Manufacturing Company (a civision of the Garrett Corporation) to provide a $2000 \mathrm{scfm}$ prototype Brayton cycle system. This was used to process a solvent laden gas stream from an inert gas drier at 3M. In showing feasibility and successful operation of this system, the U.S. DOE decided to fund a larger $9000 \mathrm{scfm}$ unit that was installed at 3M's Hutchinson, MN tape manufacturing plant. Both of these systems directly condense the solvents by processing the solvent laden air (SLA) from the coating process through the BCHP.

Both the 2000 and $9000 \mathrm{scfm}$ systems designed by AiResearch used specially manufactured gear boxes that were costly. The system installed at the Hutchinson plant (see Figure 5.1) shows the gear box coupling the input shaft power (an electric motor running at 3600 RPM) to a high speed compressor/turbine unit running at 16,500 RPM. 


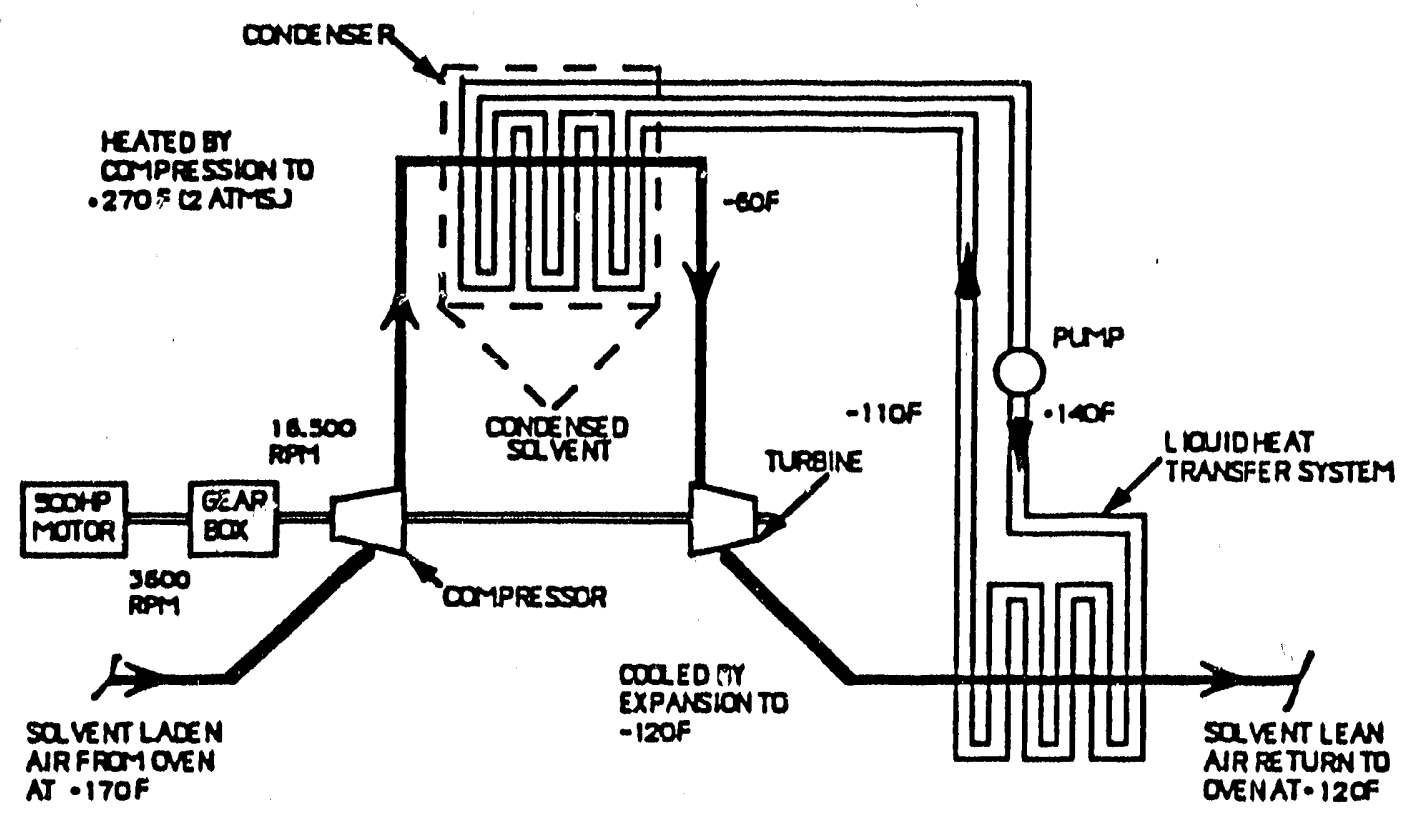

Figure 5.1 - Simplified 9000 scfm 3M Hutchinson Brayton System

Learning from the experiences of the Hutchinson system, $3 \mathrm{M}$ worked with Nucon to design and install the second industrial Brayton cycle system at the 3M Weatherford, OK plant beginning in 1985. The Weatherford design differed from the Hutchinson design as follows:

1) Activated carbon beds are use to adsorb and concentrate solvent from the VOC stream.

2) The BCHP is used to regenerate the carbon bed with inert nitrogen gas. The higher VOC concentration allowed in nitrogen leads to a smaller BCHP system than is possible in a direct condensation system. 
3) A molecular sleve is used as an intermediate step between the adsorption and regeneration of the carbon bed to eliminate water (and thus ice formation) from the BCHP solvent laden nitrogen stream.

4) A free spindle compressor-expander is used in combination with a rotary blower to provide the compressor/expansion package. That is, the shaft power input to the BCHP system was decoupled from the compressor/expander package to eliminate the high speed gear box used in the Hutchinson design thereby significantly reducing capital cost. This free spindle compressor/expander was a modified design of the Garrett Industrial Products Division's largest diesel turbocharger.

Figure 5.2 shows the overall solvent recovery process in which the two carbon beds are cycled between step 1 and steps 2 tu 4 . That is, while one bed is adsorbing solvents at step 1 , the other is being regenerated by step 2 (carbon dehydration), step 3 (carbon solvent desorption with the reverse Brayton cycle) and step 4 (molecular sieve regeneration).

The Weatherford system has been operating for over 2 years with over 99 percent up time and at $99 \%$ efficiency. A more detailed description of the Weatherford process is presented in reference (4) by Kovach of Nucon and under appendix $A$. 

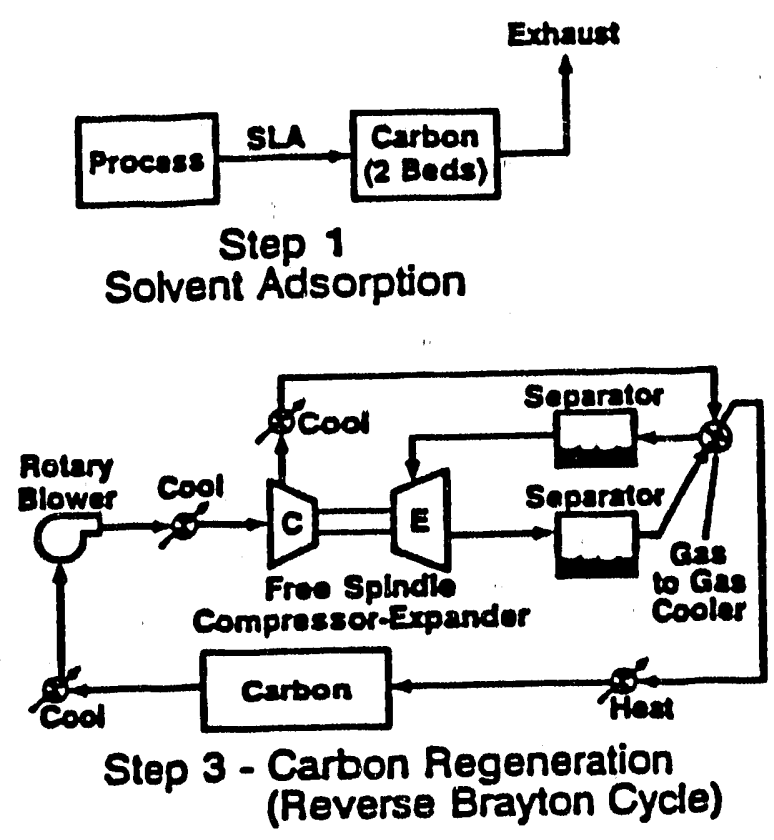

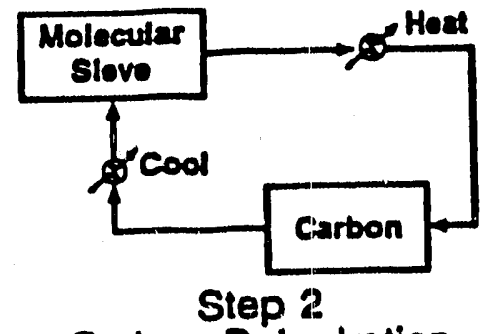

Carbon Dehydration

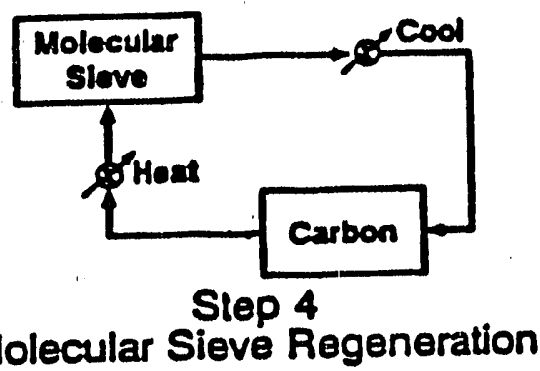

Figure 5.2 - 3M Weatherford Brayton/Concentrator System - Overall Process

\subsection{ADVANCED BRAYTON DESIGN}

In considering the recycle of solvents, equipment selection will be dictated by capital and operating cost. The solvent type, VOC stream flow size, VOC concentration level and the degree to which the VOC must be controlled (i.e. percent recovery) are all factors influencing cost.

To illustrate the economics of solvent recycling, the Greenville plant installation costs will be detailed for the proposed advanced Brayton design and for three alternative approaches to controlling the VOC, emissions from the coater at this plant. The VOC stream to be controlled at Greenville is an 8000 scfm SLA stream with a concentration of approximately 2000 ppmv. The solvents used are heptane, xylene, toluene and isopropylalcohol (IPA). 
Figure 6.1 shows the preliminary design of the advanced Brayton system. The Brayton regeneration system will provide a dry inert nitrogen stream for solvent stripping to one of the two adsorbent beds and then will remove over 99 percent of the solvents from the solvent laden nitrogen (SLN) once the SLN is returned from the adsorption bed. (The other adsorption bed is adsorbing solvents from the SLA stream coming from the coater.) This process was developed by Nucon under Phase 1 of the DOE project. The process is trade marked BRAYSORBTM. Figure 6.2 shows the temperature versus pressure plot of this system. Note that the temperature of the dry ritrogen returned to the adsorber is $320^{\circ} \mathrm{F}\left(160^{\circ} \mathrm{C}\right)$ and therefore no additional process heating is needed to regenerate the adsorbent beds. This means that electricity is only needed to drive the Brayton system, eliminating the need for steam production or auxiliary heating systems.

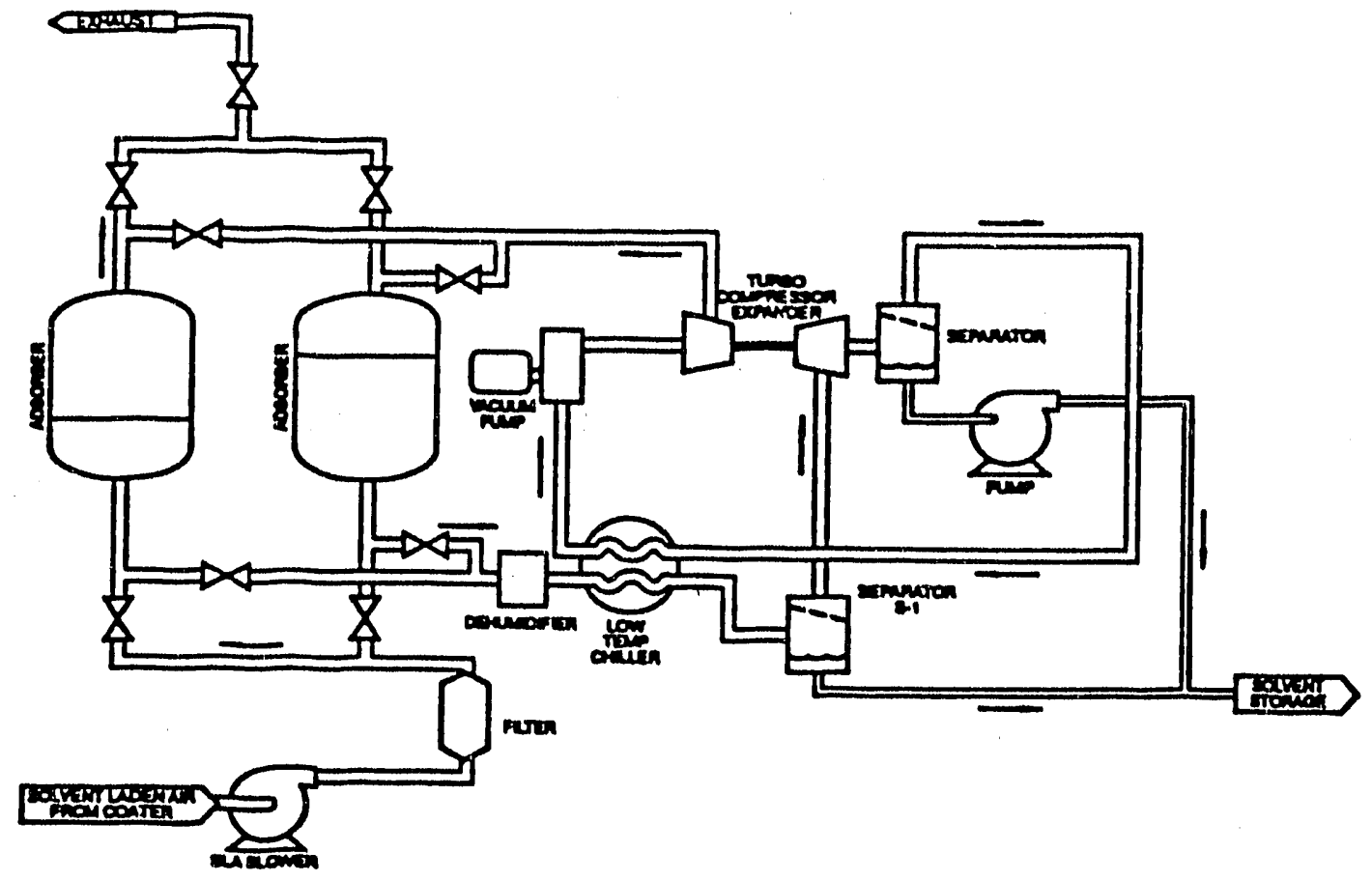

Figure o.1 - Advanced Brayton/Adsorption System for 3M Greenville Plant (Figure represents Nucon BRAYSORB ${ }^{\text {TM }}$ process) 


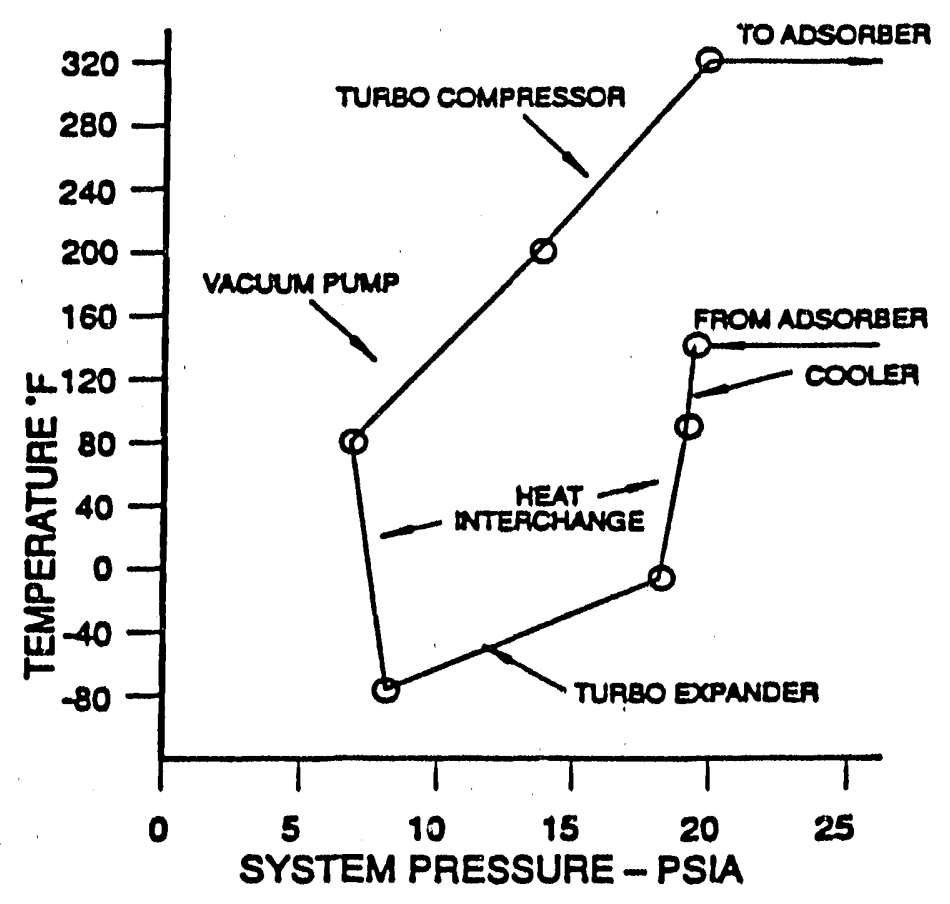

Figure 6.2 - Temperature versus Pressure Plot of BRAYSORB'M Process

\subsection{COMPETING TECHNOLOGIES}

Three competing technologies were evaluated and compared with the Brayton cycle heat pump solvent recovery system. For all these technologies, Greenville, SC, VOC emission data was used for cost comparisons. See tables 7.1 to 7.4 for these cost comparisons.

Figure 7.1 shows the generic steam regeneration system analyzed. If the solvents are not miscible or slightly miscible, a decanting system will separate the majority of the solvents from the steam condensate satisfactorily. The contaminated condensate, however, will need to be treated by an air stripper. If the solvents are miscible, a more costly distillation system is required. 


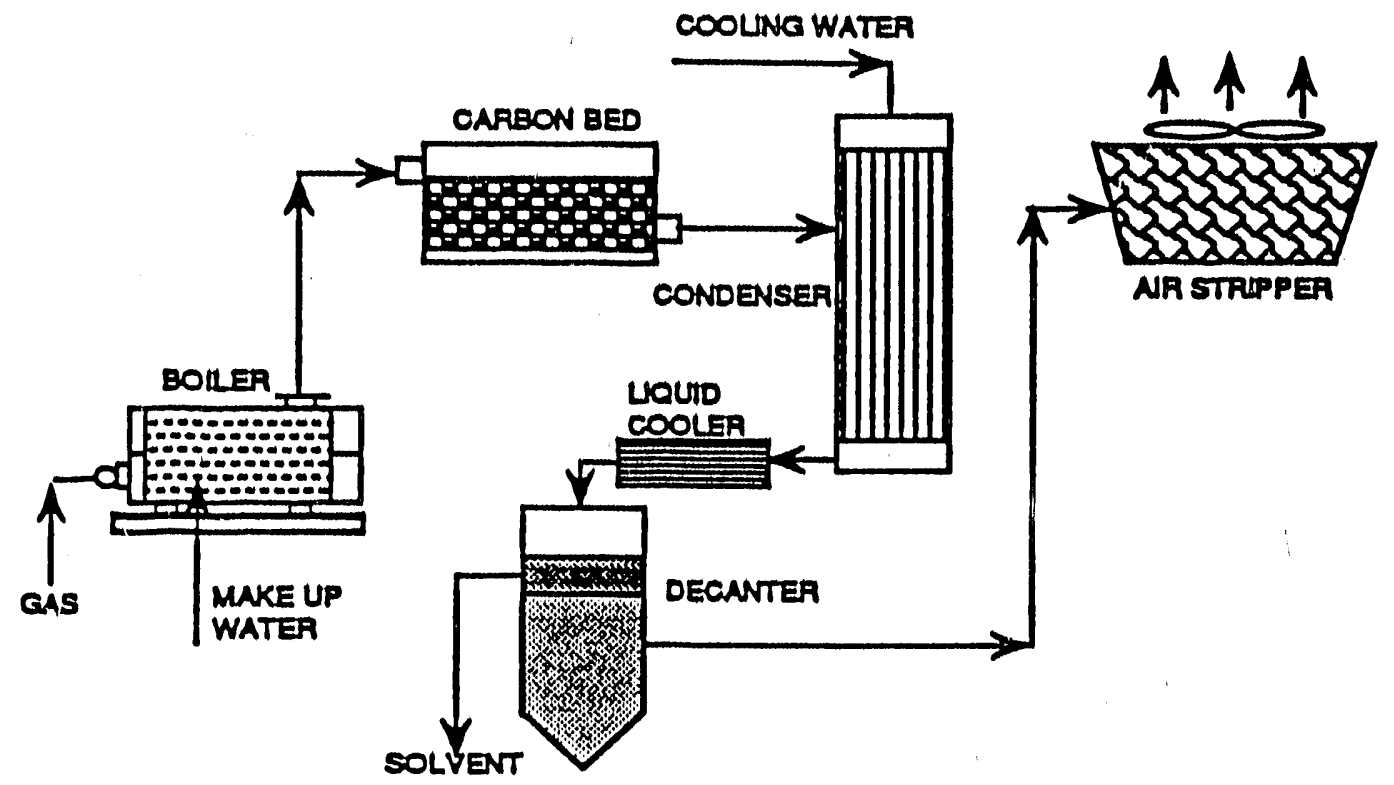

Figure 7.1 - Steam Regeneration System with Decanting Solvent/Water Separation

Figure 7.2 shows a schematic of a reverse Rankine system. This system has two cooling systems, one with a $30^{\circ} \mathrm{F}\left(-1^{\circ} \mathrm{C}\right)$ and one with a $-80^{\circ} \mathrm{F}=\left(-62^{\circ} \mathrm{C}\right)$ evaporator coil cooling temperature. Tha SLN stream is cooled to $-75^{\circ} \mathrm{F}:-59^{\circ} \mathrm{C}$ ), which is the same temperature as that achieved by the Brayton system. This allows for equal comparison of the Brayton and Rankine systems since approximately the same percent solvent recovery should be accomplished. 


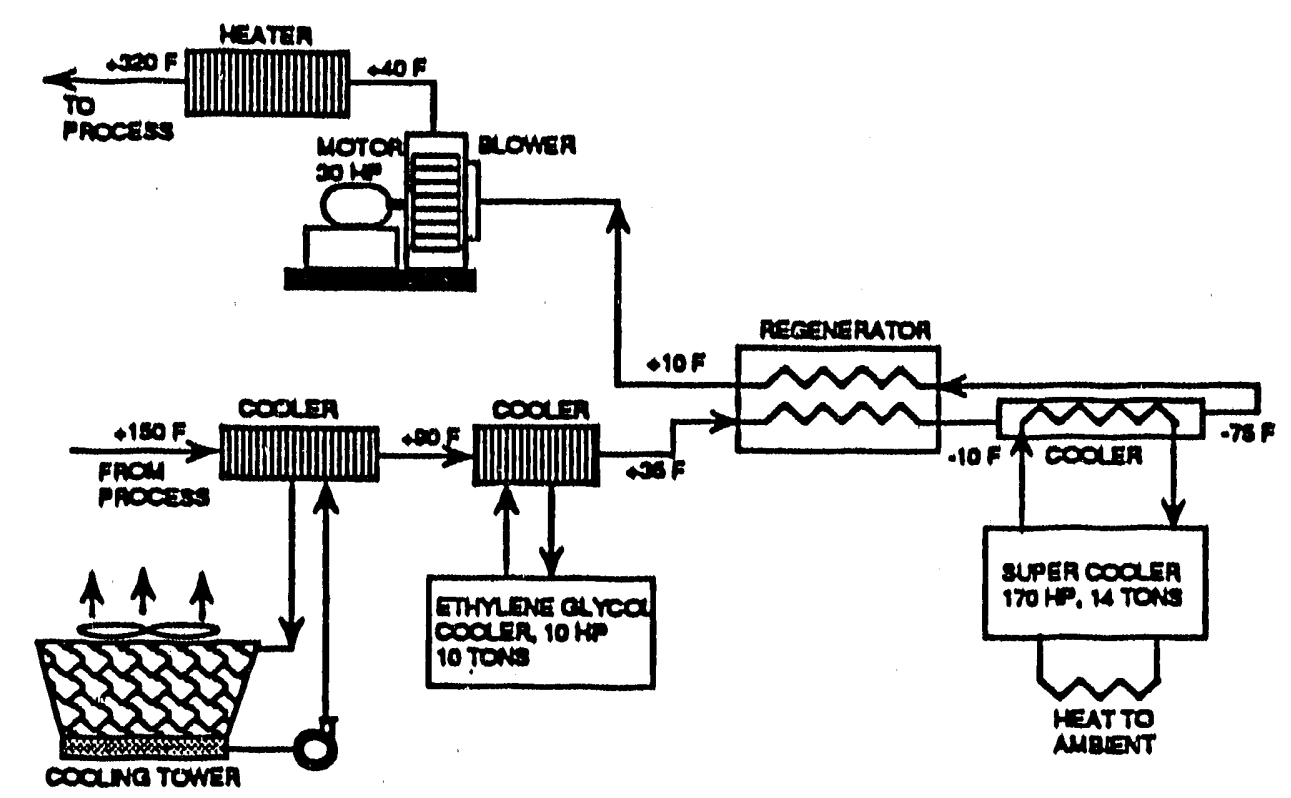

Figure 7.2 - Reverse Rankine Cooled/Inert Gas Regeneration System

Finally, an incineration system is shown in Figure 7.3. This system is a high efficiency unit with heat regeneration. The system as shown provides for no heat recovery to provide heat to the plant's utilities needs. The solvents that are burned can account for over 50 percent of the fuel heating value in the combustion process.

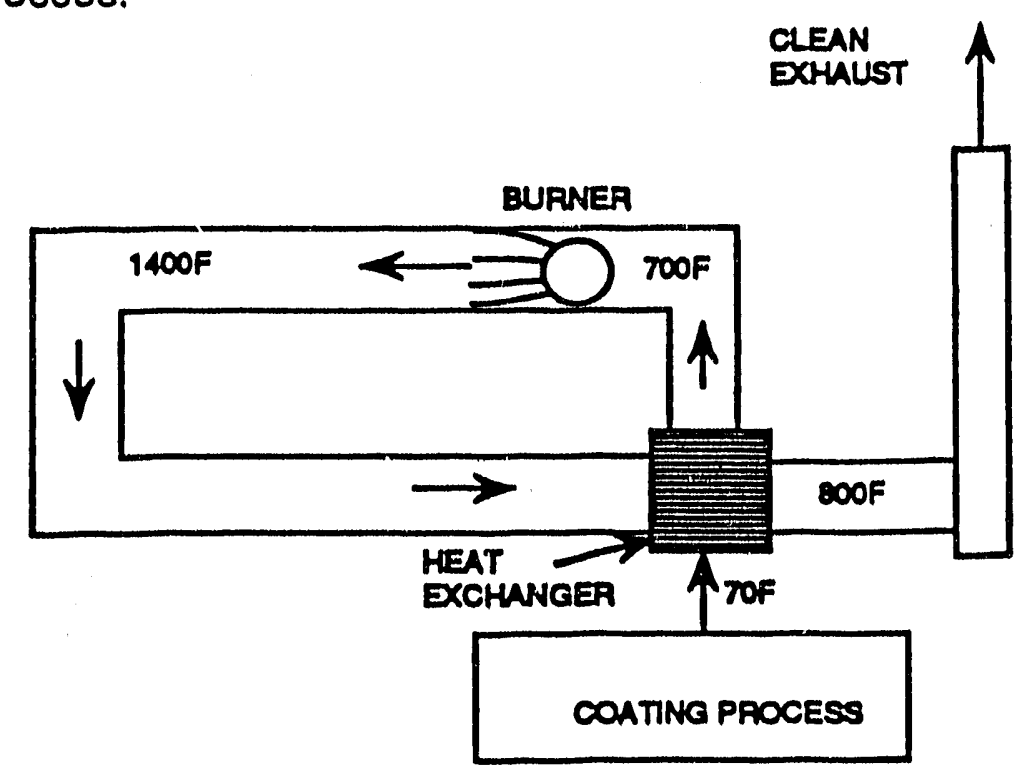

Figure 7.3 - Regenerative Incineration System 
Tables 7.1 compares cost and performance of these four systems. Tables 2 to 4 give a cost breakdown of the three recovery options. Table 5 estimates installation costs of the VOC control options.

\section{Table 7.1 - Cost and Performance Comparison of Four VOC Control Designs for the $3 \mathrm{M}$ Greenville, SC Plant}

\begin{tabular}{|c|c|c|c|c|}
\hline & Brayton & Steram & Rankine & Incineration \\
\hline Equipment Cost & $\begin{array}{l}\$ 565,000 \\
\text { (see Table 2) }\end{array}$ & $\begin{array}{l}\$ 500,000 \\
\text { (See Table 3) }\end{array}$ & $\begin{array}{l}\$ 625,000 \\
\text { (See Table 4) }\end{array}$ & $\$ 540,000$ \\
\hline $\begin{array}{l}\text { Installation Cost } \\
\text { (See Table 5) }\end{array}$ & $\$ 700,000$ & $\$ 800,000$ & $\$ 760,000$ & $\$ 360,000$ \\
\hline Total Capital Cost & $\$ 1,265,000$ & $\$ 1,300,000$ & $\$ 1,385,000$ & $\$ 900,000$ \\
\hline $\begin{array}{l}\text { Depreciation } \\
\text { \& Period }\end{array}$ & $\begin{array}{c}\$ 180,714 \\
7 \text { Years }\end{array}$ & $\$ \underset{185,714}{7 \text { Years }}$ & $\begin{array}{c}\text { \$ } 197857 \\
7 \text { Years }\end{array}$ & $\begin{array}{c}\text { \$ } 128,571 \\
7 \text { Years }\end{array}$ \\
\hline $\begin{array}{l}\text { Energy Requirement } \\
\text { \& (Type) }\end{array}$ & $139 \mathrm{KW}(\mathrm{E})$ & $\begin{array}{c}40 \mathrm{KW}(\mathrm{E}) \\
1.33 \mathrm{MMBH}(\mathrm{NG})\end{array}$ & $\begin{array}{c}180 \mathrm{KW} \text { (E) } \\
0.75 \mathrm{MMBH}(\mathrm{NG})\end{array}$ & $3.00 \mathrm{MMBH}(\mathrm{NG})$ \\
\hline Energy Cost * & $\$ 48,000$ & $\$ 56,000$ & $\$ 97,200$ & 77,800 \\
\hline $\begin{array}{l}\text { Inert Gas Cost * } \\
\& \text { (Amount) }\end{array}$ & $\begin{array}{l}\$ 3,000 \\
(800 \text { scf/day })\end{array}$ & 0 & $\begin{array}{l}\$ \quad 3,000 \\
(800 \text { scf/day) }\end{array}$ & 0 \\
\hline Labor Cost* & $\begin{array}{c}33,280 \\
16 \mathrm{hrs} / \mathrm{wk}\end{array}$ & $\begin{array}{c}\$ 33,280 \\
16 \mathrm{hrs} / \mathrm{wk}\end{array}$ & $\begin{array}{c}\$ 33,280 \\
16 \mathrm{hrs} / \mathrm{wk}\end{array}$ & $\begin{array}{r}\$ 16,640 \\
8 \mathrm{hrs} / \mathrm{wk}\end{array}$ \\
\hline $\begin{array}{l}\text { Maintenance Cost* } \\
\text { (\% of Equip Cost) }\end{array}$ & $\begin{array}{l}113,000 \\
(20 \%)\end{array}$ & $\begin{array}{l}100,000 \\
(20 \%)\end{array}$ & $\begin{array}{l}137,000 \\
(20 \%)\end{array}$ & $\$ \begin{array}{l}108,000 \\
(20 \%)\end{array}$ \\
\hline Total O\&M Cost & $\$ 197,280$ & $\$ 189,280$ & $\$ 270,480$ & $\$ 202,440$ \\
\hline $\begin{array}{l}\text { Solvent Recovery } \\
\text { (lbs per hour) } \\
\text { (lbs per year) }\end{array}$ & $\begin{array}{l}270 \\
2.33 \mathrm{MM}\end{array}$ & $\begin{array}{l}265 \\
2.28 \mathrm{MM}\end{array}$ & $\begin{array}{l}270 \\
2.33 \mathrm{MM}\end{array}$ & $\begin{array}{r}0 \\
0\end{array}$ \\
\hline $\begin{array}{l}\text { Solvent Savings } \\
\text { (\$'s per year) }\end{array}$ & $\$ 279,600$ & $\$ 274,000$ & $\$ 279,600$ & \\
\hline $\begin{array}{l}\text { Annualized Cost } \\
\text { (\$'s per year) }\end{array}$ & $\$ 98,34$ & $\$ 100,994$ & $\$ 188,737$ & $\$ 331,011$ \\
\hline $\begin{array}{l}\text { Simple Payback of } \\
\text { Recovery over } \\
\text { Incineration }\end{array}$ & 1.57 Yrs & $1.74 \mathrm{Yrs}$ & 3.4 Yrs & - \\
\hline $\begin{array}{l}\text { Simple Payback } \\
\text { (solvent at } \\
30 \text { cents per lb) }\end{array}$ & $2.5 \mathrm{Yrs}$ & 2.62 Yrs & $3.23 \mathrm{Yrs}$ & $\mathrm{NA}$ \\
\hline
\end{tabular}




\section{Economic Factors}

operation hours per year - 8640

electricity rate - 4 cents/Kw.-Hr

natural gas cost - $\$ 3.00 / \mathrm{MM}$ BTU

boiler efficiency - $75 \%$

labor rate - $\$ 40$ per $\mathrm{Hr}$

solvent recycle value - $\$ .12 / \mathrm{lb}$

* Costs are annual $\quad \mathrm{E}=$ Electricity $\quad \mathrm{NG}=$ Natural Gas $\quad \mathrm{MMBH}=$ Million $\mathrm{BTU} / \mathrm{Hr}$

Table 7.2 - Brayton Regenerated System Cost Breakdown

Free-spindle Compressor/Expander

$\$ 40,000$

Drive Compressor

$\$ 40,000$

Regenerative Heat Exchanger

$\$ 40,000$

Precooler (water cooling)

$\$ 10,000$

Piping \& Valves

$\$ 50,000$

Separators \& Receivers

$\$ 30,000$

Instrumentation \& Controls

$\$ 90,000$

Structural Skidding, Mounting, Misc.

$\$ 40,000$

Adsorber Structure (Carbon Steel)

$\$ 60,000$

Activated Carbon (20,000 lbs @ \$2/lb)

$\$ 40.000$

Total Equipment Cost

$\$ 440,000$

Engineering

$\$ 75,000$

Profit

$\$ 50.000$

Total Equipment Cost

$\$ 565,000$

Table 7.3 - Steam Regenerated System Cost Breakdown

Boiler (1000 lb/hr Steam)

Decanter \& Condenser

Piping \& Valves

Instrumentation \& Controls

Structural Skidding, Mounting, Misc.

Adsorber Structure (304 Stainless)

Activated Carbon (20,000 lbs @ \$2/lb)

Cooling Tower

Water Treatment System

$\$ 20,000$

$\$ 50,000$

$\$ 50,000$

$\$ 50,000$

$\$ 40,000$

$\$ 80,000$

$\$ 40,000$

$\$ 30,000$

Total Equipment Cost

$\$ 50.000^{*}$

Engineering

$\$ 410,000$

$\$ 50,000$

Profit

$\$ 40.000$

Total Equipment Cost

* Site dependent - Cost may be as high as $\$ 500,000$

$\$ 500,000$ 
Table 7.4 - Rankine Regenerated System Cost Breakdown

Precooler (water cooling)

Precooling Refrigeration Unit

Regenerative Heat Exchanger

Super-cooler Refrigeration Unit

Regenerator Blower

Heating Unit

Piping \& Valves

Separators \& Receivers

Instrumentation \& Controls

Adsorber Structure (Carbon Steel)

Activated Carbon (20,000 lbs @ \$2/lb)

$\$ 10,000$

$\$ 20,000$

$\$ 20,000$

Total Equipment Cost

Engineering

$\$ 150,000$

Profit

$\$ 10,000$

$\$ 10,000$

$\$ 50,000$

$\$ 30,000$

$\$ 90,000$

$\$ 60,000$

$\$ 40.000$

Total Equipment Cost

$\$ 490,000$

$\$ 75,000$

$\$ 60.000$

$\$ 625,000$

Table 7.5 - Cost Breakdown of Installation of VOC Control VOCRecovery

VOCIncineration

Engineering

SLA Fan, Filter, Cooler, Ducting

Site Preparation *

Tank Farms

Equipment Installation

Process Instrumentation

Total Installation Cost
$\$ 50,000$

$\$ 100,000$

$\$ 250,000$

$\$ 150,000$

$\$ 100,000$

$\$ 50: 000$

$\$ 700,000$
$\$ 50,000$

$\$ 100,000$

$\$ 120,000$

$\$ 0$

$\$ 40,000$

$\$ 50.000$

$\$ 360,000$

* Add $\$ 60,000$ for a building enclosure on the Rankine system

* Add $\$ 100,000$ for a cooling tower installation for a Steam system

A few conclusions can be made from the above tables:

1) All the solvent recovery technologies have lower annualized operating cost than incineration. Also, the incremental investment of all three recovery technologies over the cost of the incineration system yields a 1.5 to 3.5 years payback based on the aggregate savings of the recycled solvents and the difference in operating costs of the recovery options and incineration. In the future if the solvent price were, for instance, 30 cents 
per pound for this application then the payback on Brayton and steam regeneration system would be less then 3 years.

2) The Brayton system costs are estimated to be competitive with the well established recovery technologies. This cost estimate of the Brayton system is for the third generation design. Further cost reduction can be expected in the future. For this reason, $3 \mathrm{M}$ is pursuing this technology so that their choices on controlling VOCs may be broadened. Likewise, the DOE sees the Brayton technology as a vehicle to reduce energy consumption of VOC control technologies and, to proliferate solvent recycling with more cost effective recycling with both large and sma!l solvent users and thereby reduce demand for energy intensive solvent production nationwide.

\subsection{SUMMARY}

The main accomplishments over the last 15 years on the Brayton cycle solvent recovery technology have been to reduce capital cost, reduce energy consumption and improve reliability of the equipment. Table 8.1 summarizes the performance of the two $3 \mathrm{M}$ Brayton systems already installed (Hutchinson and Weatherford) and the expected performance of the planned Greenville plant installation. 
Table 8.1 - Progression of Cost and Performance Improvements with the BCHP at $3 \mathrm{M}$

\begin{tabular}{|c|c|c|c|}
\hline & Hutchinson & Weatherford & Greenville \\
\hline SLA Stream Size (scfm) & 9000 & 9000 & 8000 \\
\hline Time period designed \& Built & $1979-1984$ & $1985-1987$ & $1988-1991$ \\
\hline Solvent Type & $\begin{array}{l}\text { MEK, Toluene, } \\
\text { Cyclohexanone }\end{array}$ & $\begin{array}{l}\text { MEK, Toluene, } \\
\text { Cyclohexanone }\end{array}$ & $\begin{array}{c}\text { Heptane, Xylene } \\
\text { Toluene, IPA }\end{array}$ \\
\hline VOC Conc. (PPMV) & 4000 & 2000 & 2000 \\
\hline Power Required (HP) & 550 & 450 & 180 \\
\hline Equipment Cost & $\$ 1,500,000^{(1)}$ & $\$ 1,000,000^{(1)}$ & $\begin{array}{l}\$ 565,000 \\
\text { (From Table 2) }\end{array}$ \\
\hline
\end{tabular}

In summary, substantial improvements have been made on the Brayton cycle technology, especially in the last two years. Stricter environmental regulations for VOCs creates a demand in industry for VOC control equipment at reduced cost. Higher solvent prices will also further enhance the economics of solvent recycling over incineration. The DOE and $3 \mathrm{M}$ therefore remain committed to this technology.

A three phase cooperative effort between the U.S. DOE, $3 \mathrm{M}$, and Nucon International is about to enter the Phase II effort to design and fabricate a Brayton cycle heat pump system to control an $8000 \mathrm{scfm}$ VOC air stream. Estimates from a preliminary design shows that the equipment cost and energy consumption have both been more than halved from the previous generation design at $3 \mathrm{M}$. This new and advanced system is expected to be operational 
sometime in 1992. This design will form the basis for other $3 \mathrm{M}$ facilities and other companies with similar VOC control needs to follow through with implementation of other cost competitive Brayton cycle heat pump installations.

\section{References}

(1) Heat and Liquid Recovery Using Open Cycle Heat Pump System, Bryce Fox, 3M; U.S. Patent \#4,295,282, Dated October 20, 1981

(2) Vapor Recovery Method and Apparatus, Leslie R. Flink, Bryce J. Fox, Mary K. Witzel, 3M U.S. Patent \#4,480,393, Dated November 6, 1984

(3) Heat and Liquid Recovery Using Open Cycle Heat Pump System Bryce J. Fox, 3M; U.S. Patent \#4,539,816, Dated September 10, 1985

(4) Full Size Industrial Application of the Brayton Cycle Heat Pump in Adsorption Concentrator, J. L. Kovach, 1989 ASME Winter Annual Meeting, AES-Volume 8 (Advances in Industrial Heat Pumps Technology - 1989). December, 1989 


\section{APPENDIXA}

Weatherford Brayton cycle solvent recovery system:

Weatherford solvent recovery system is based on BCHP solvent recovery process using free spindle turbo compressors. This system was designed and fabricated by Nucon. Solvent is methyl ethyl ketone and toluene.

This appendix contains four P \& ID drawings and a system component list. 


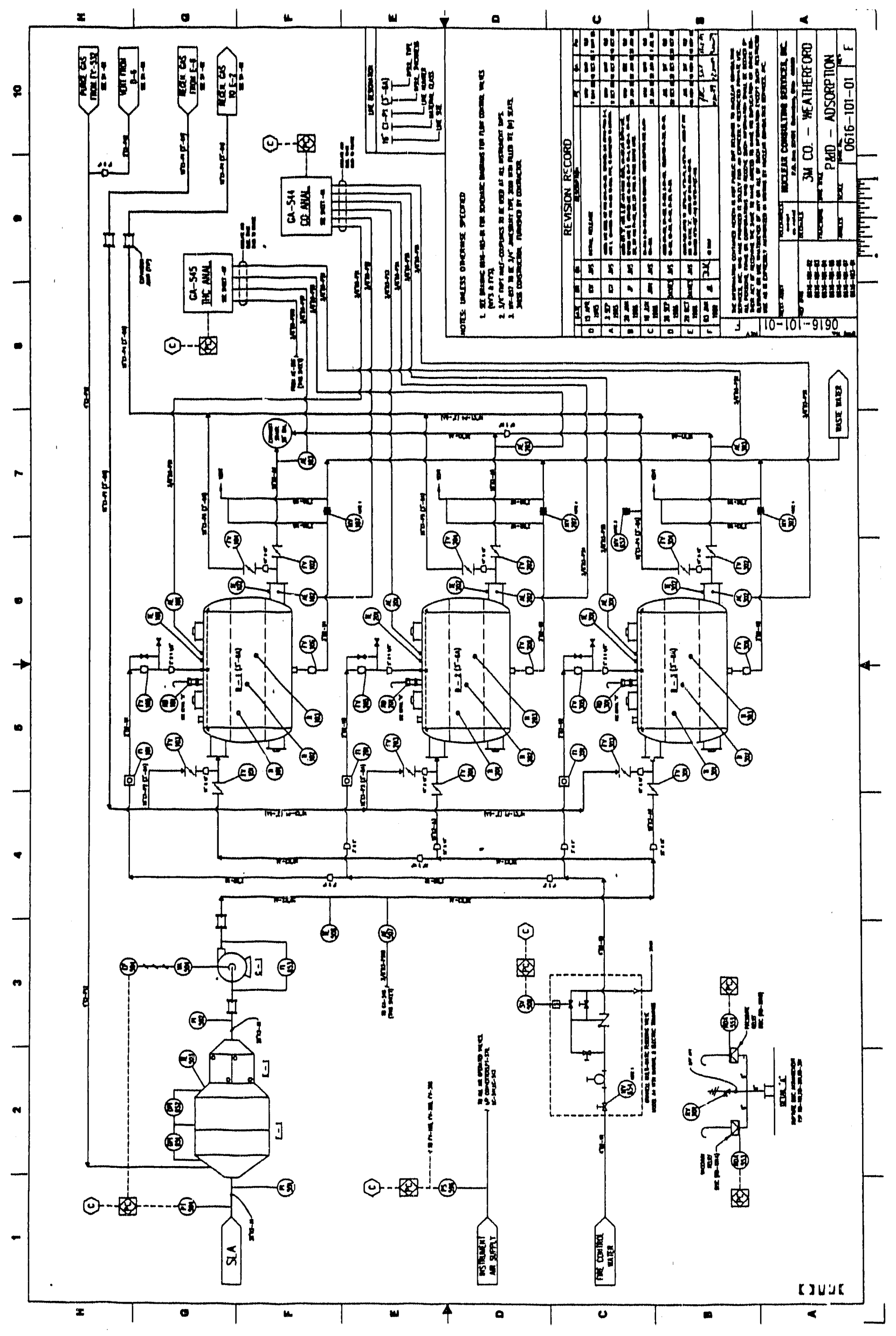




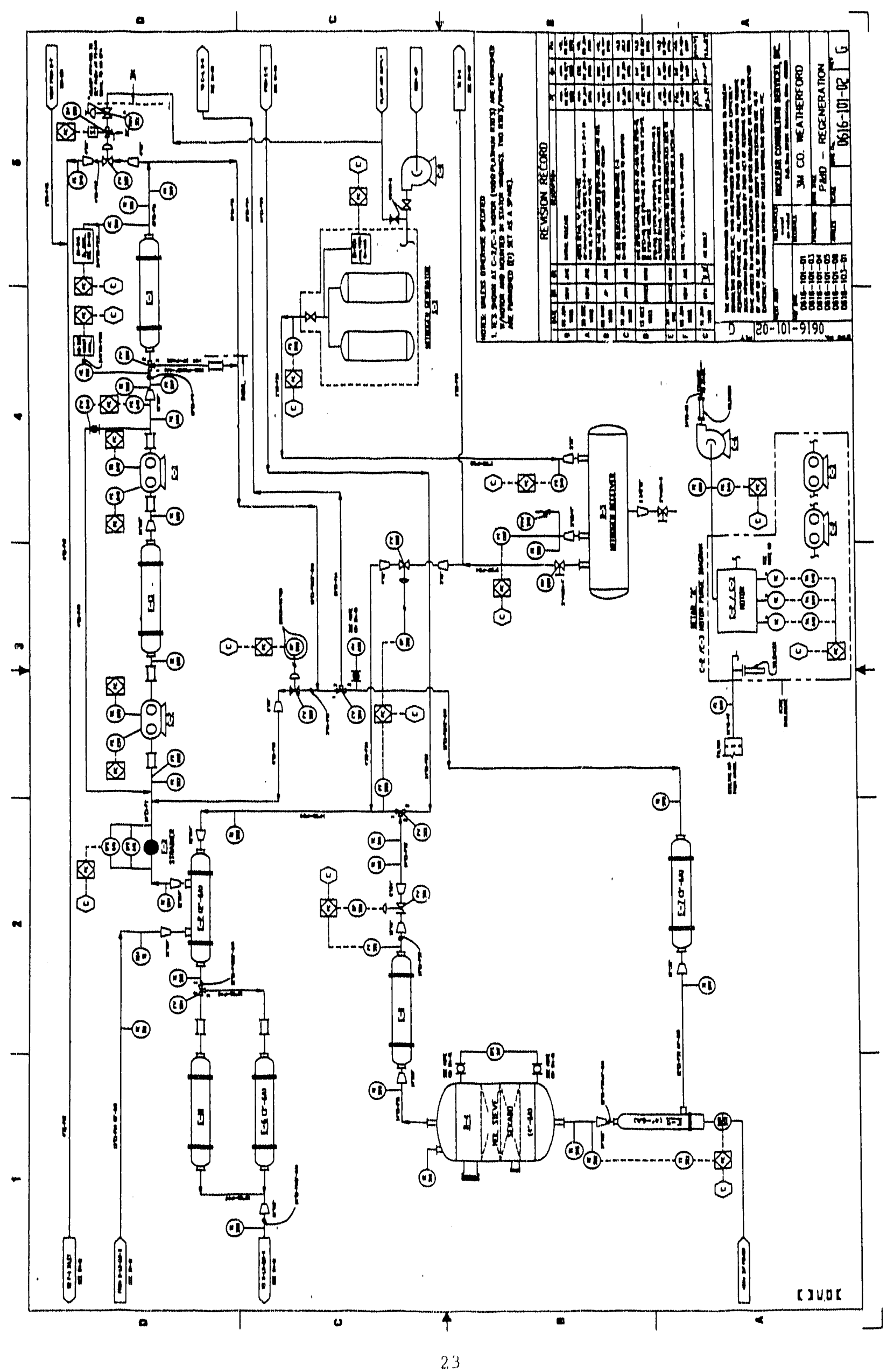




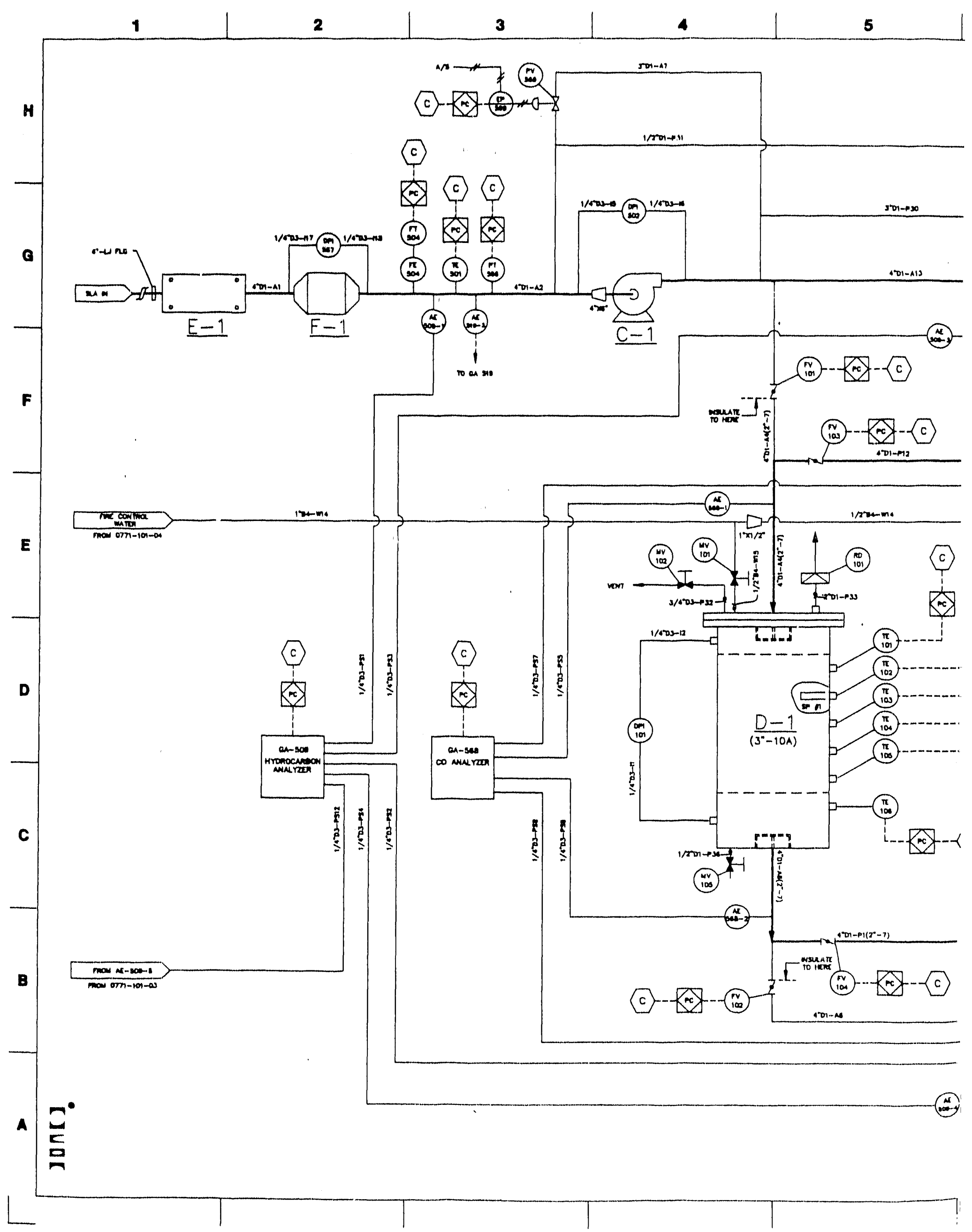




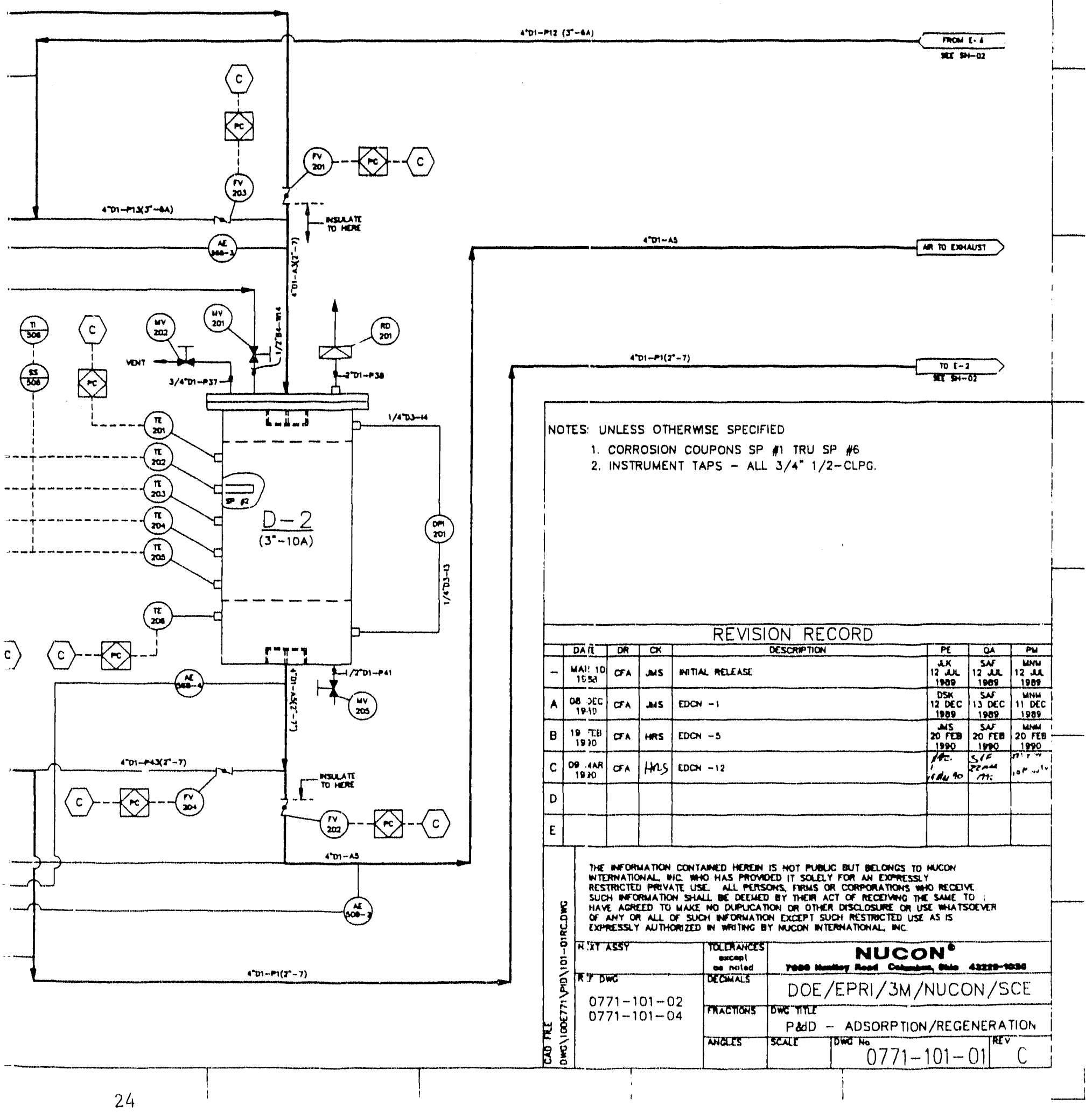




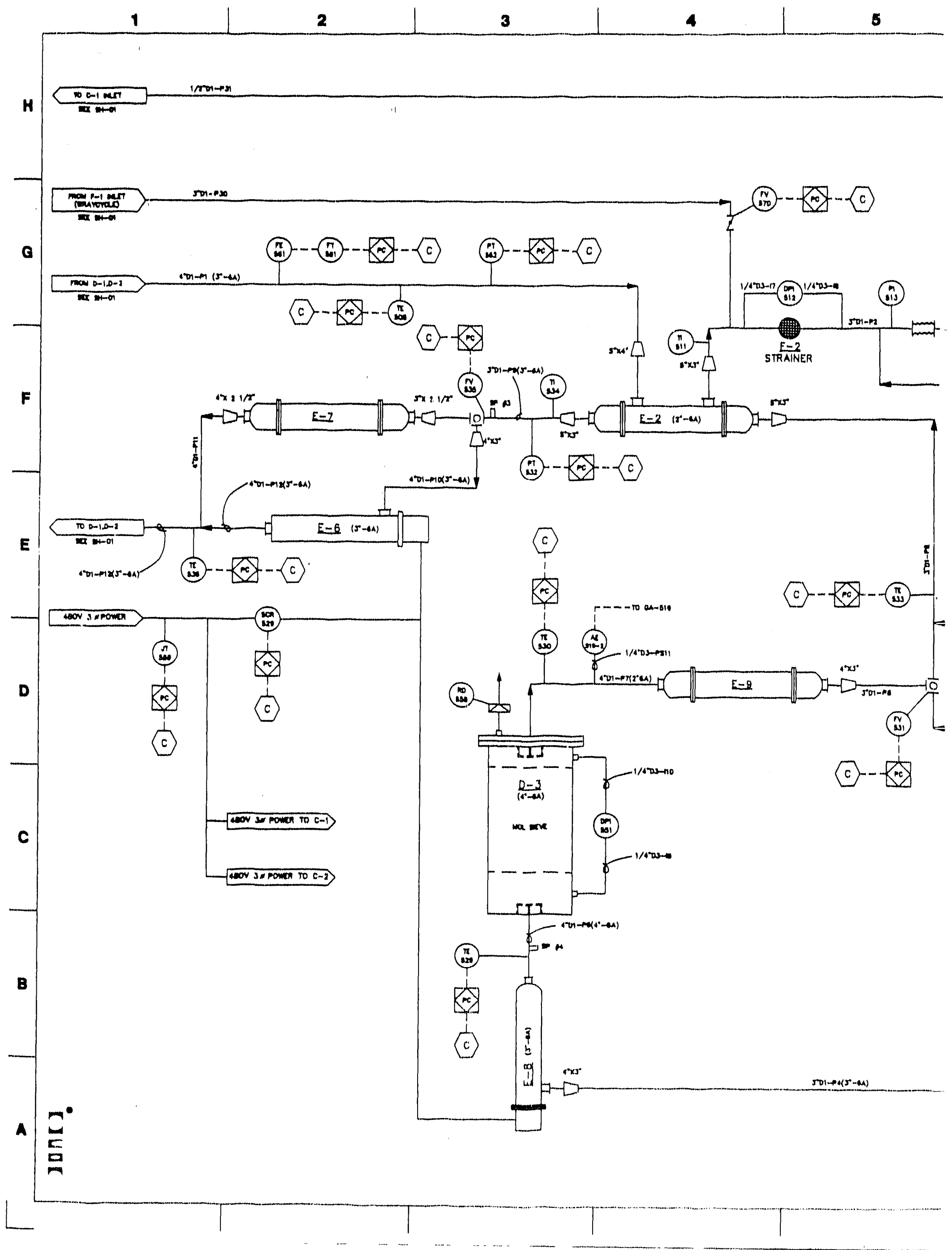




\begin{tabular}{l|l|l|l|l}
6 & 7 & 8 & 9 & 10 \\
\hline
\end{tabular}

$\operatorname{lnow-as|}$

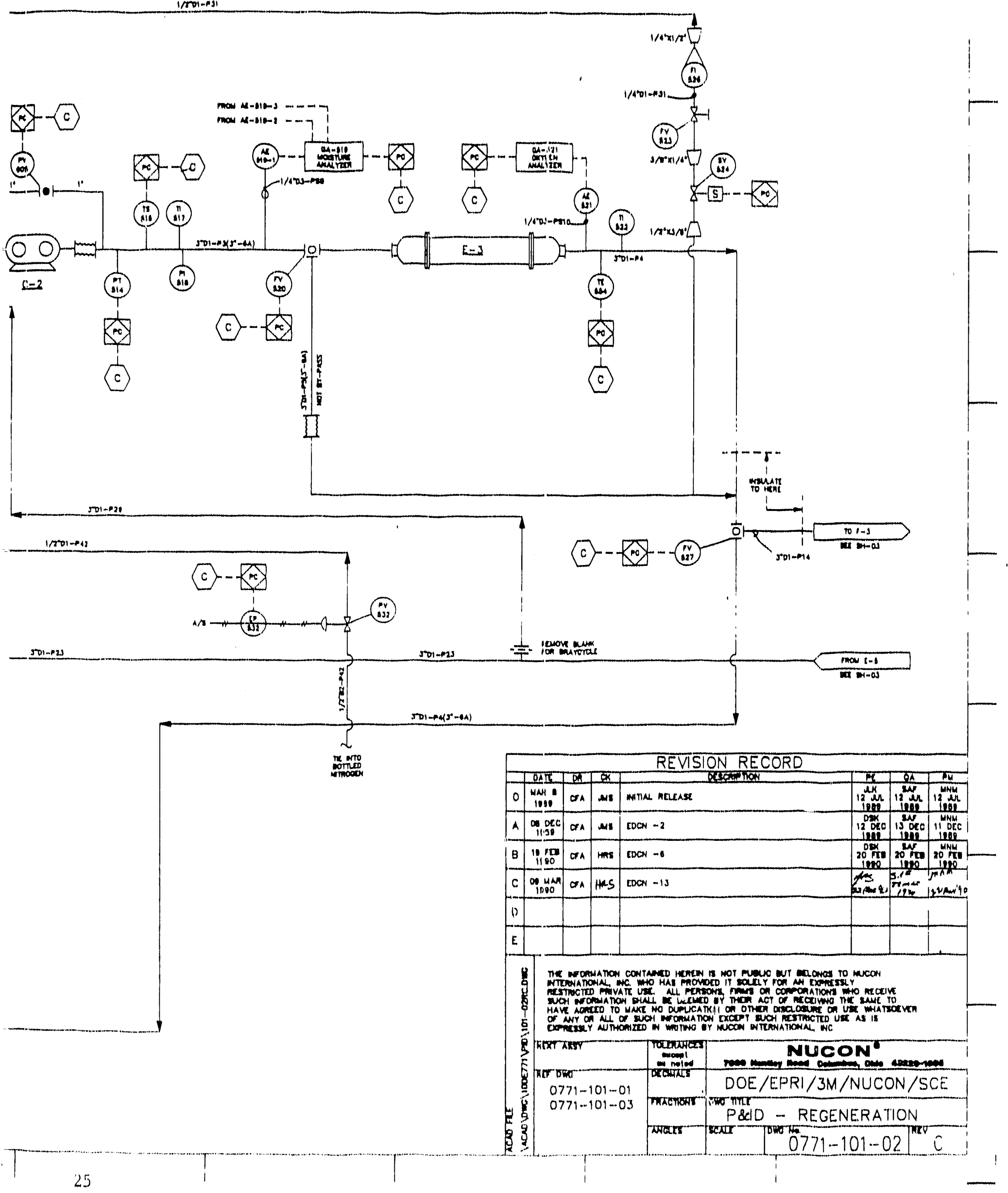




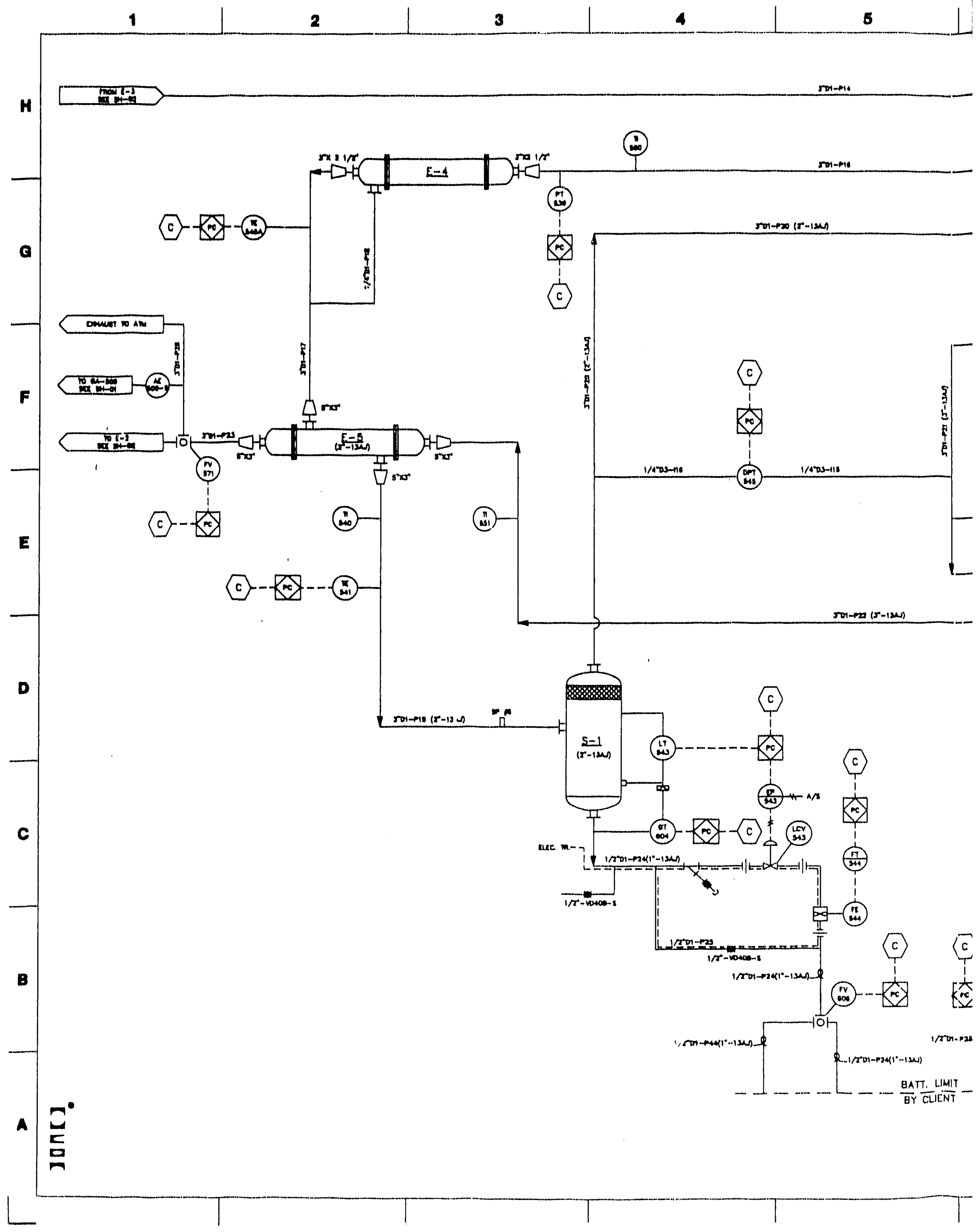




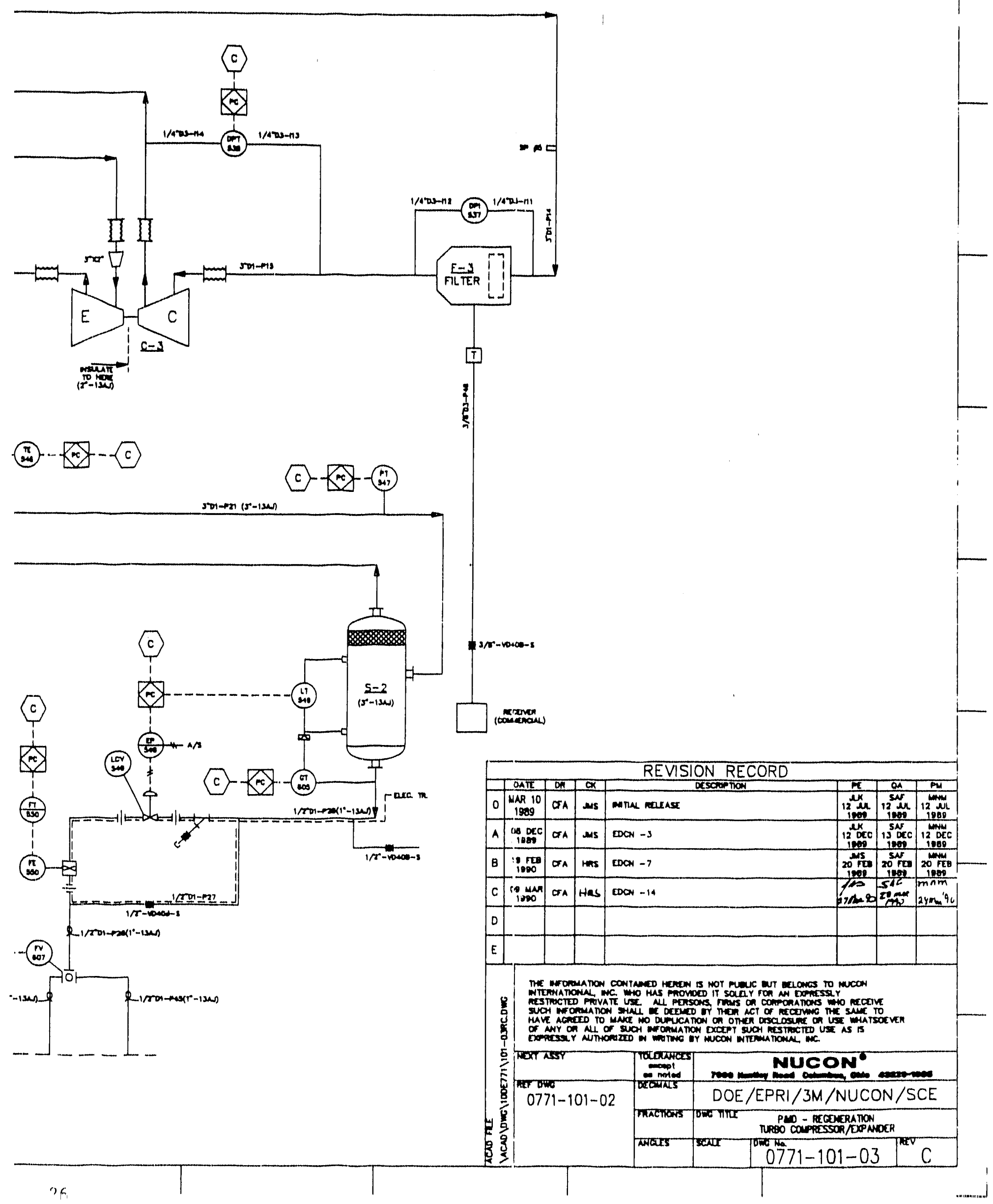




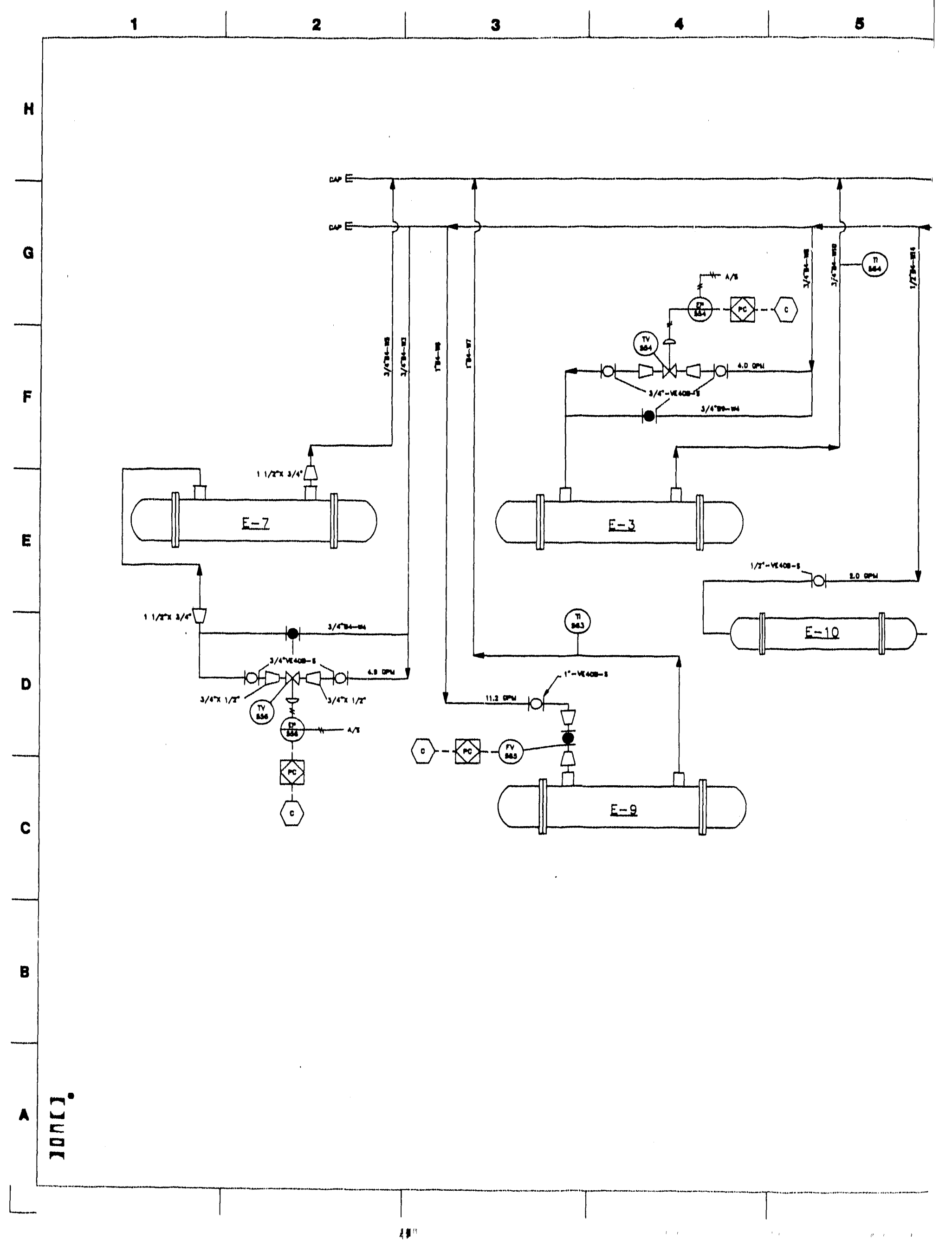




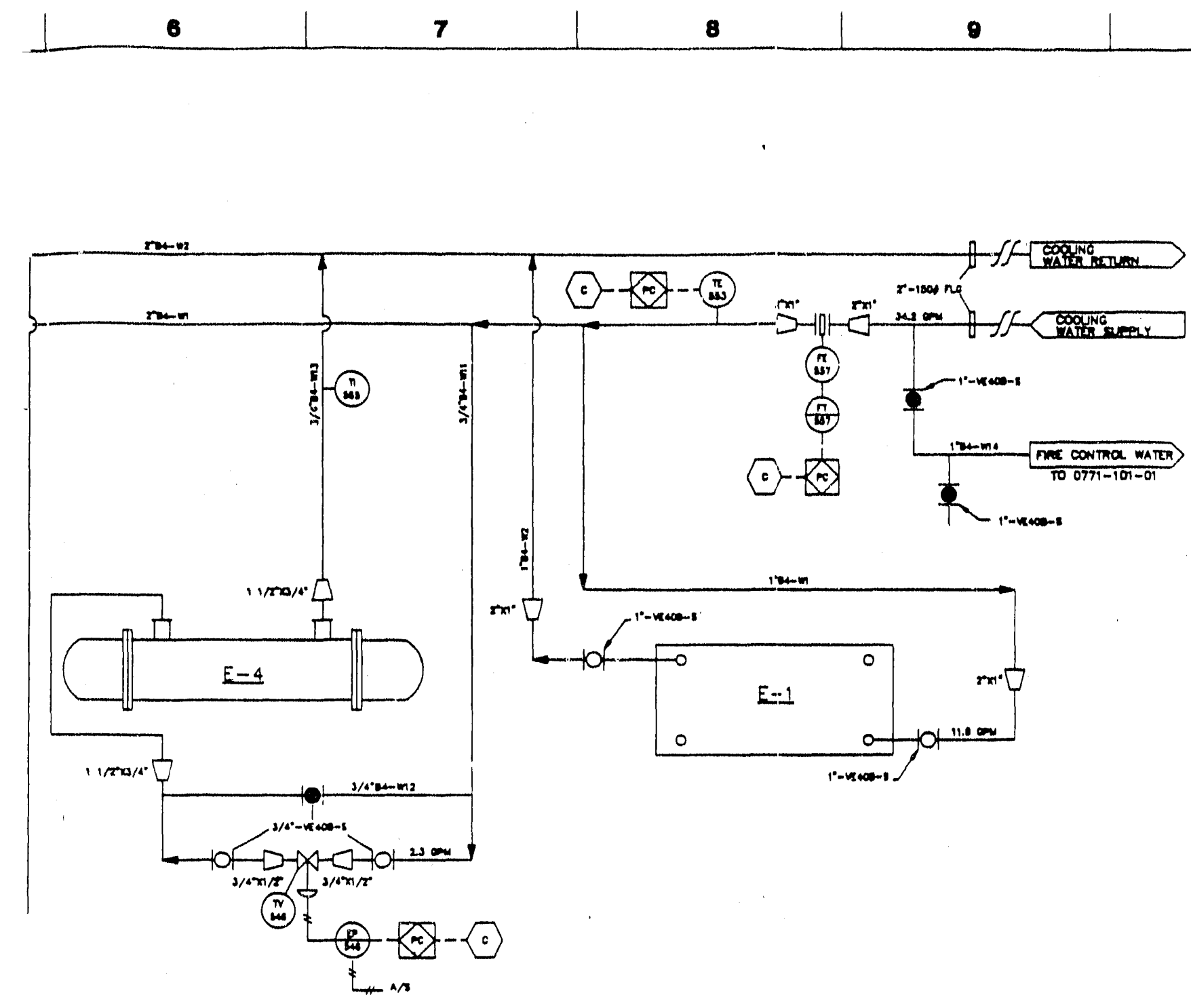

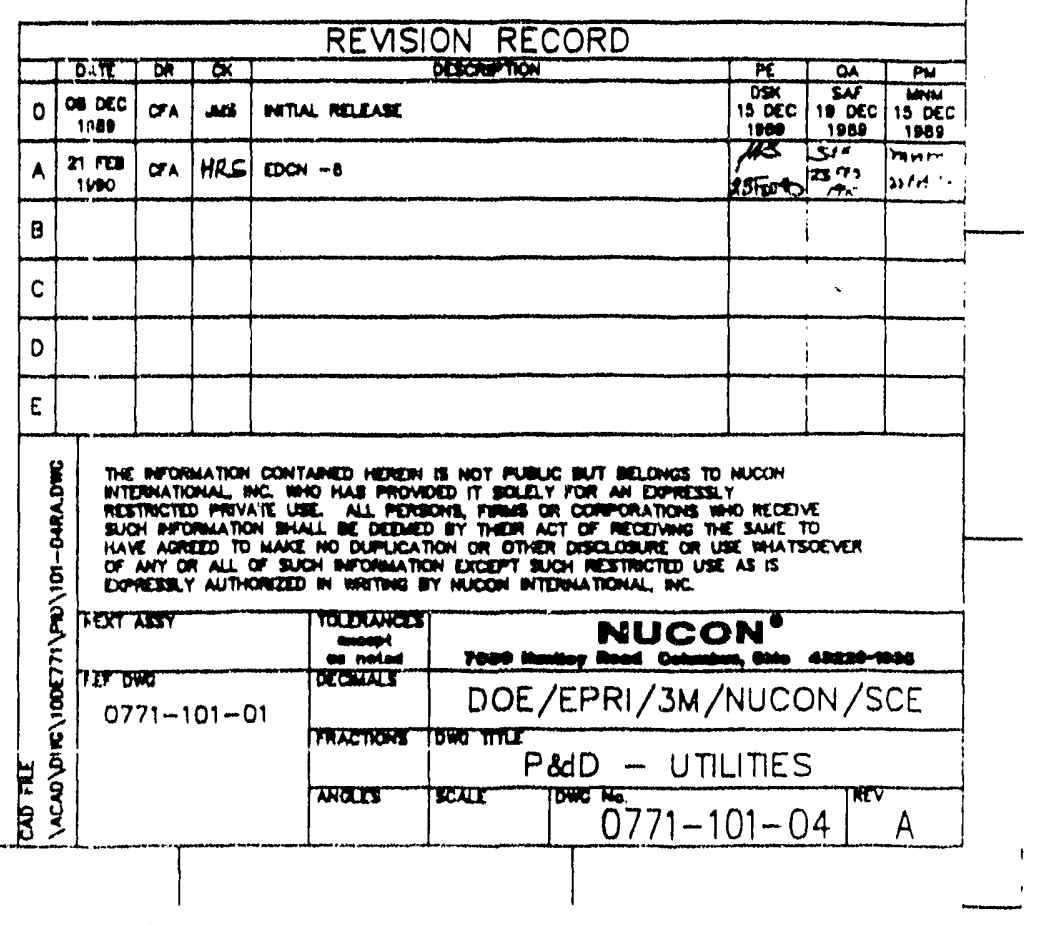




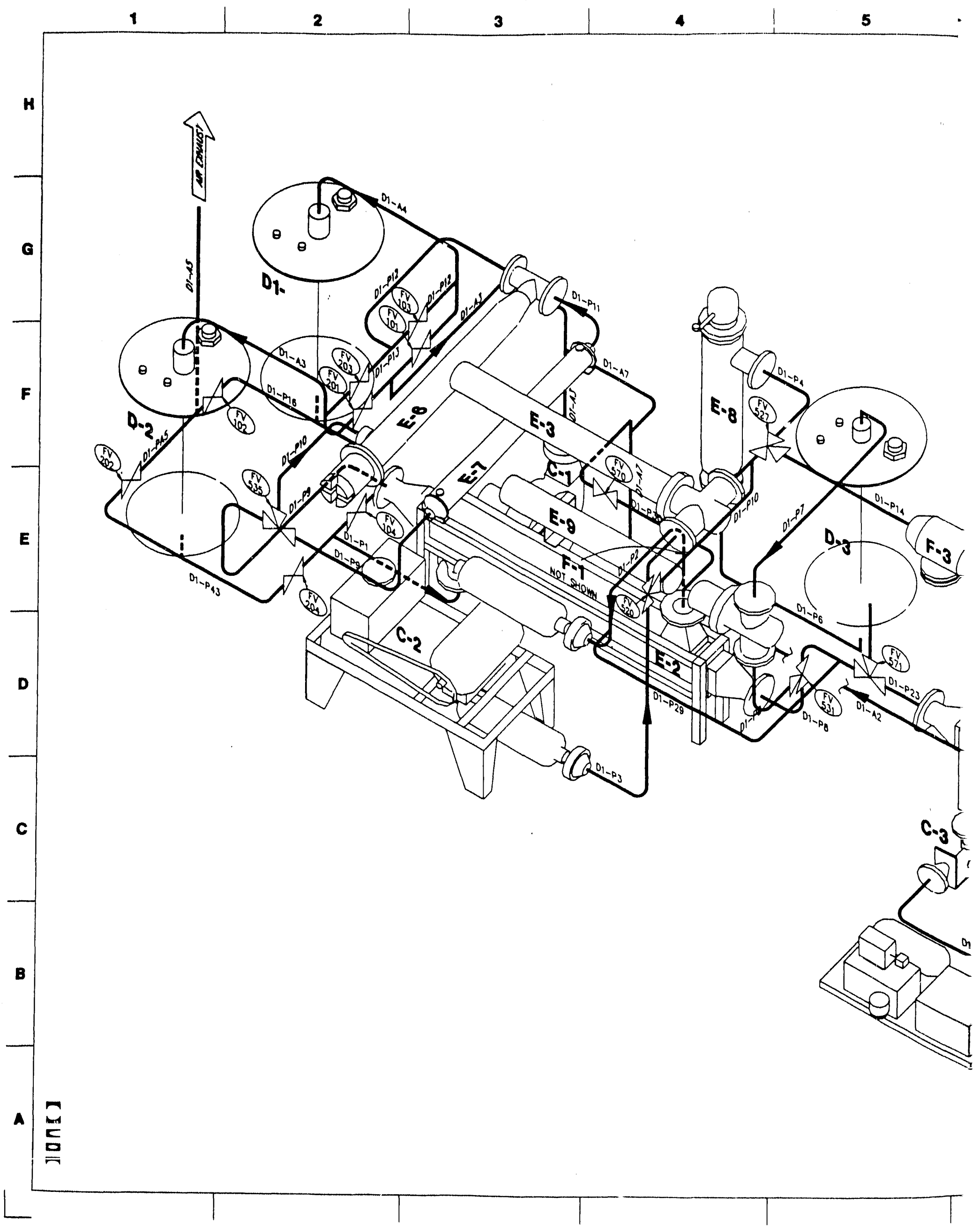




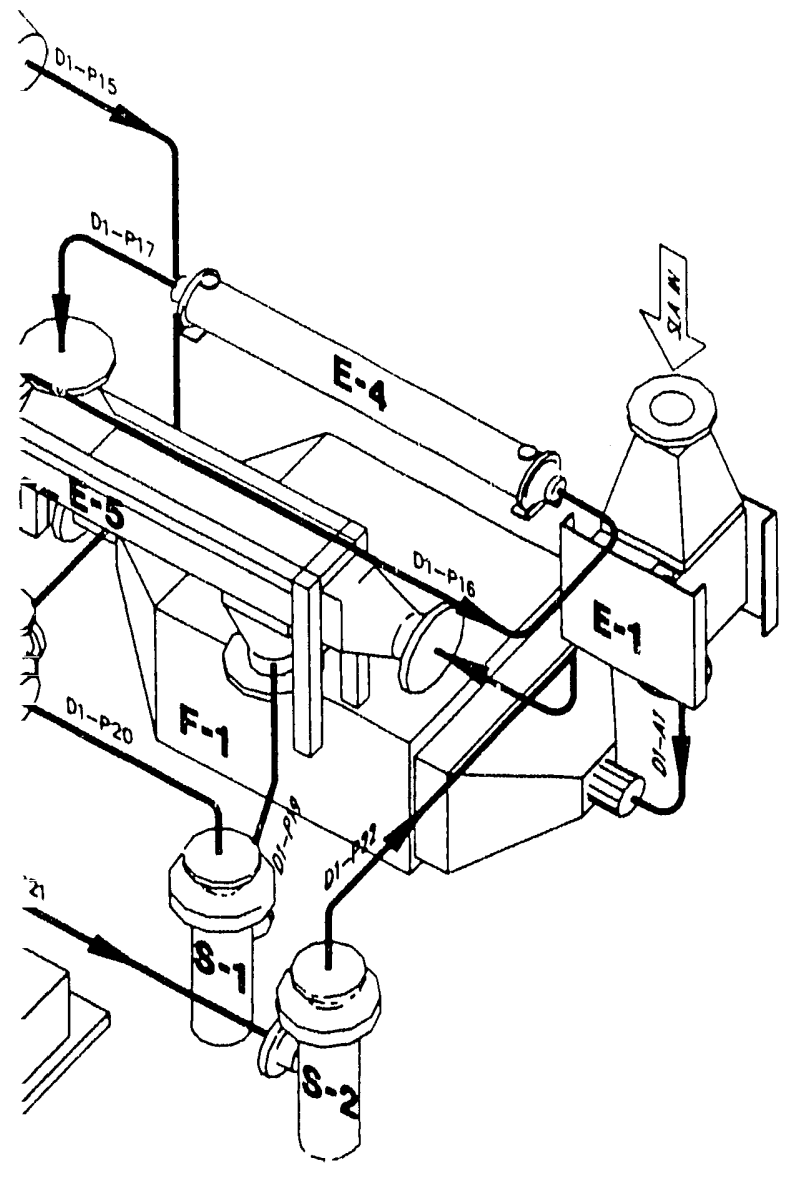

NOTES: UNLESS OTHERMSE SPECIFIED

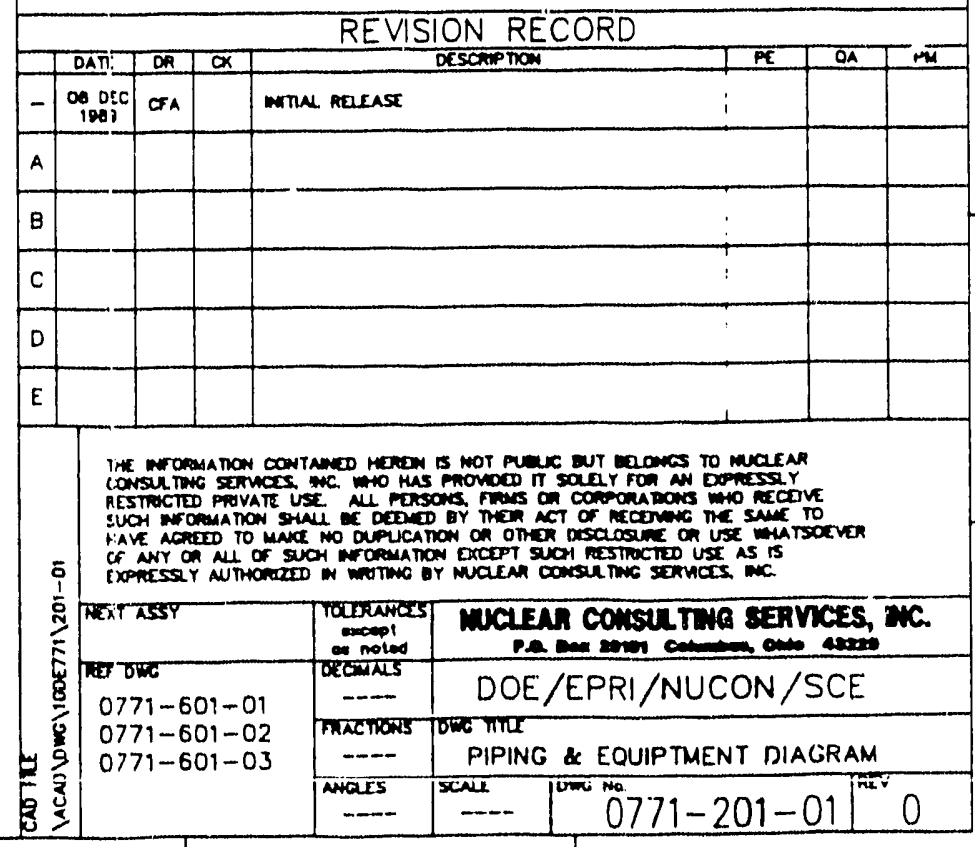




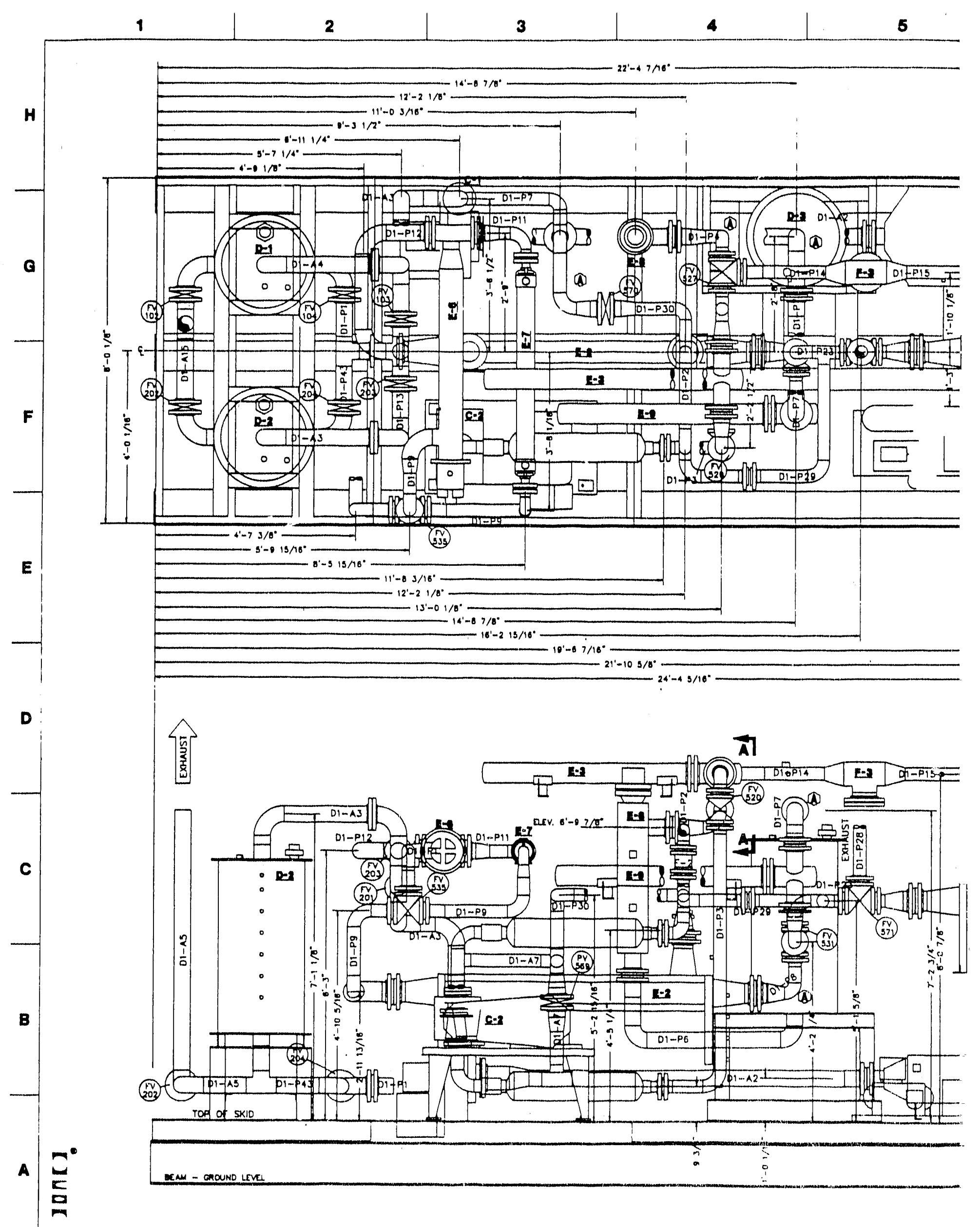



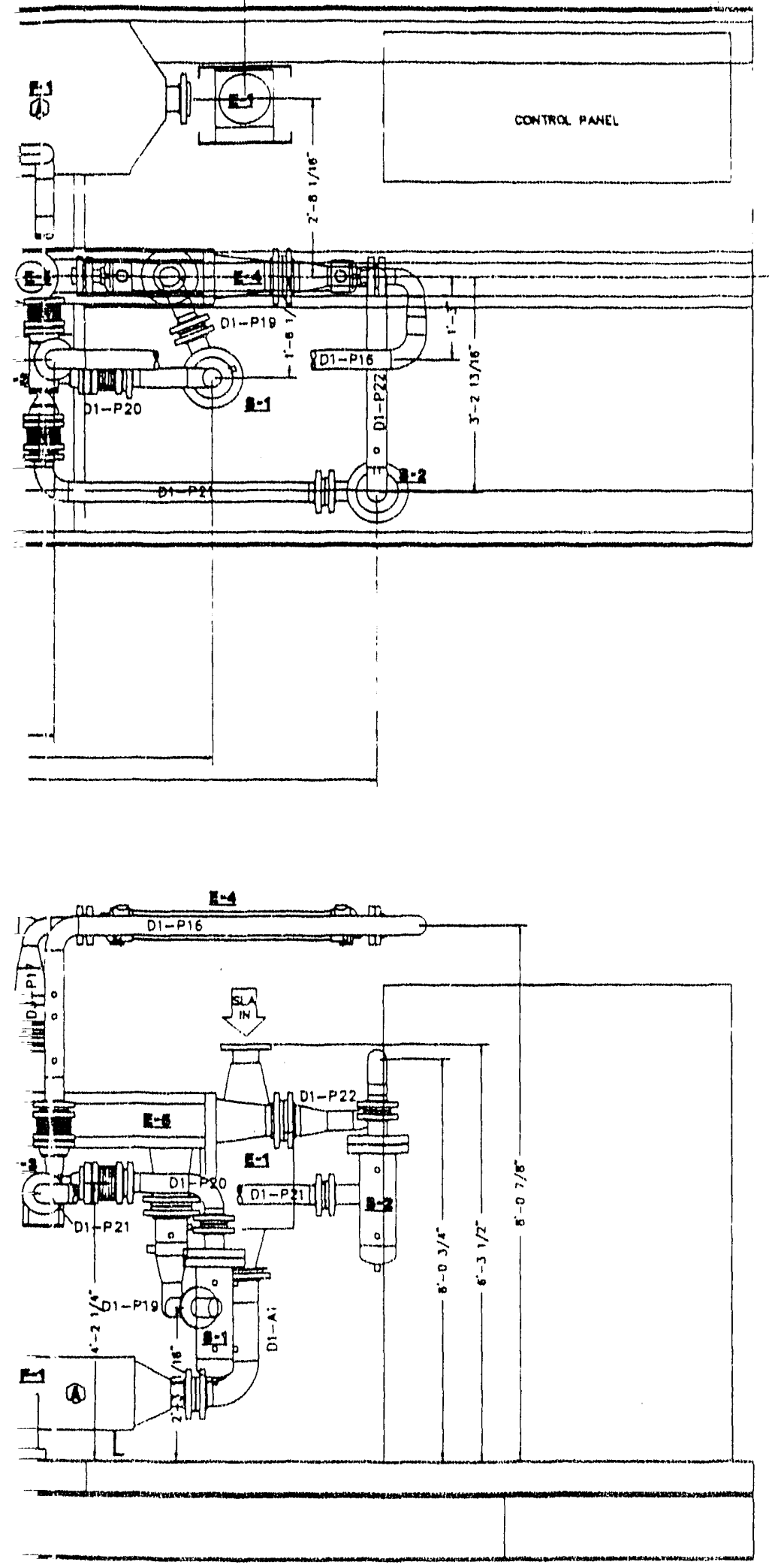


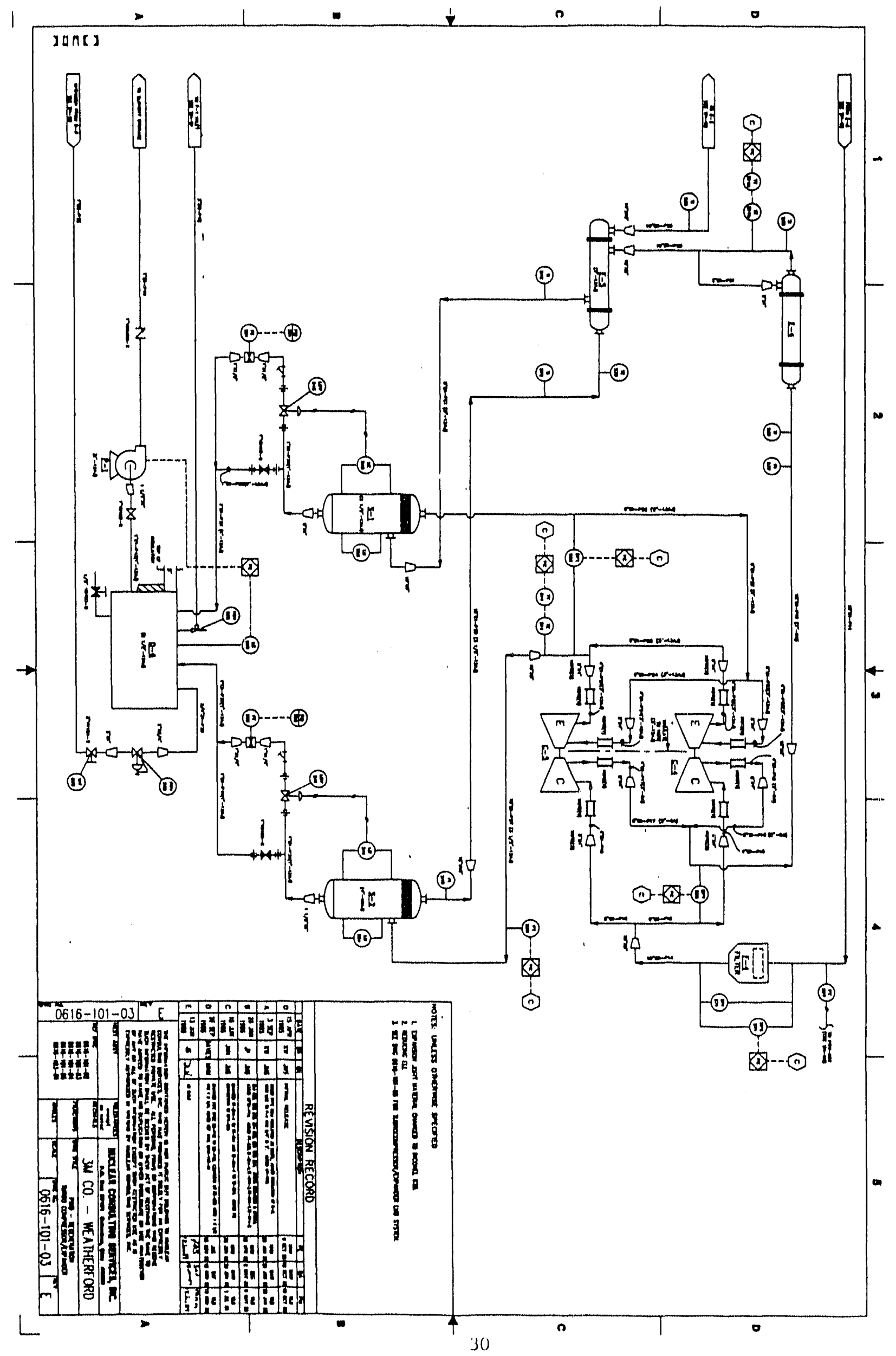




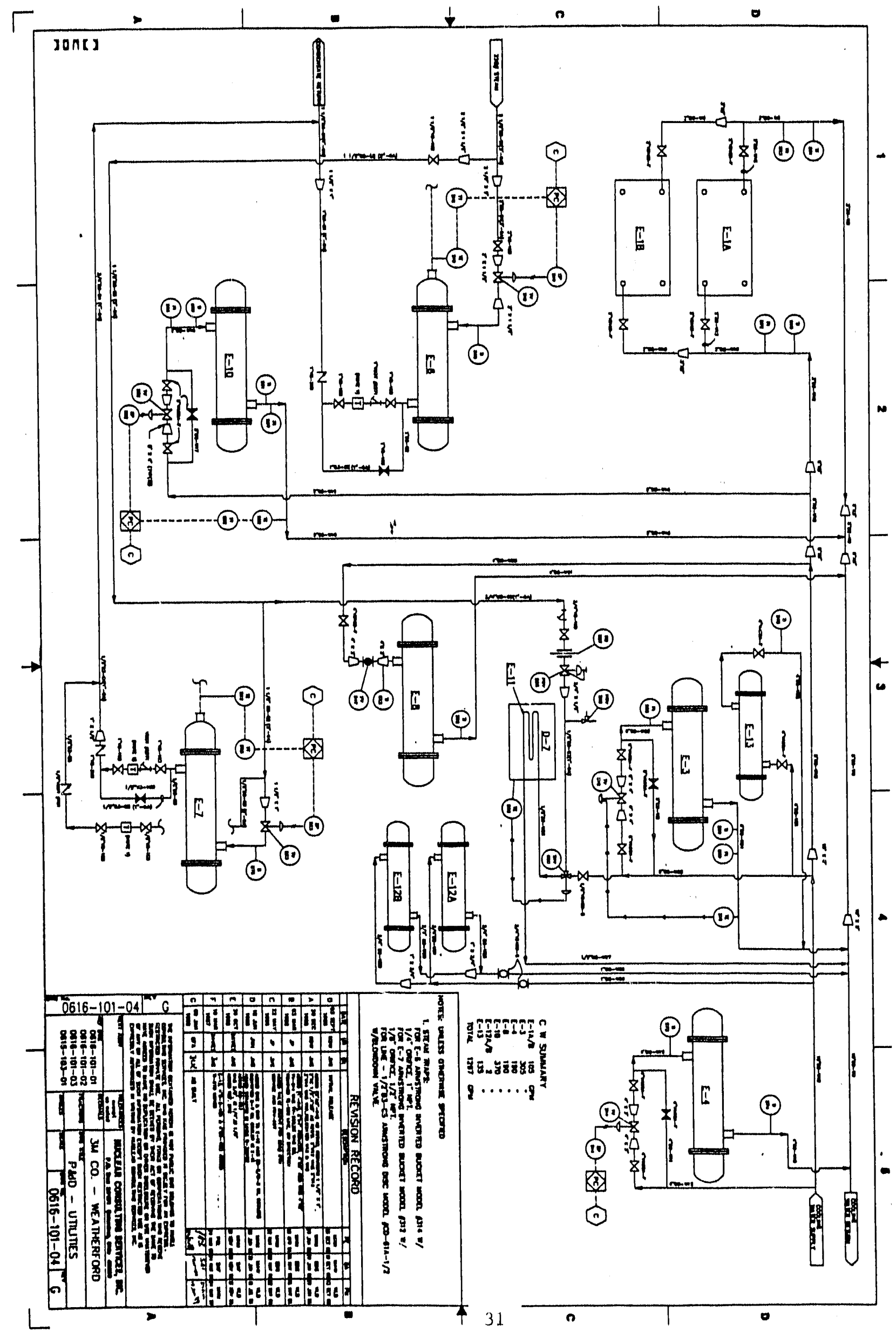




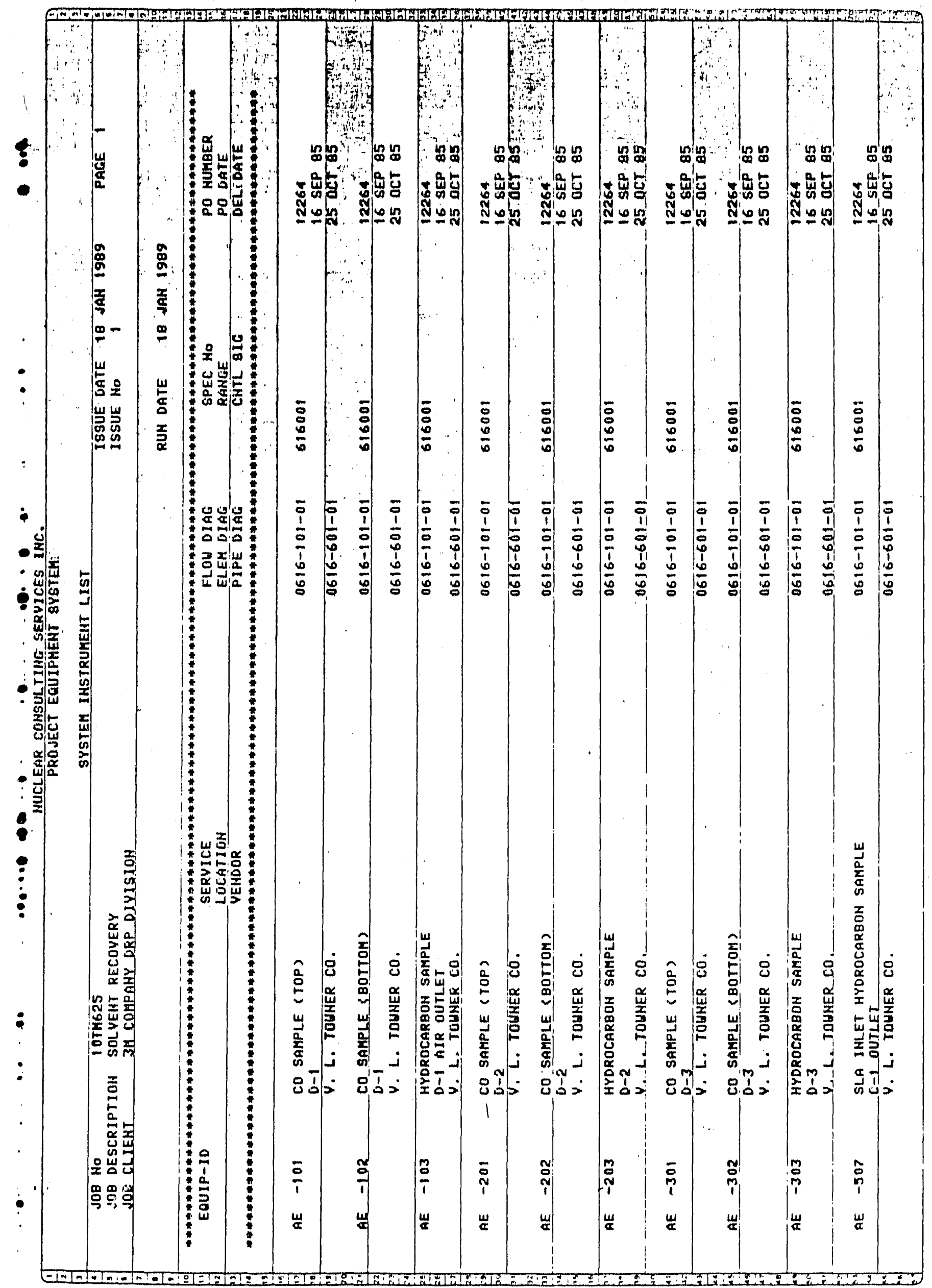




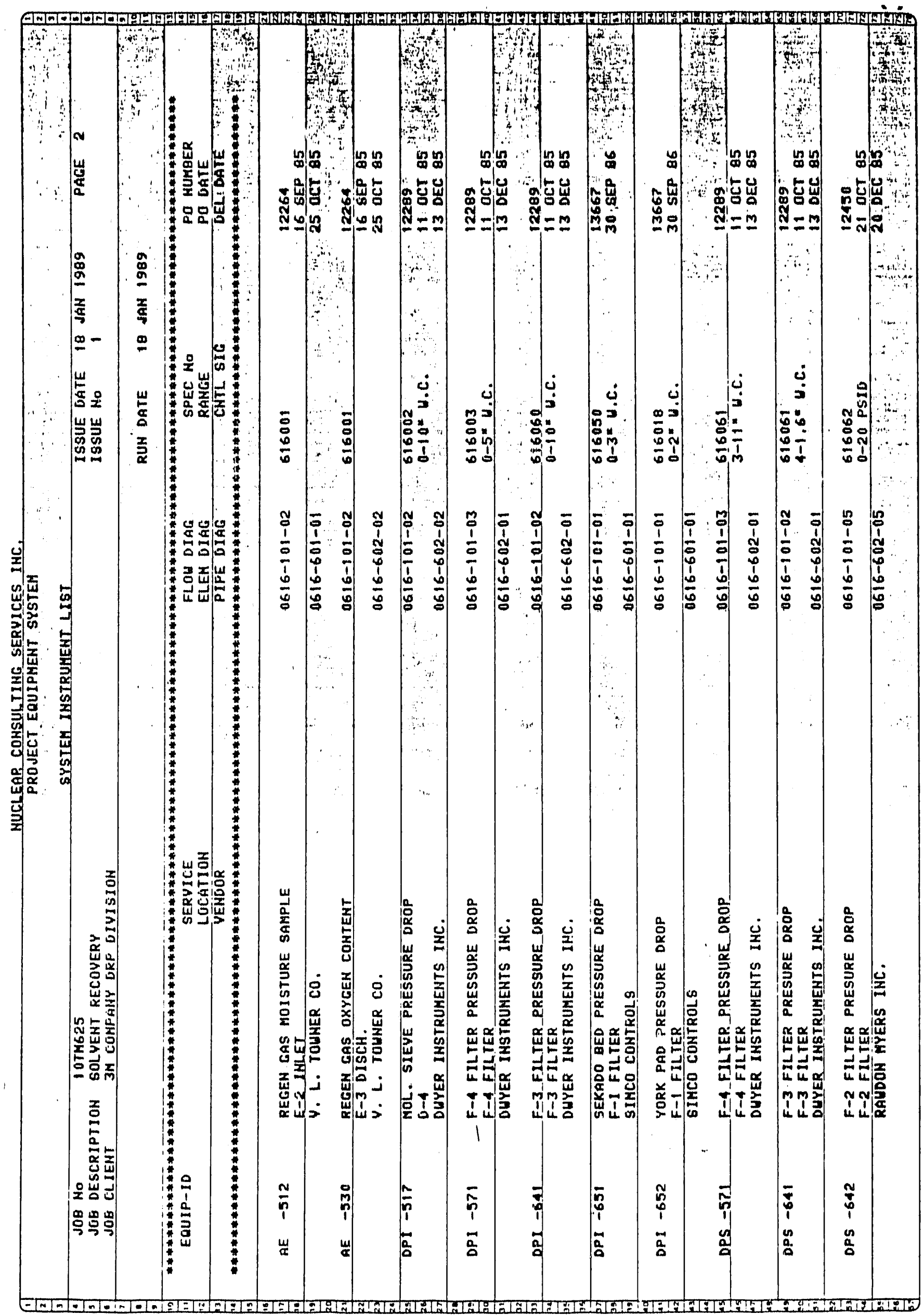




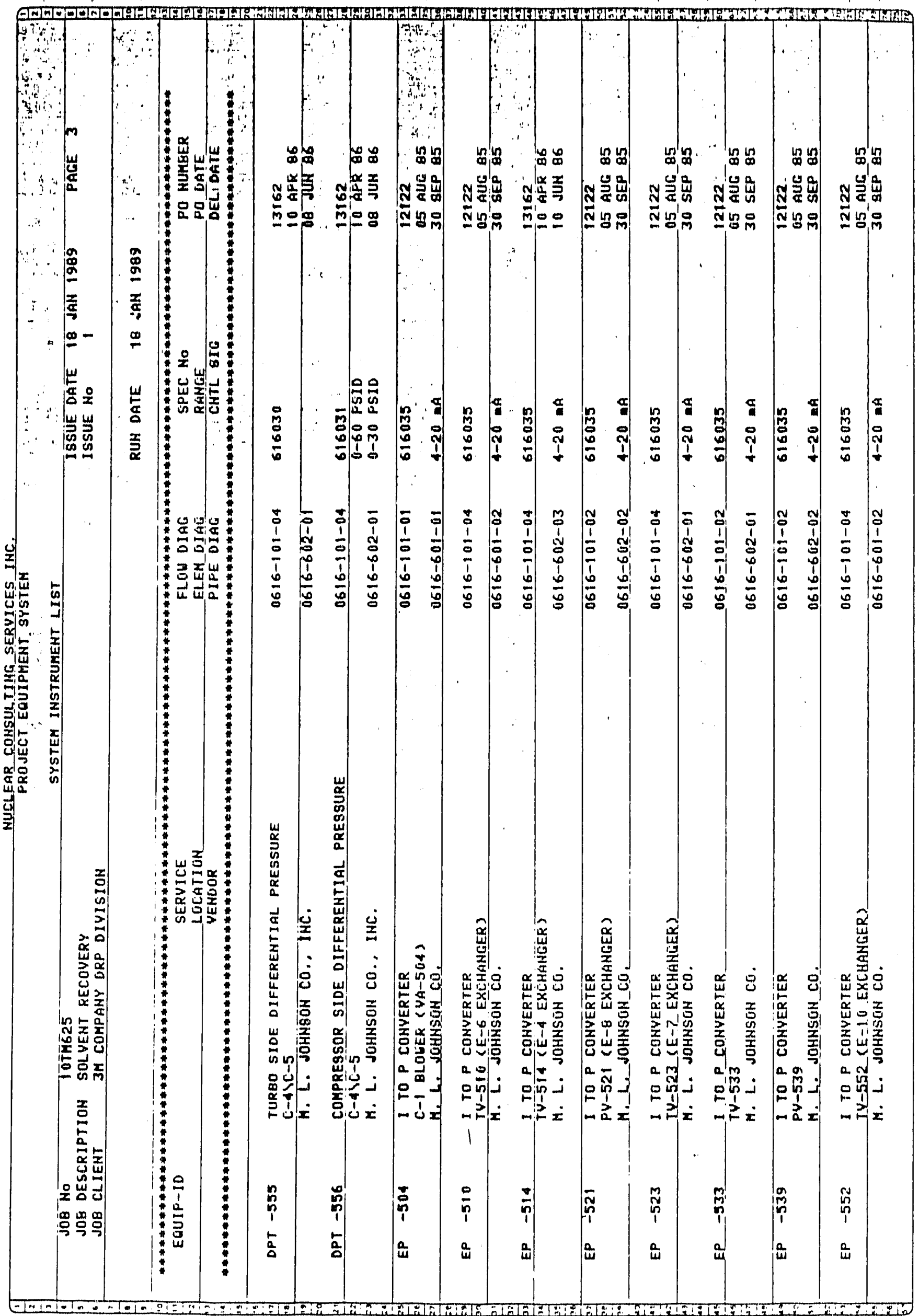




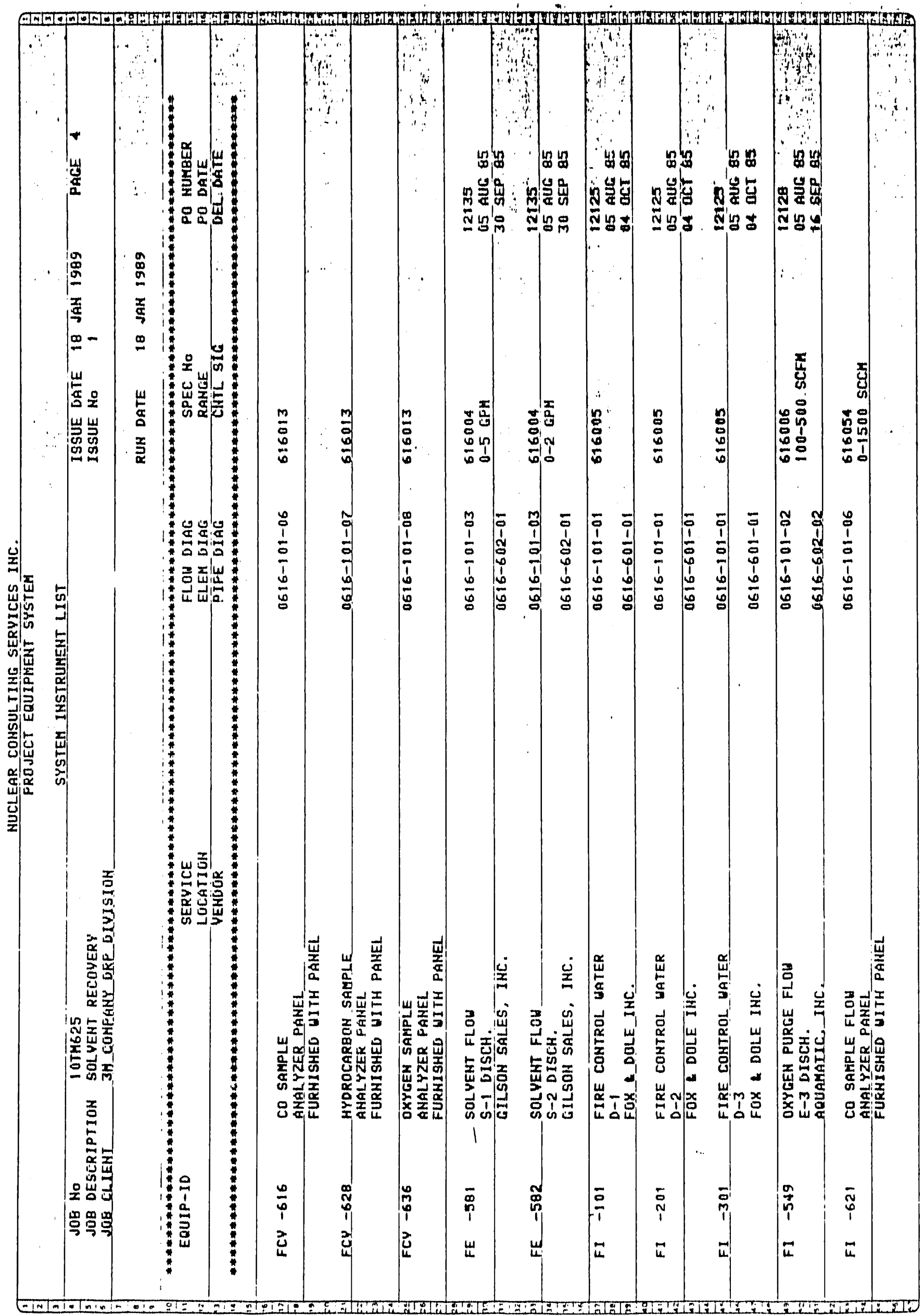




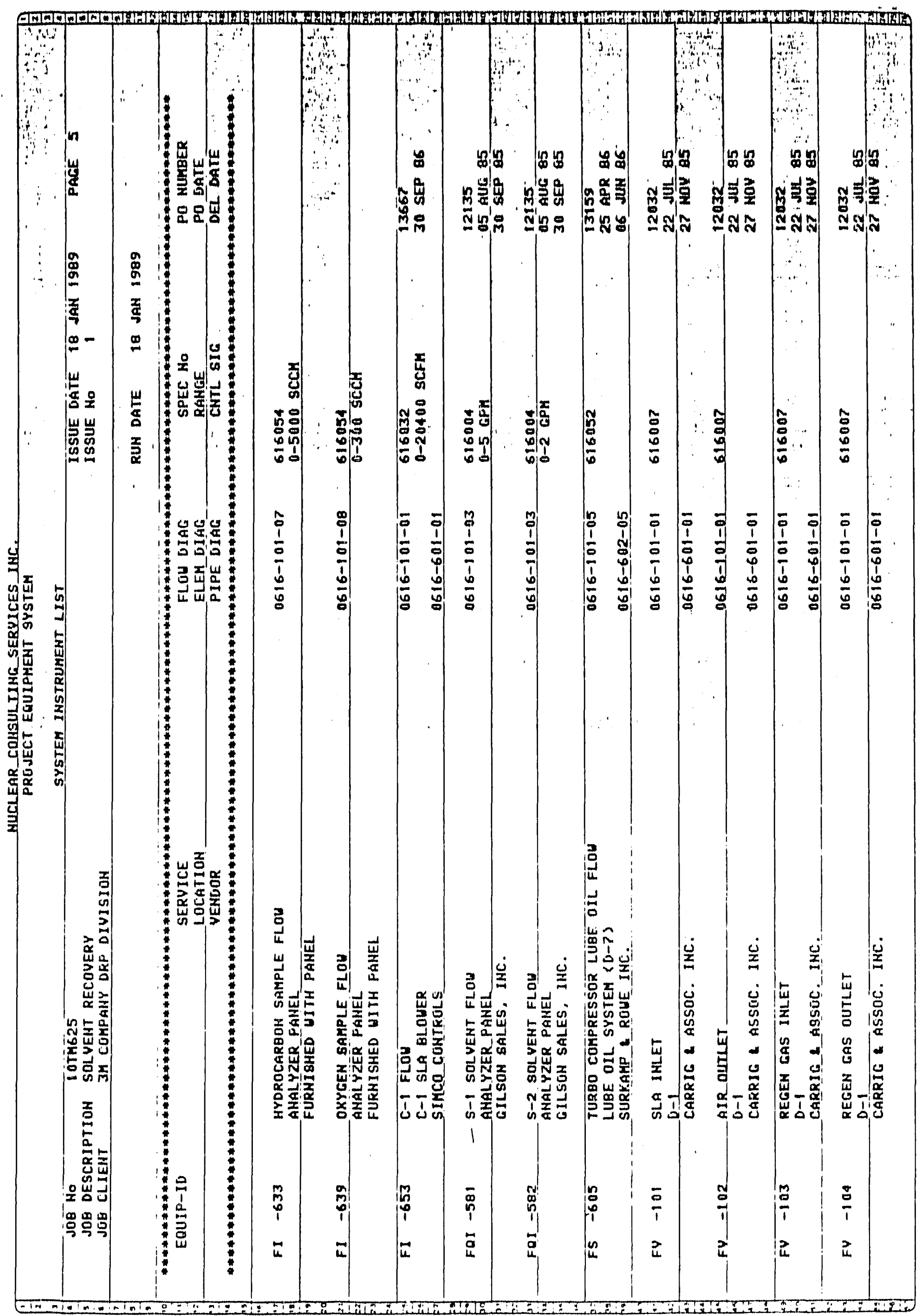




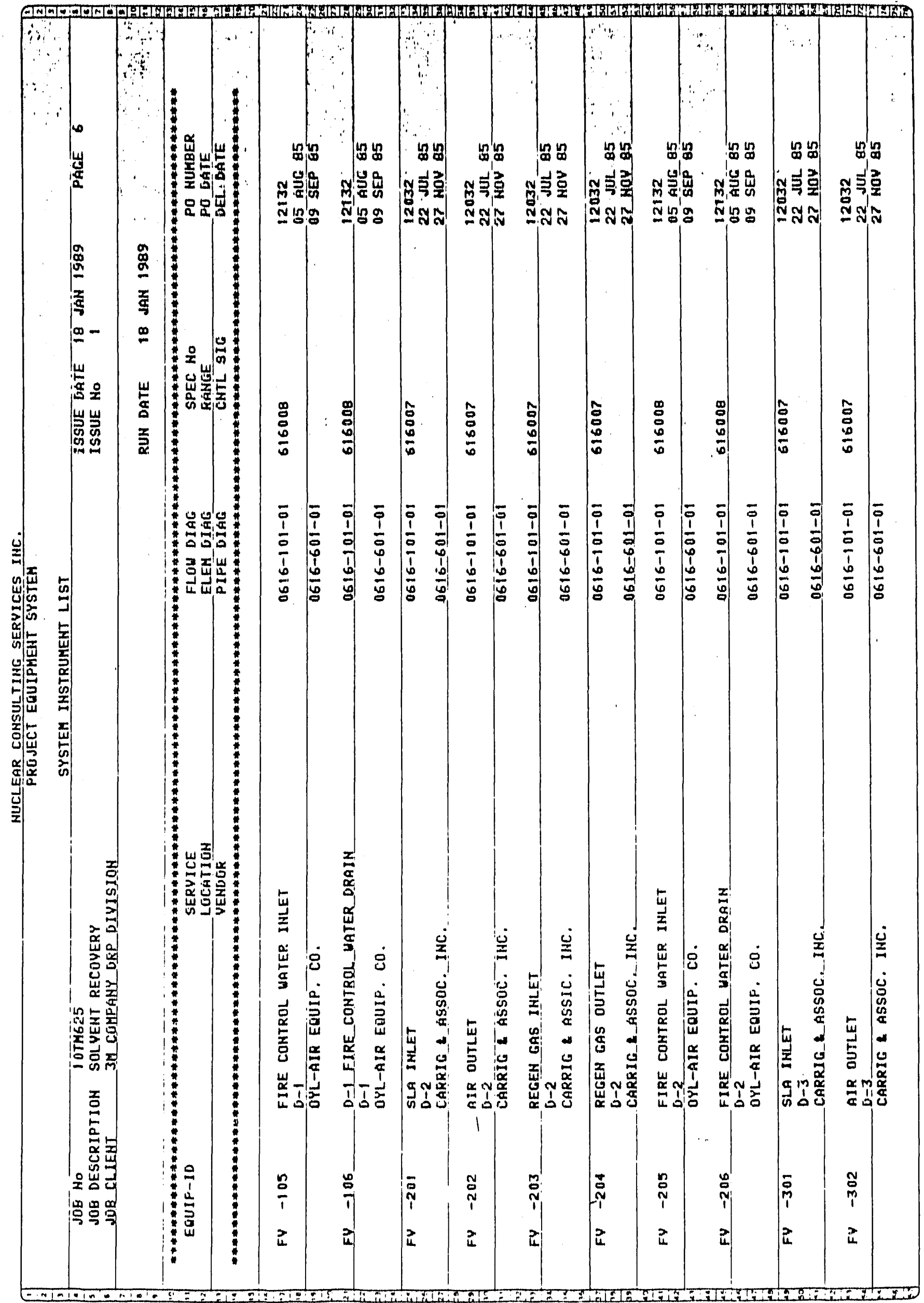




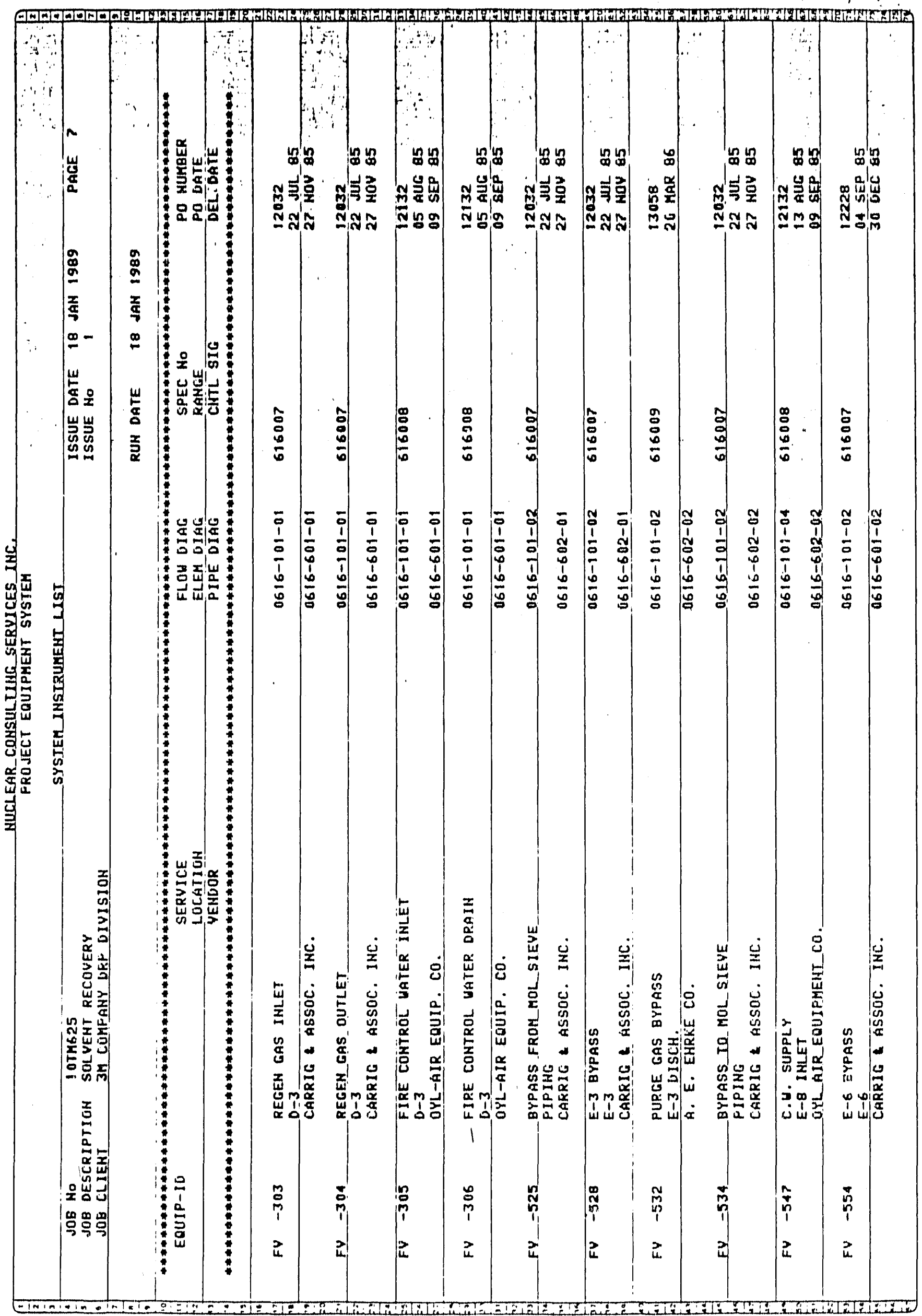




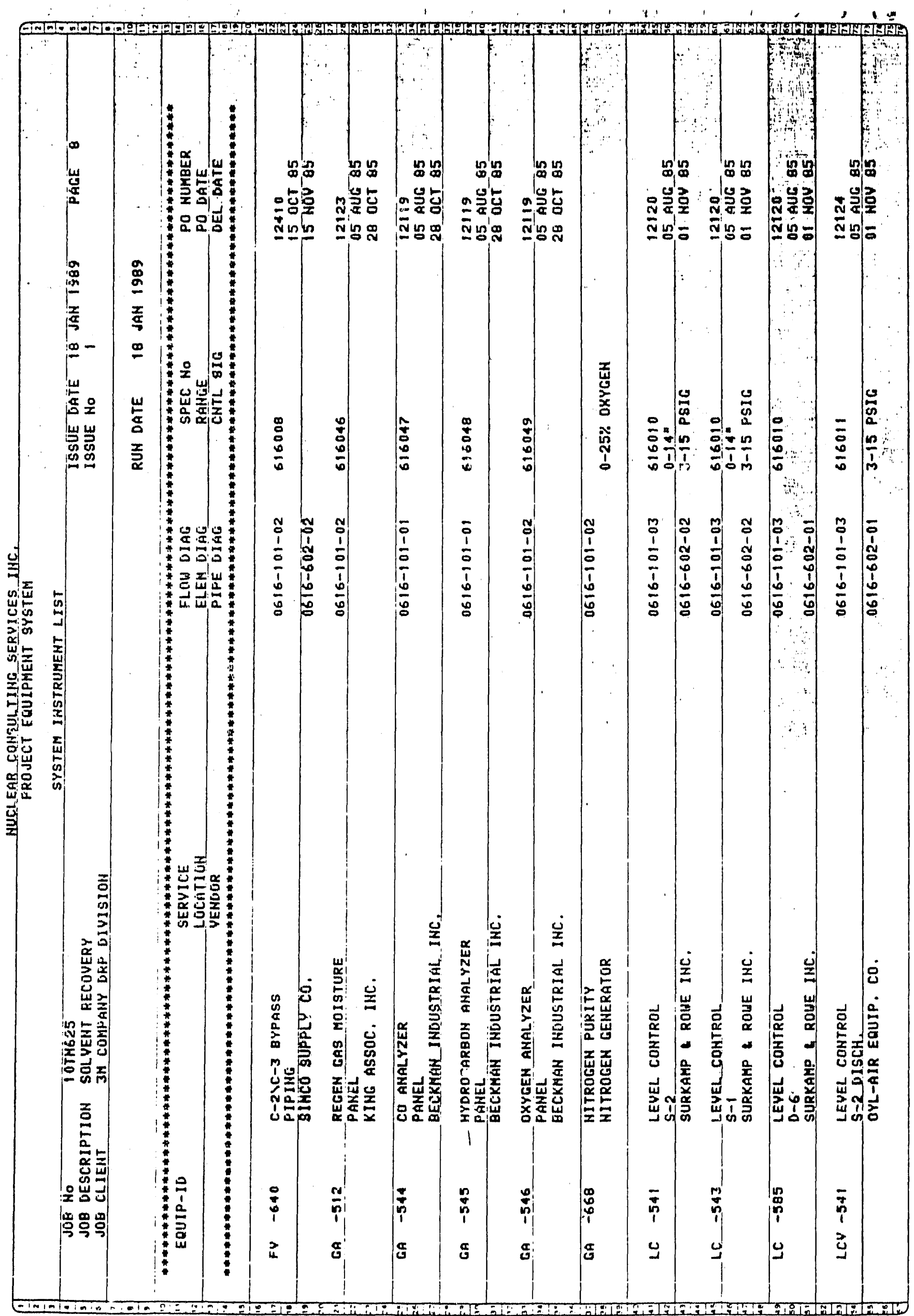




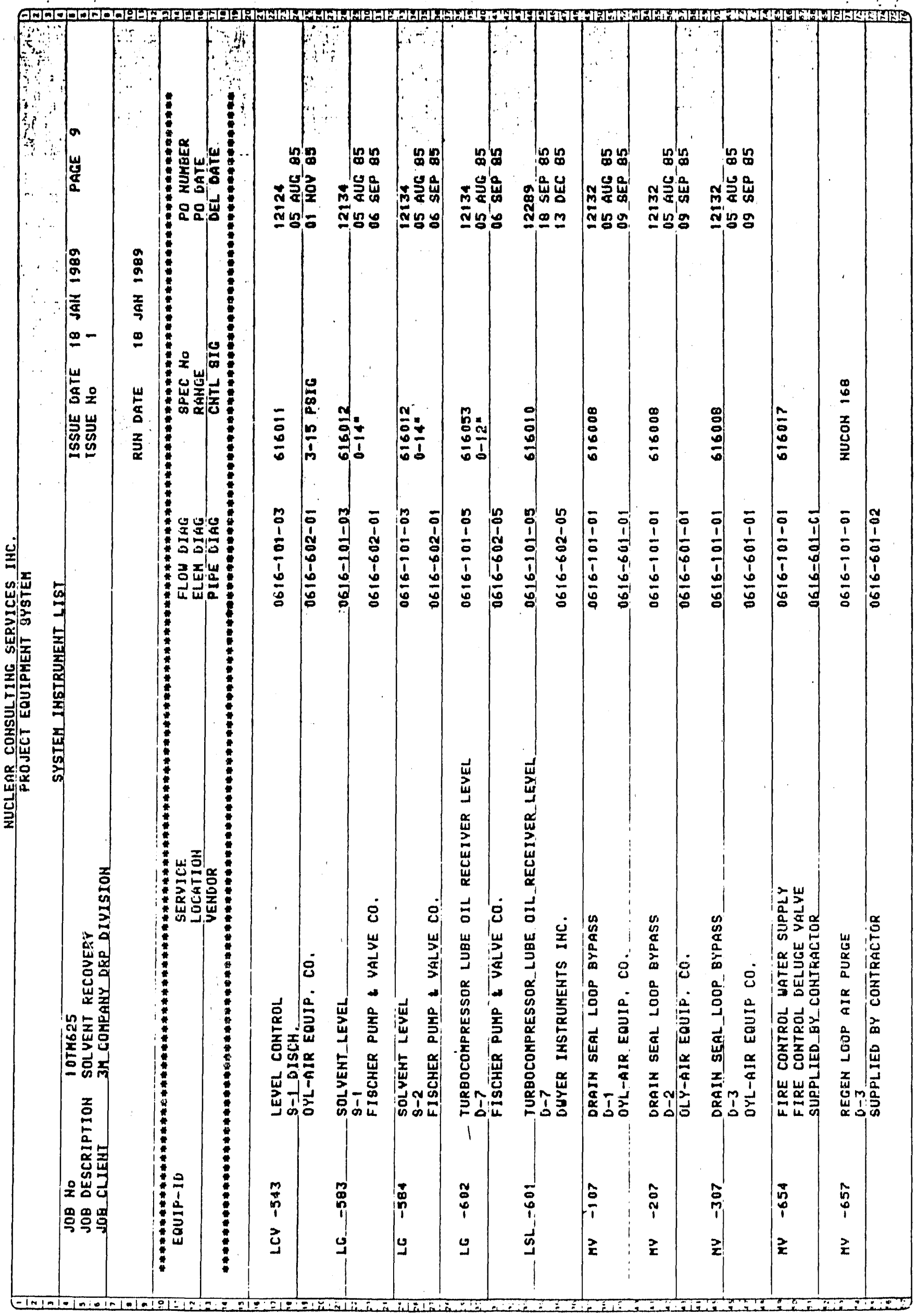




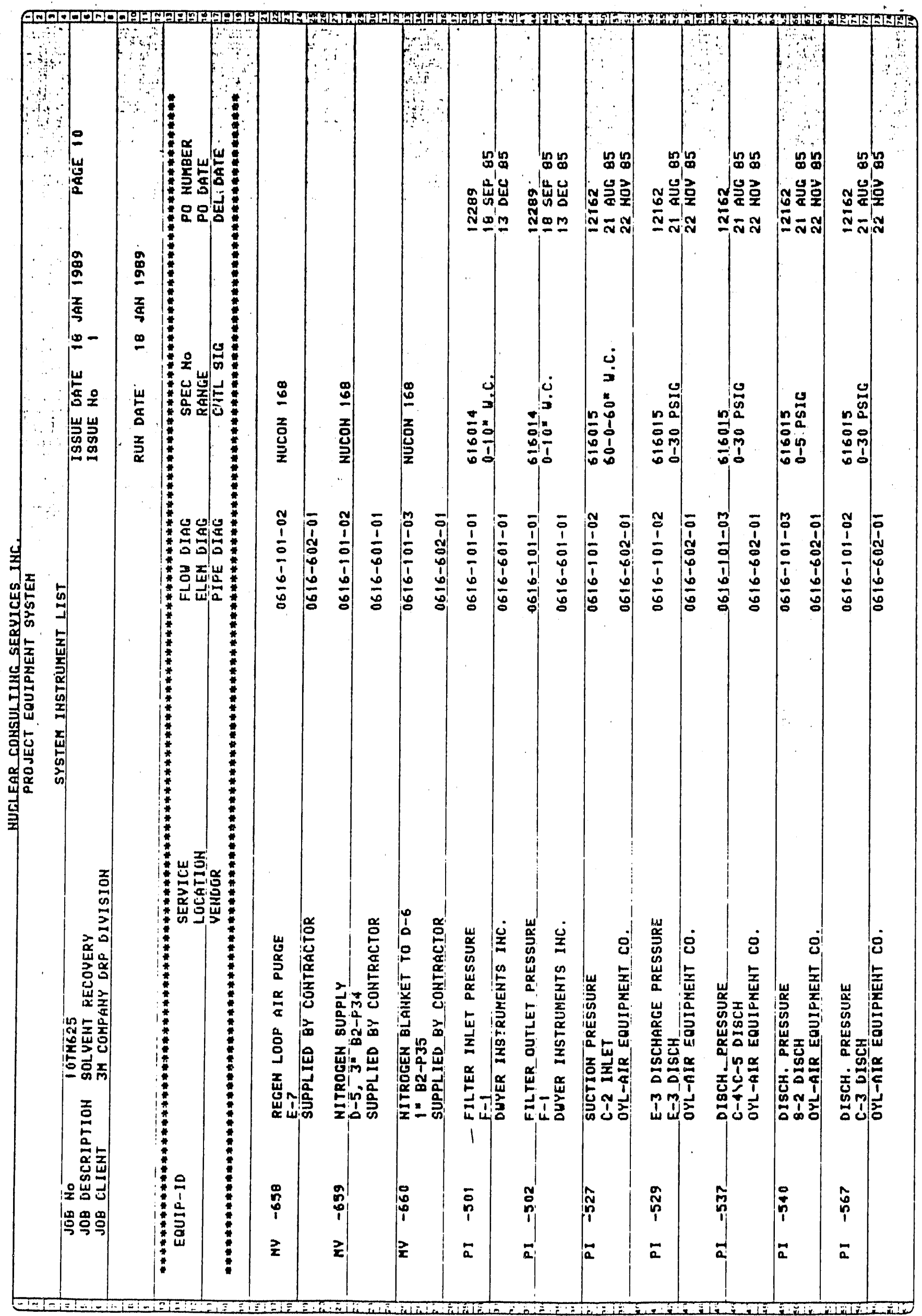




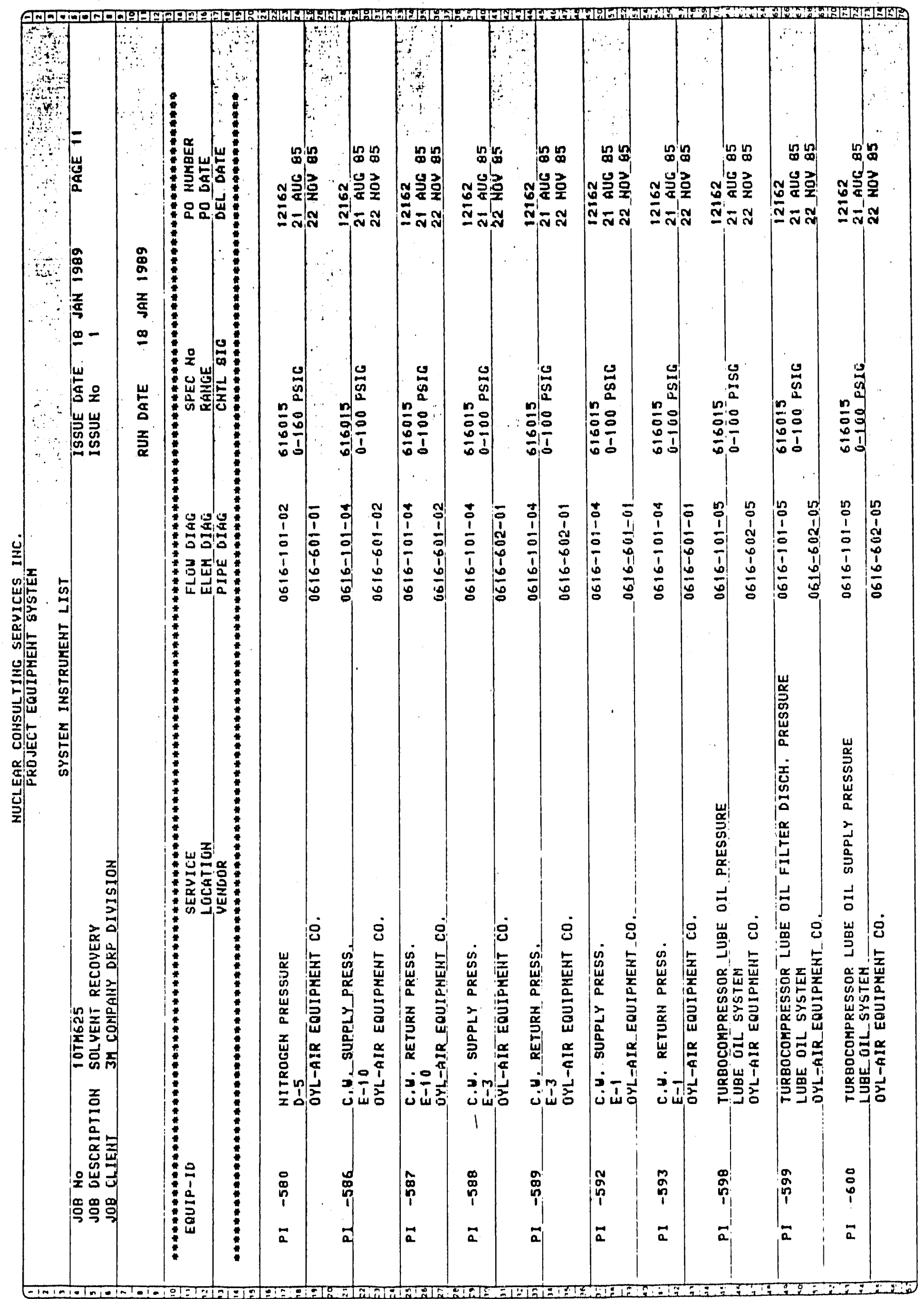




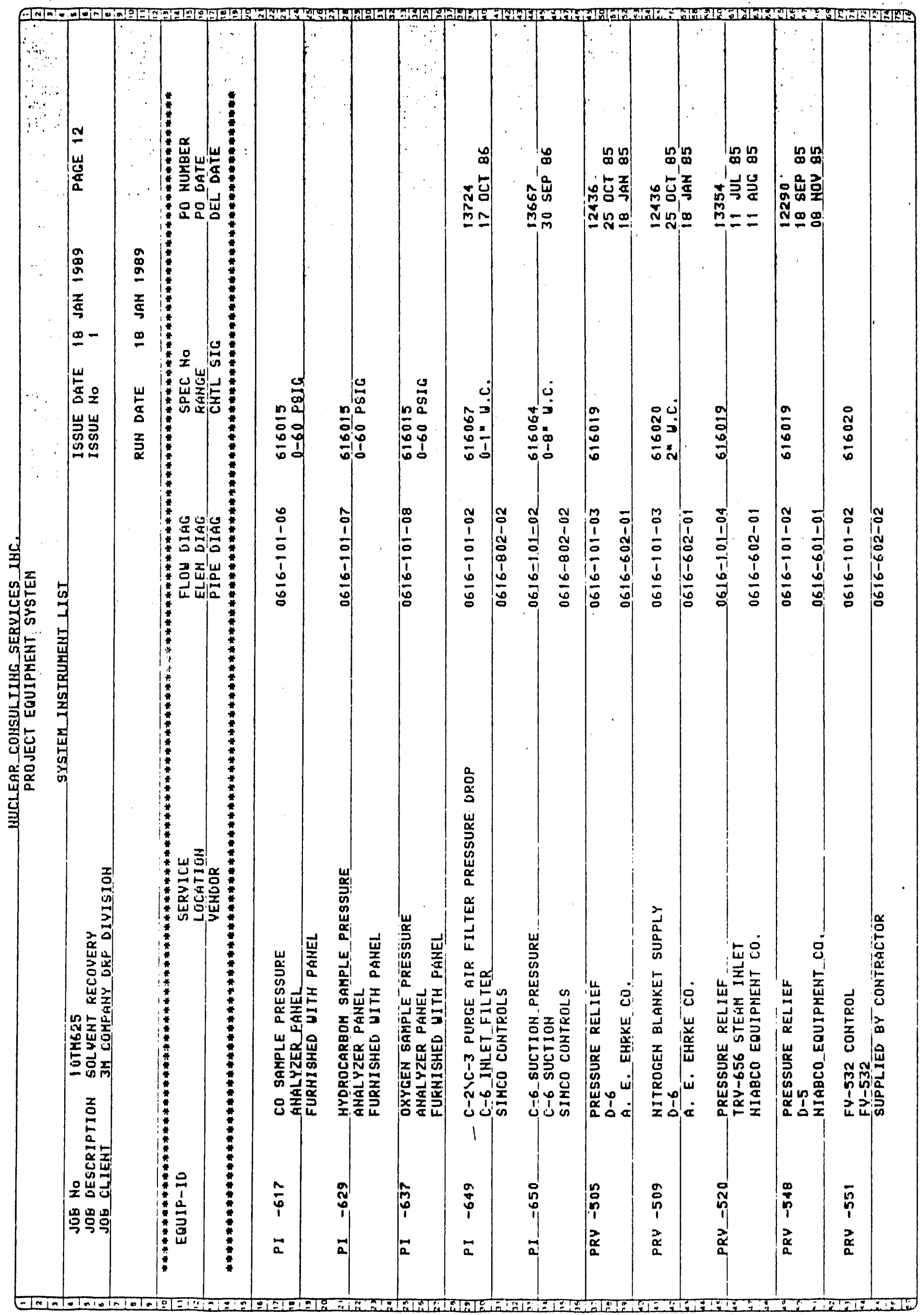




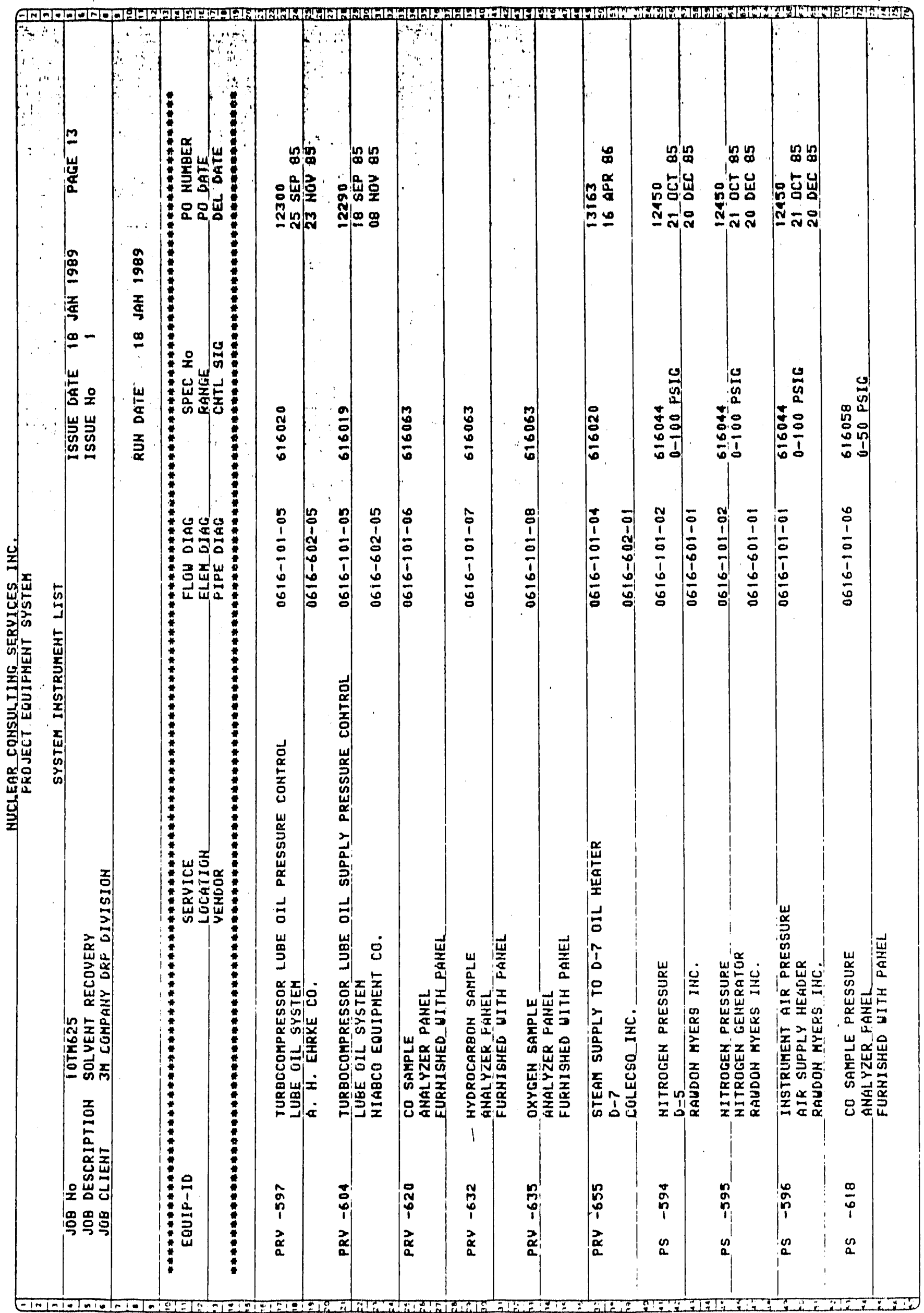




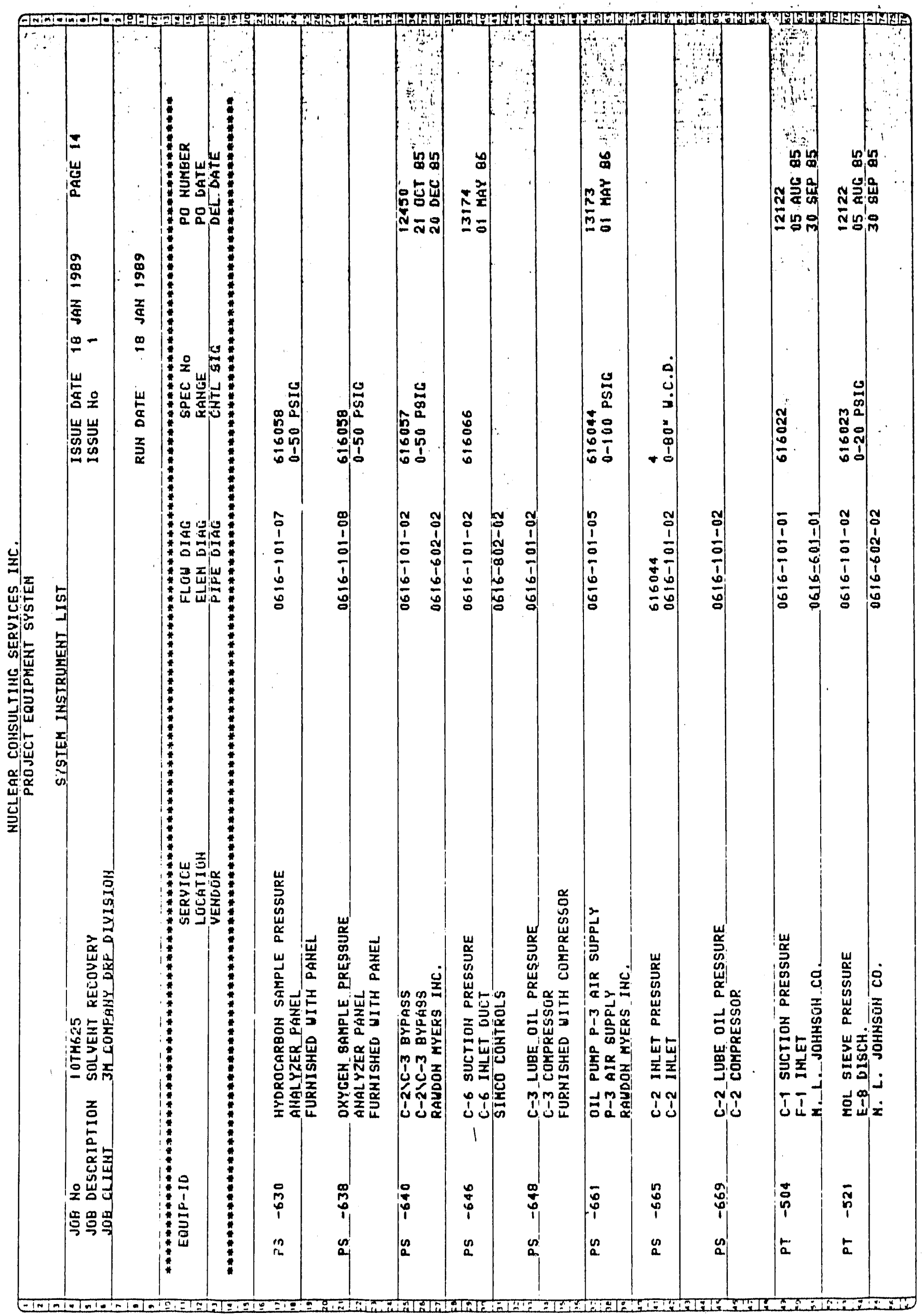




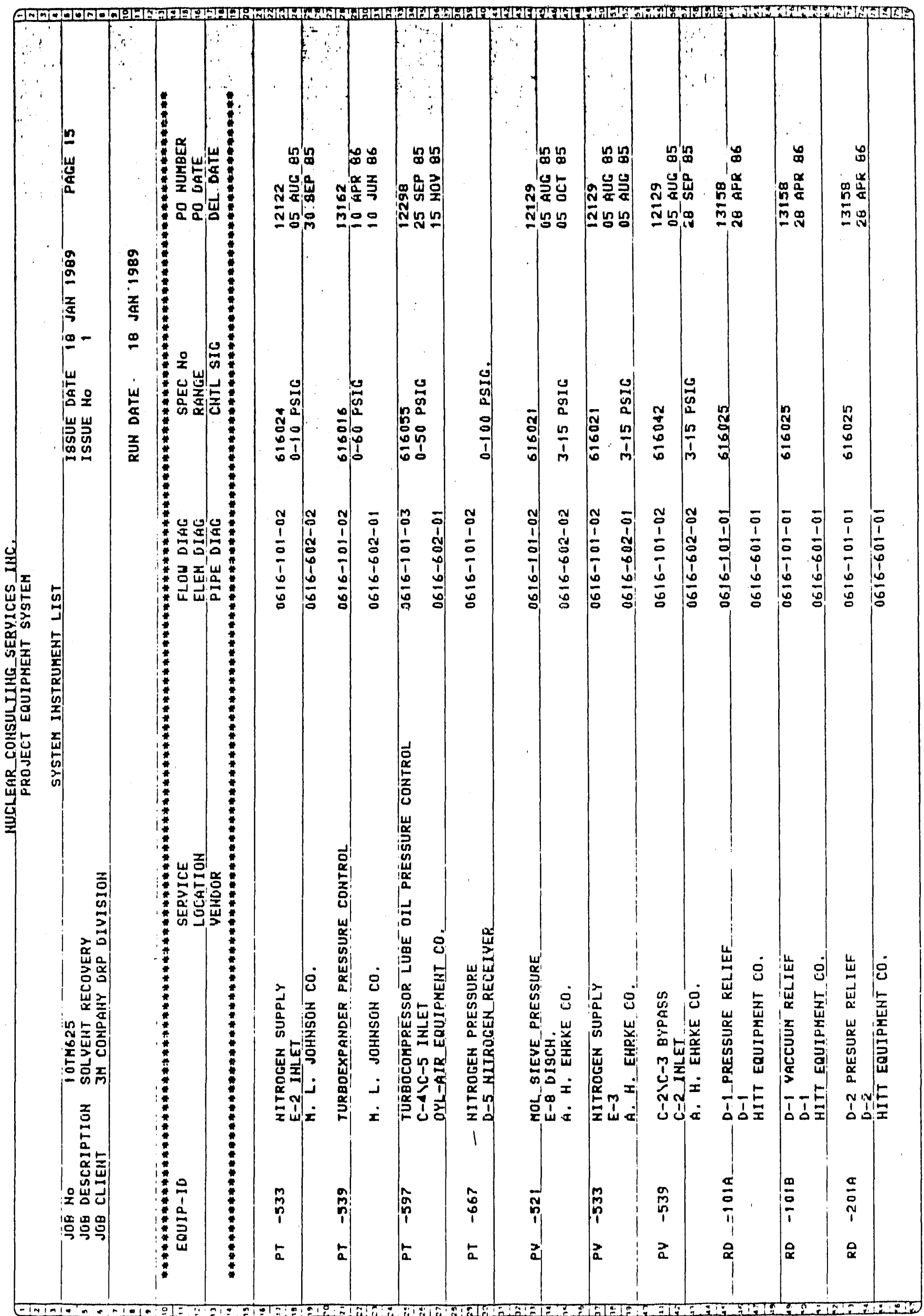




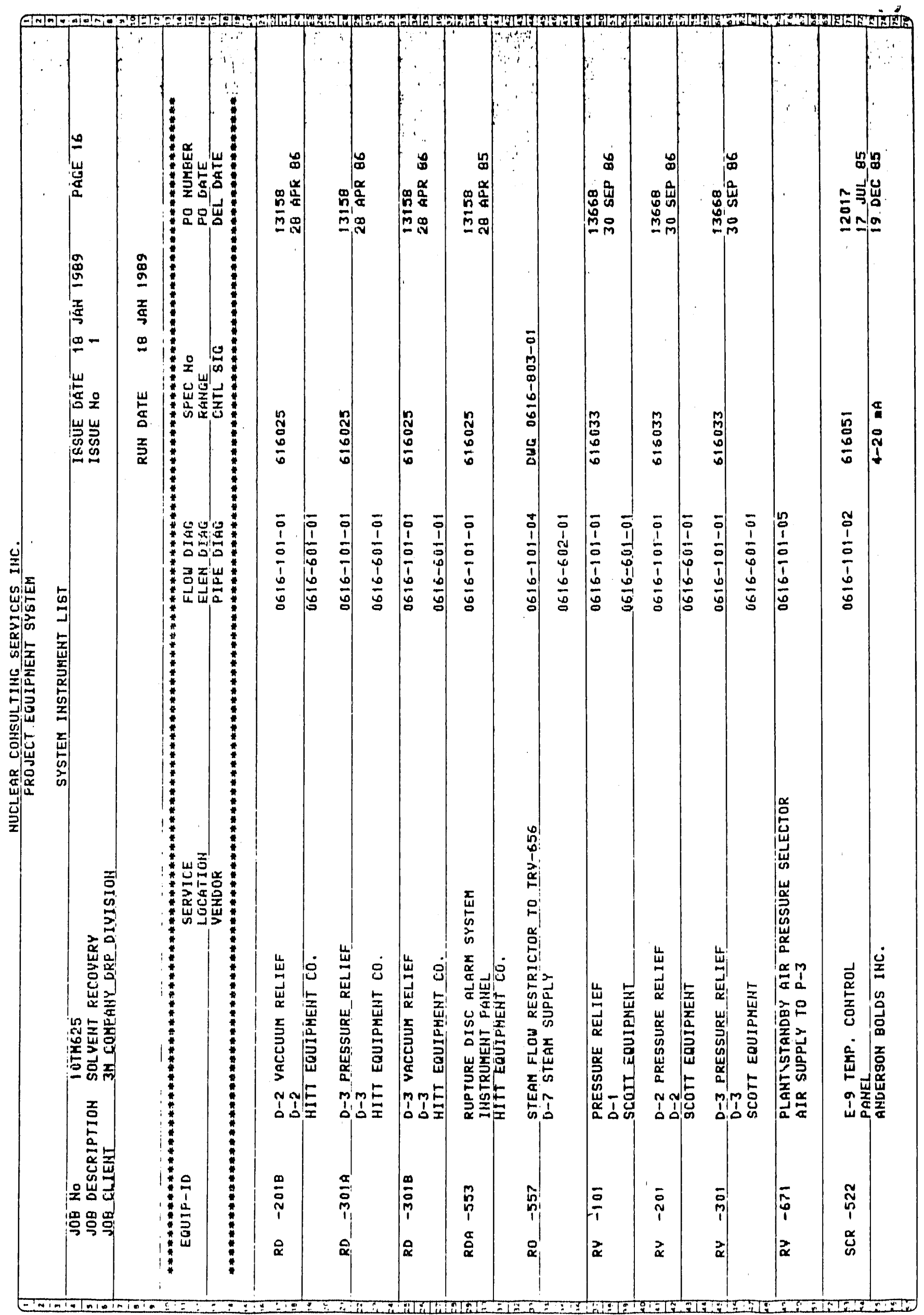




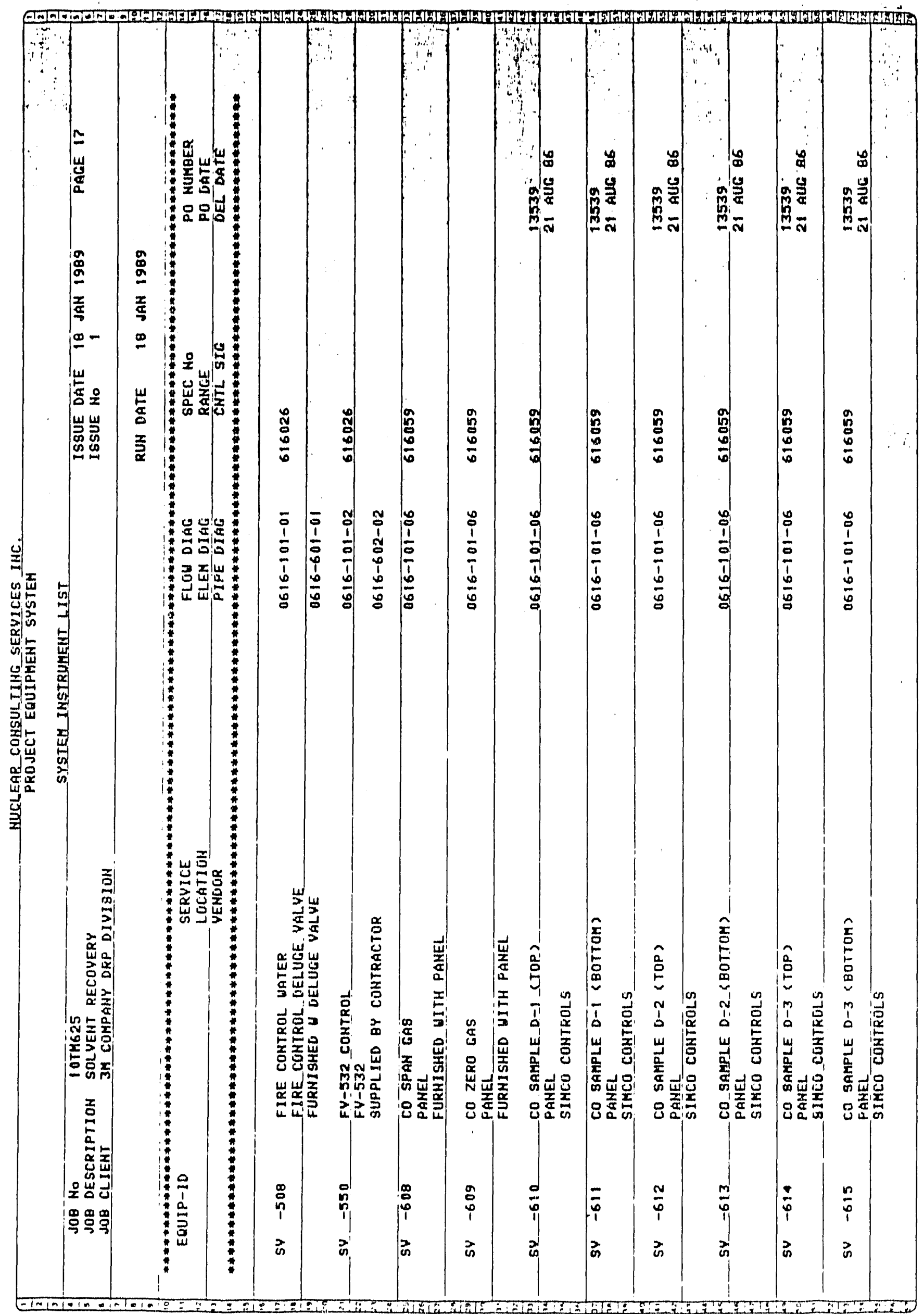




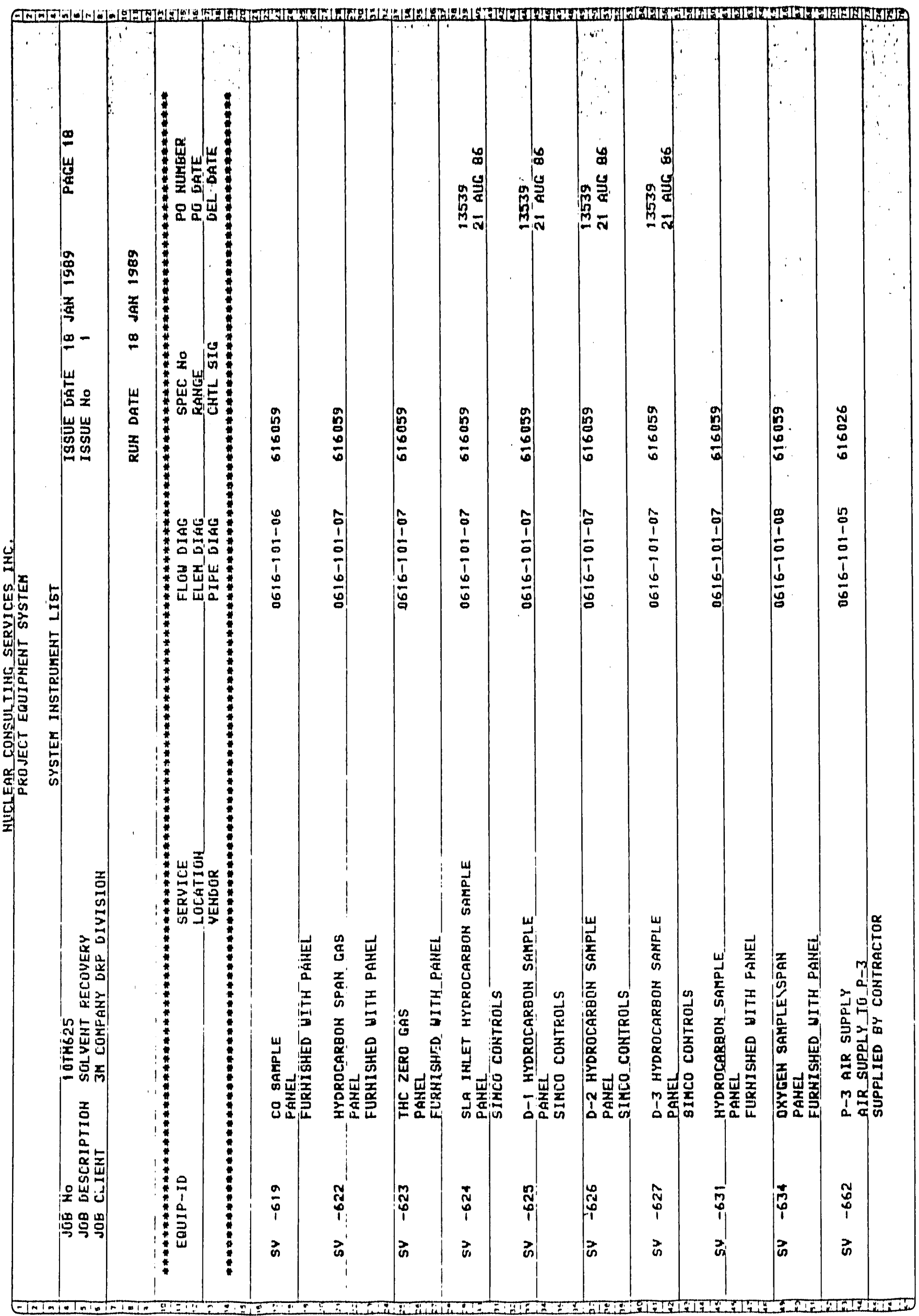




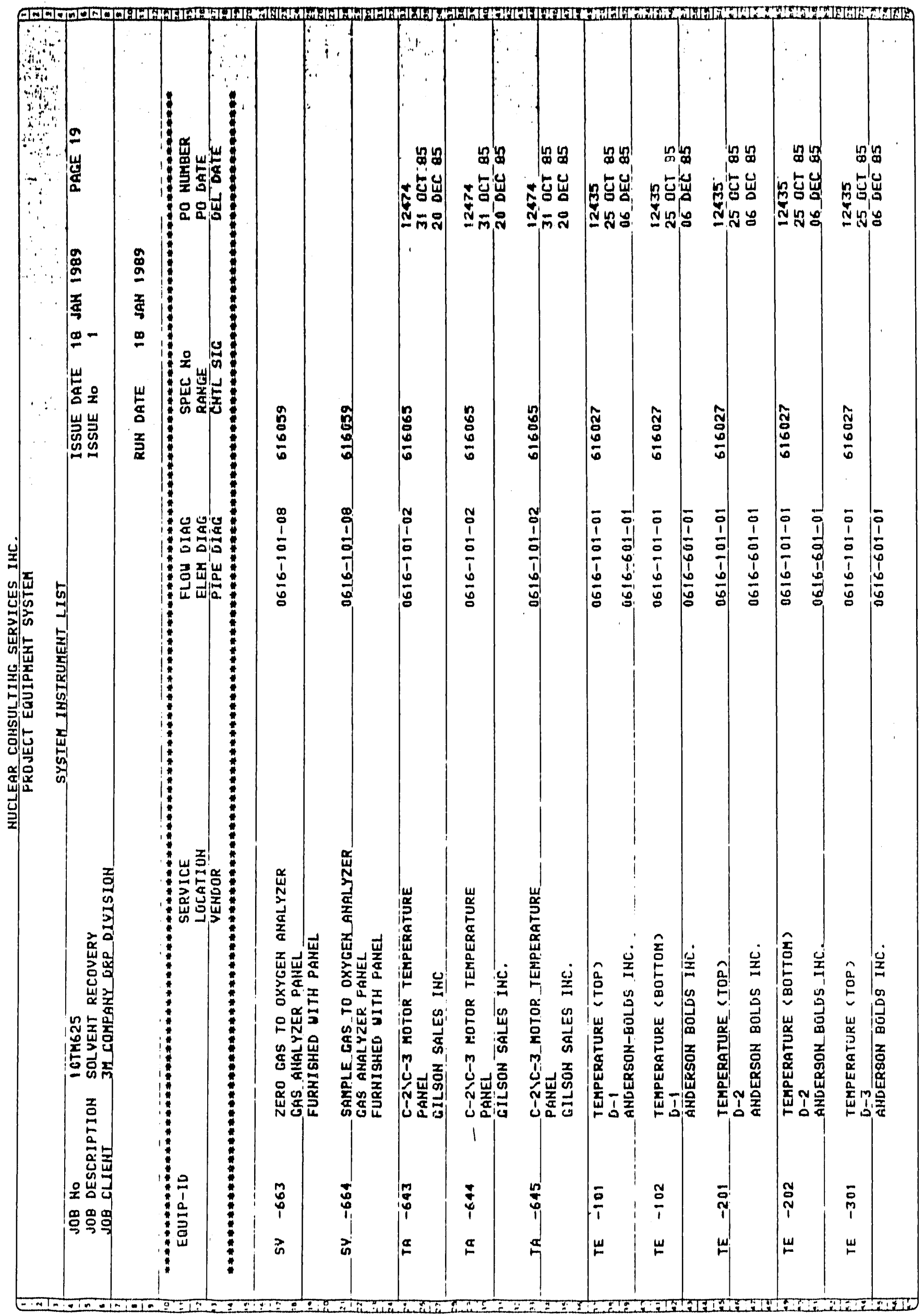




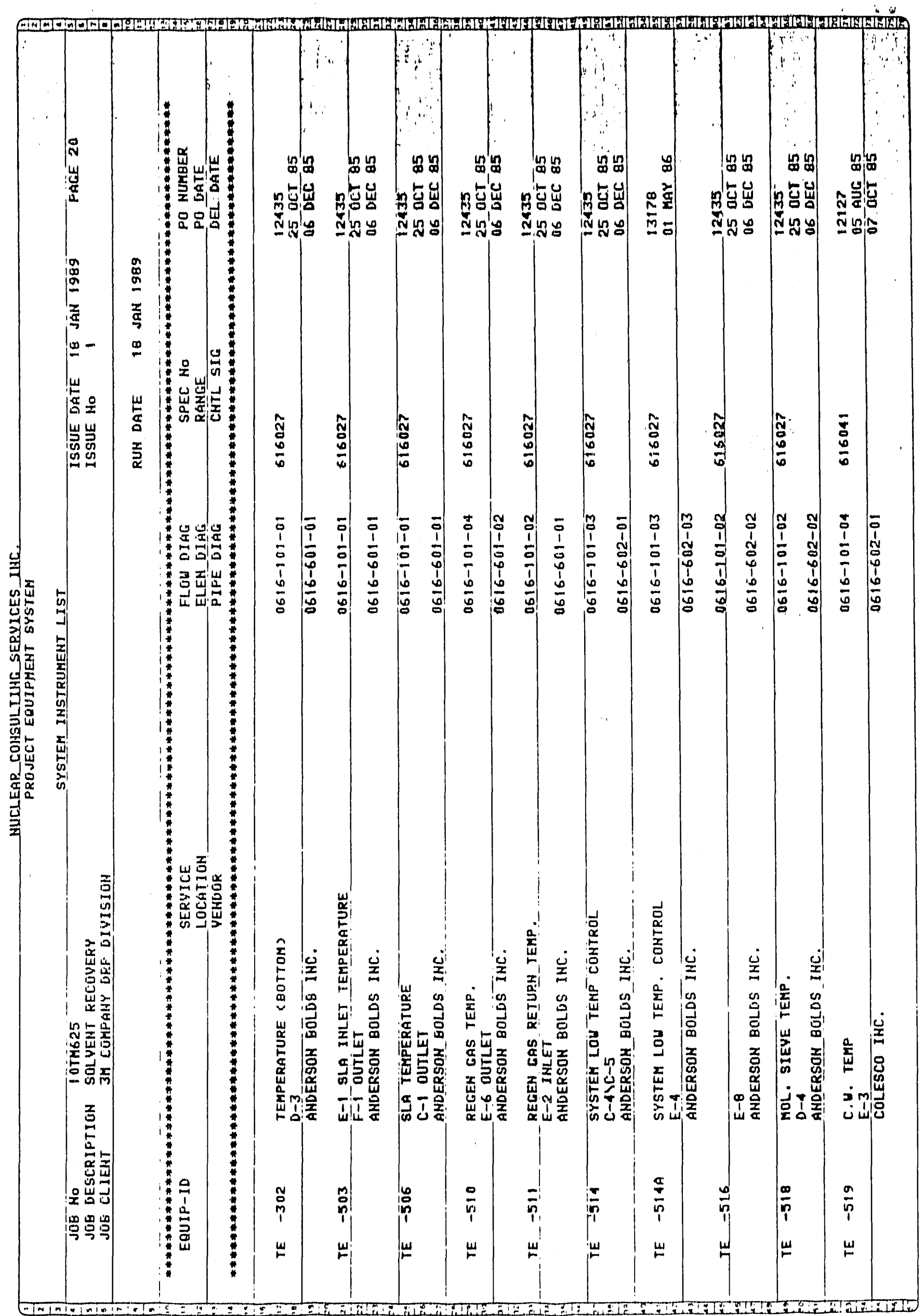




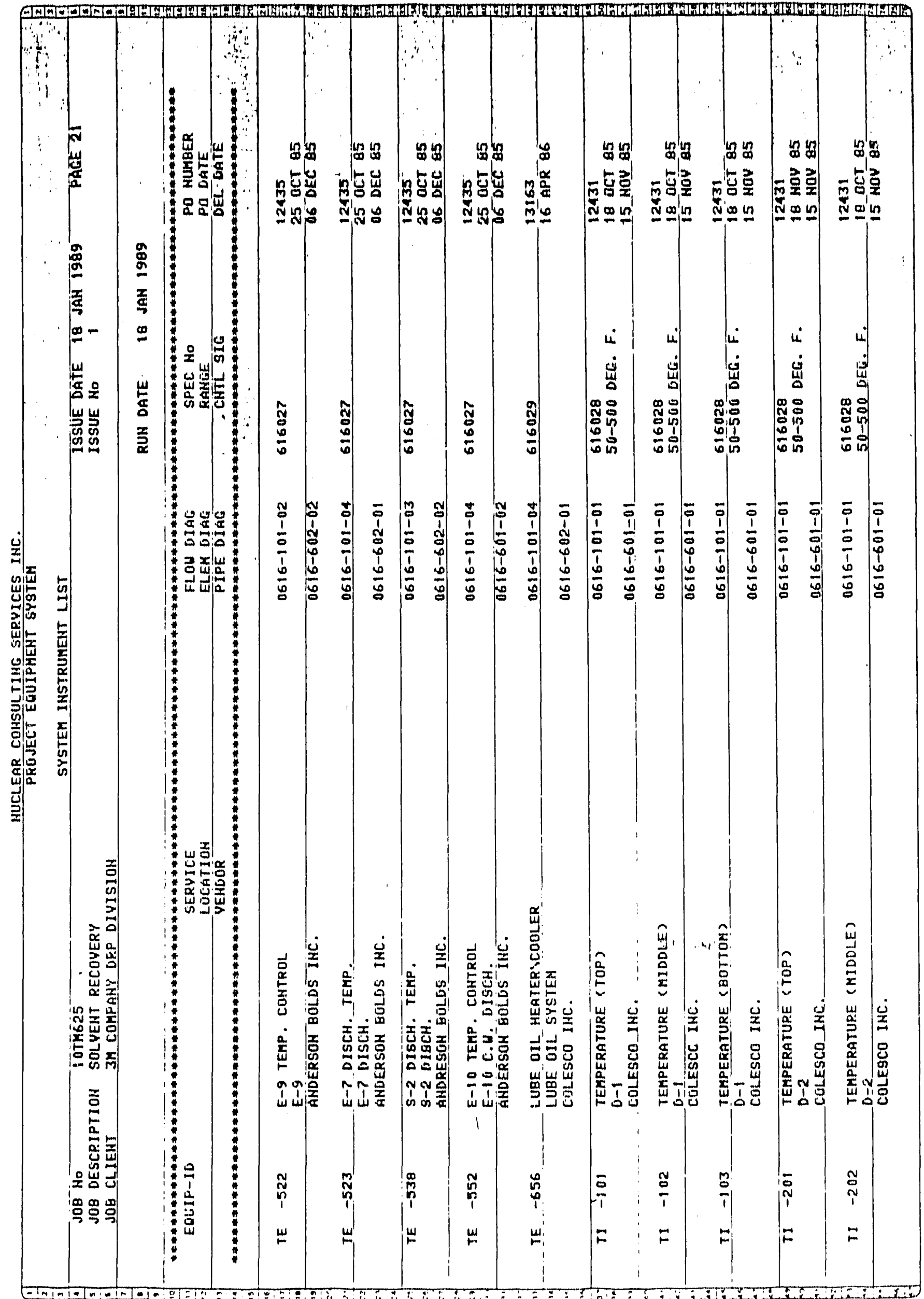




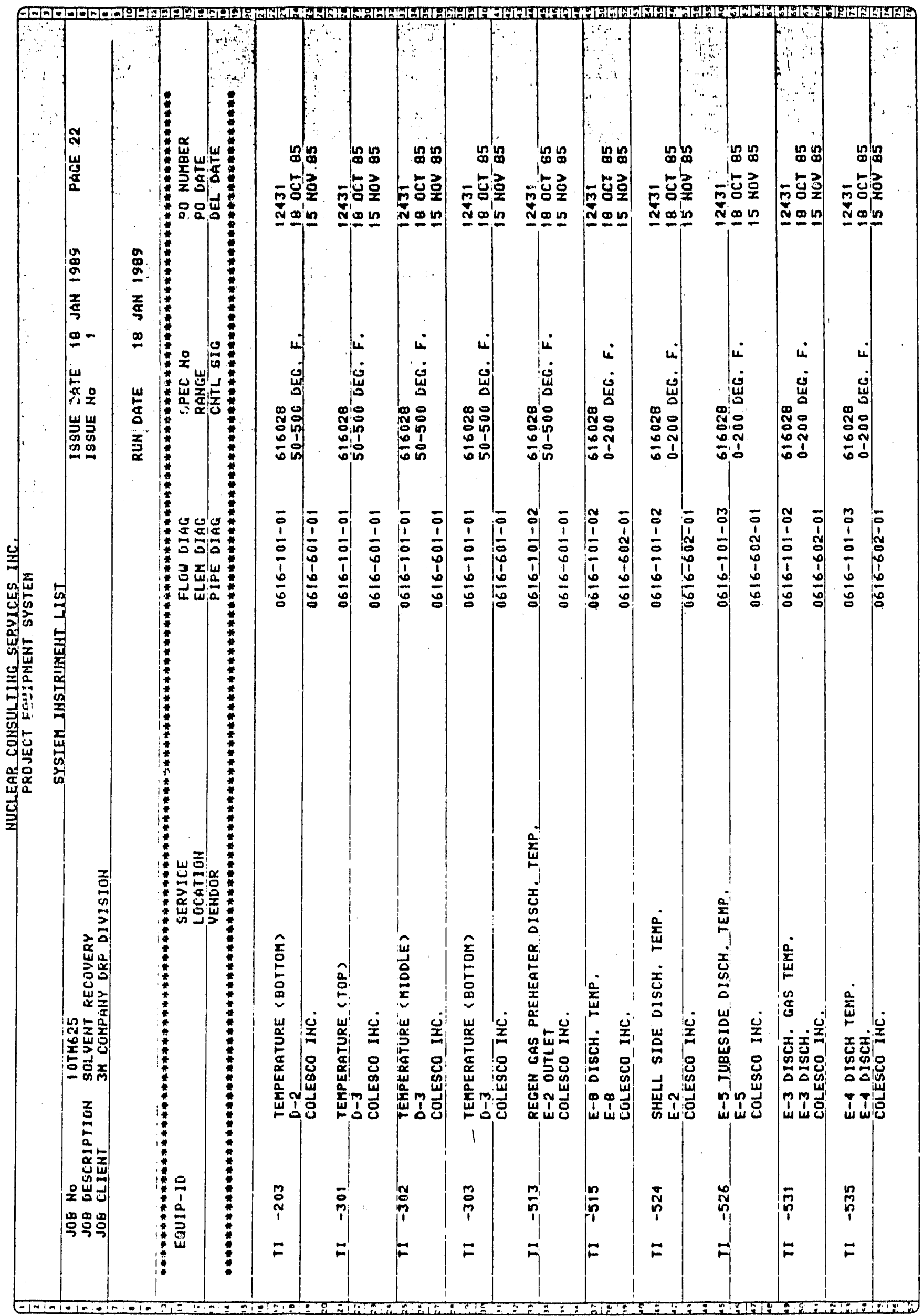




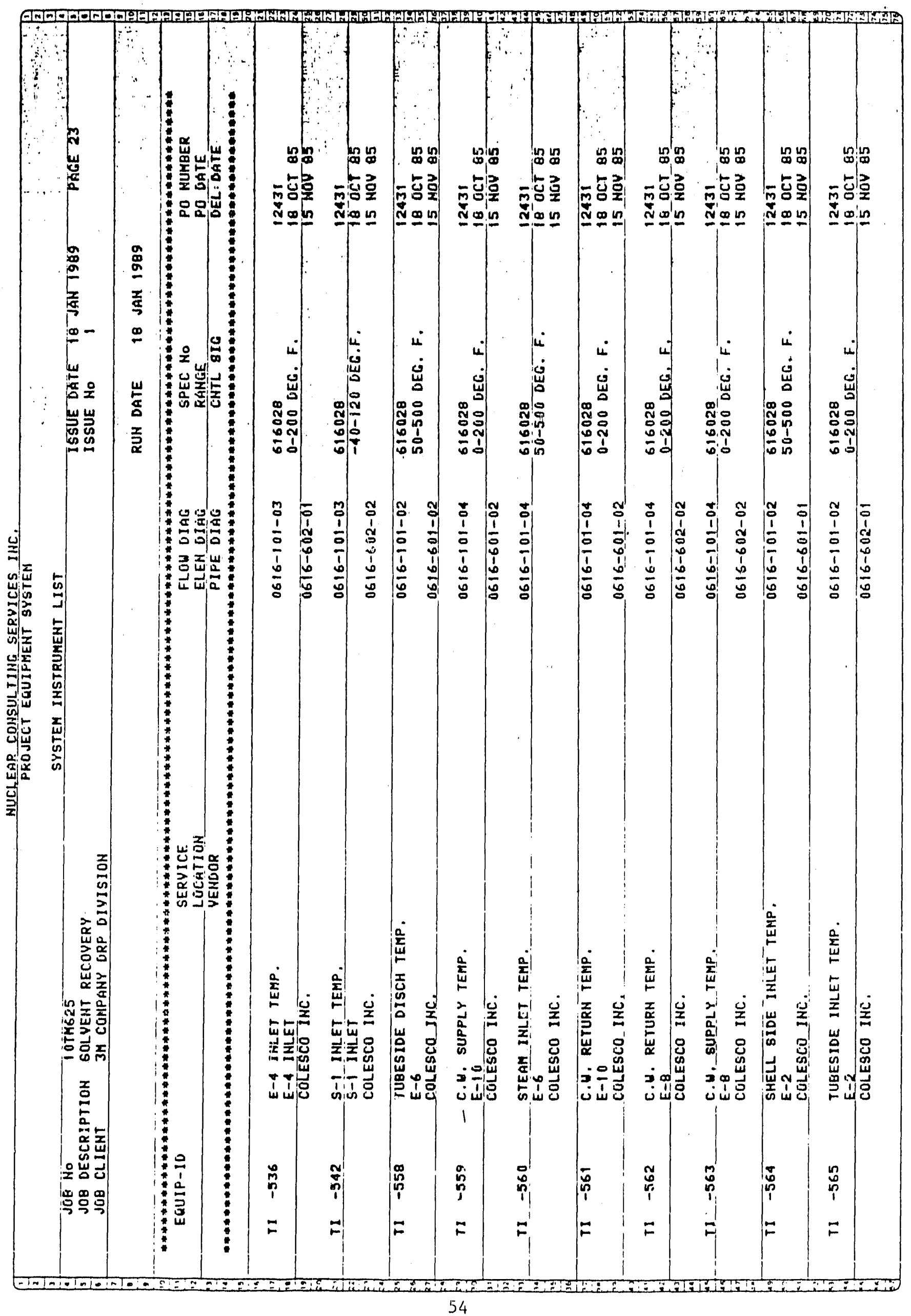




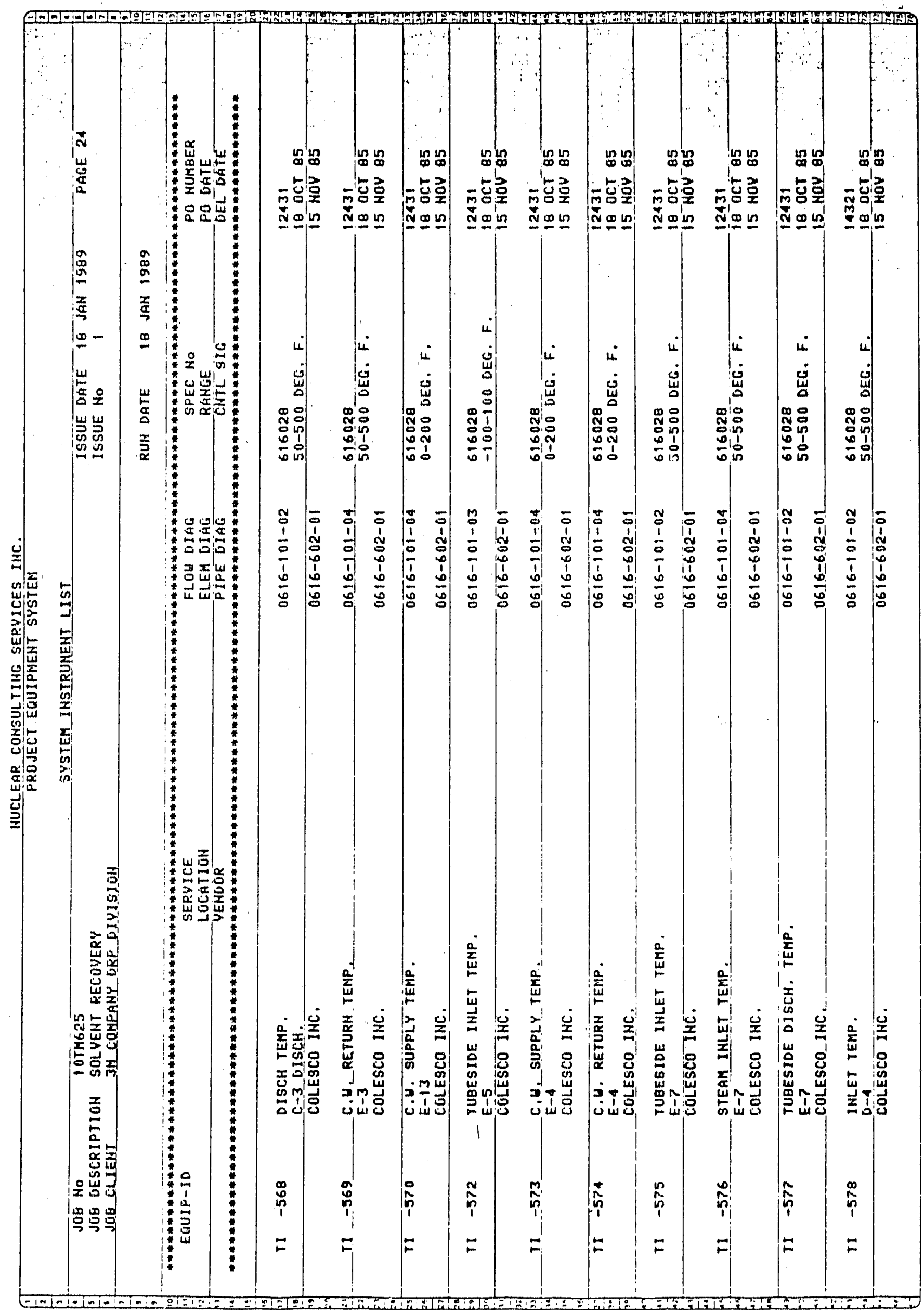




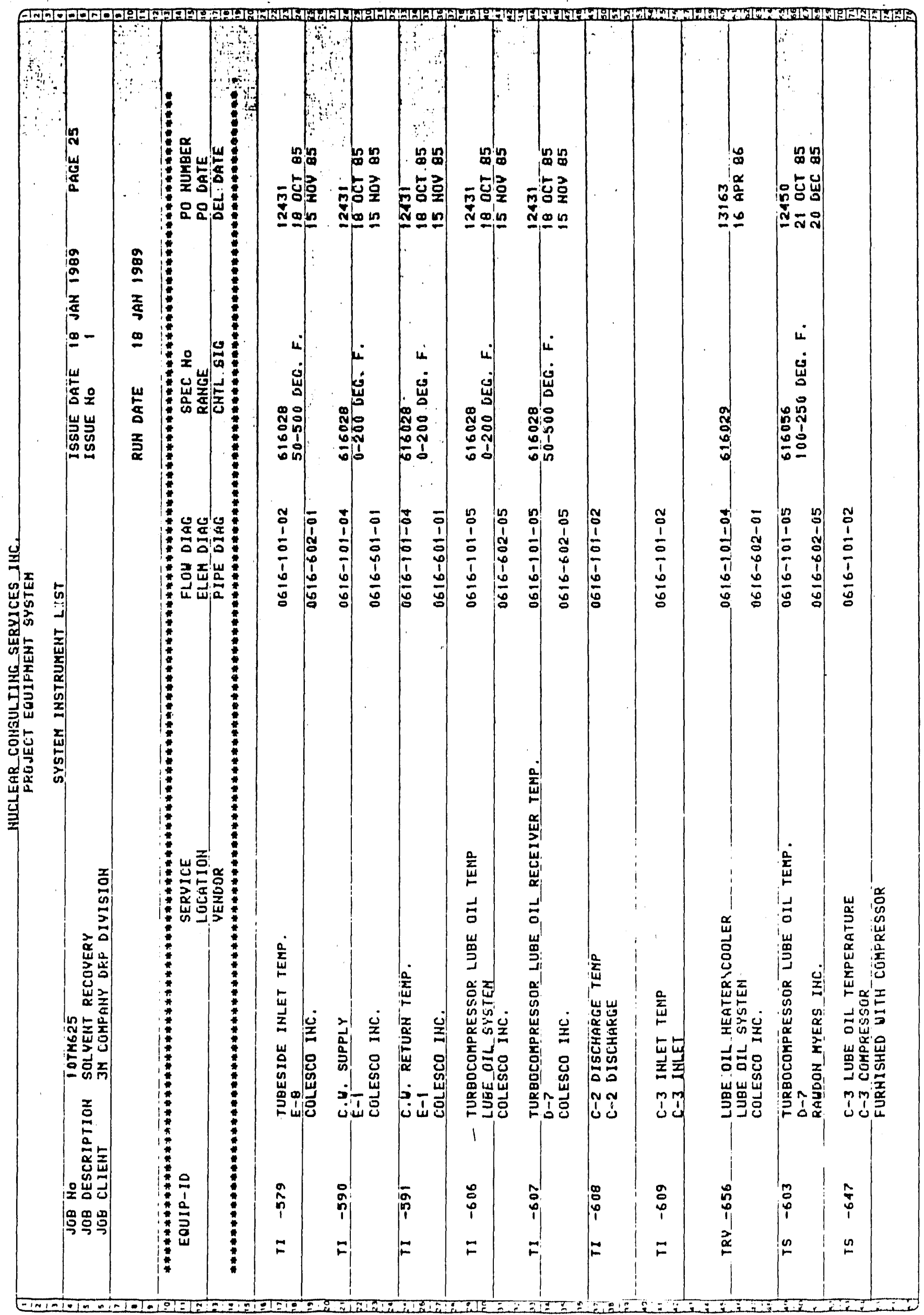




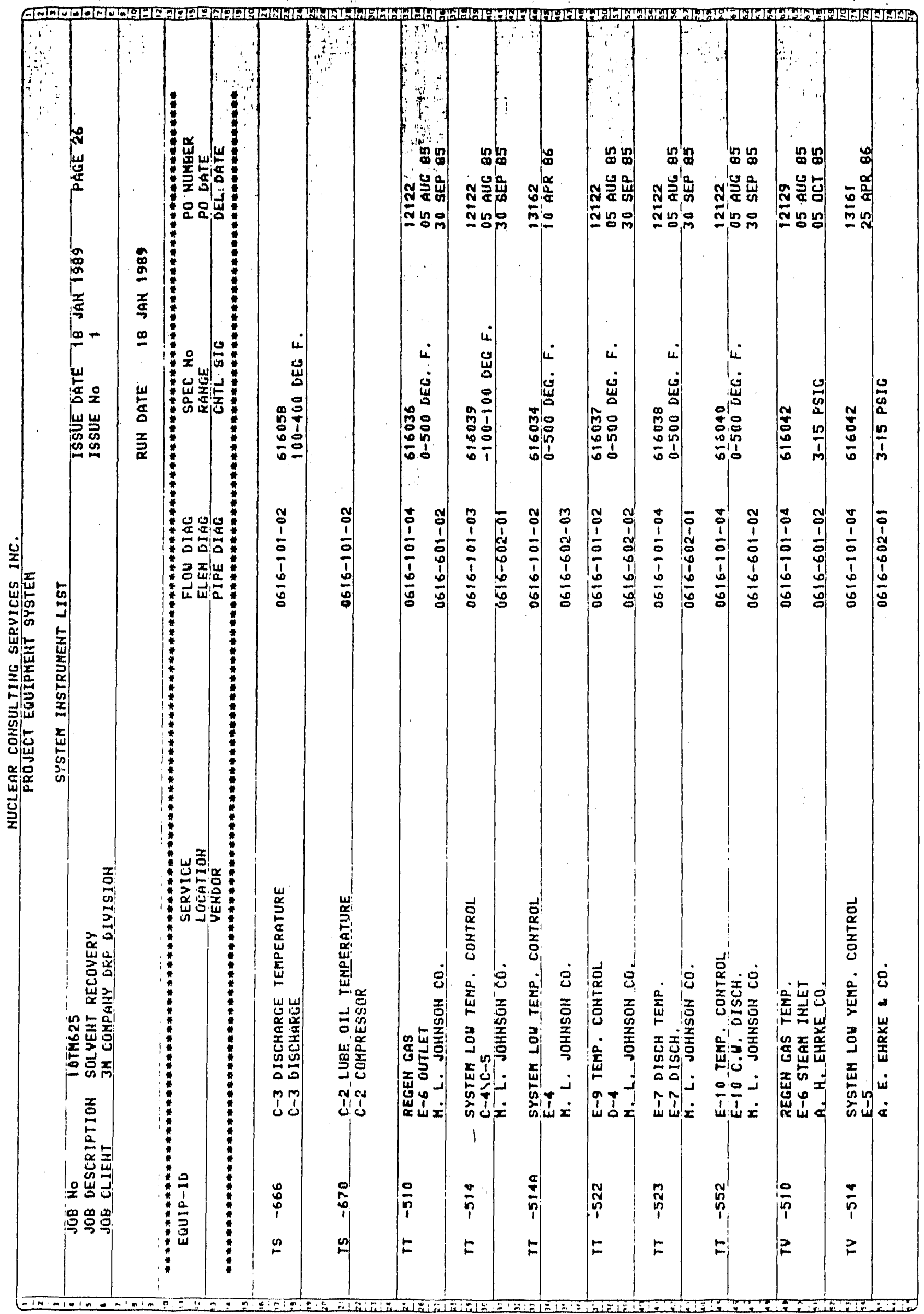




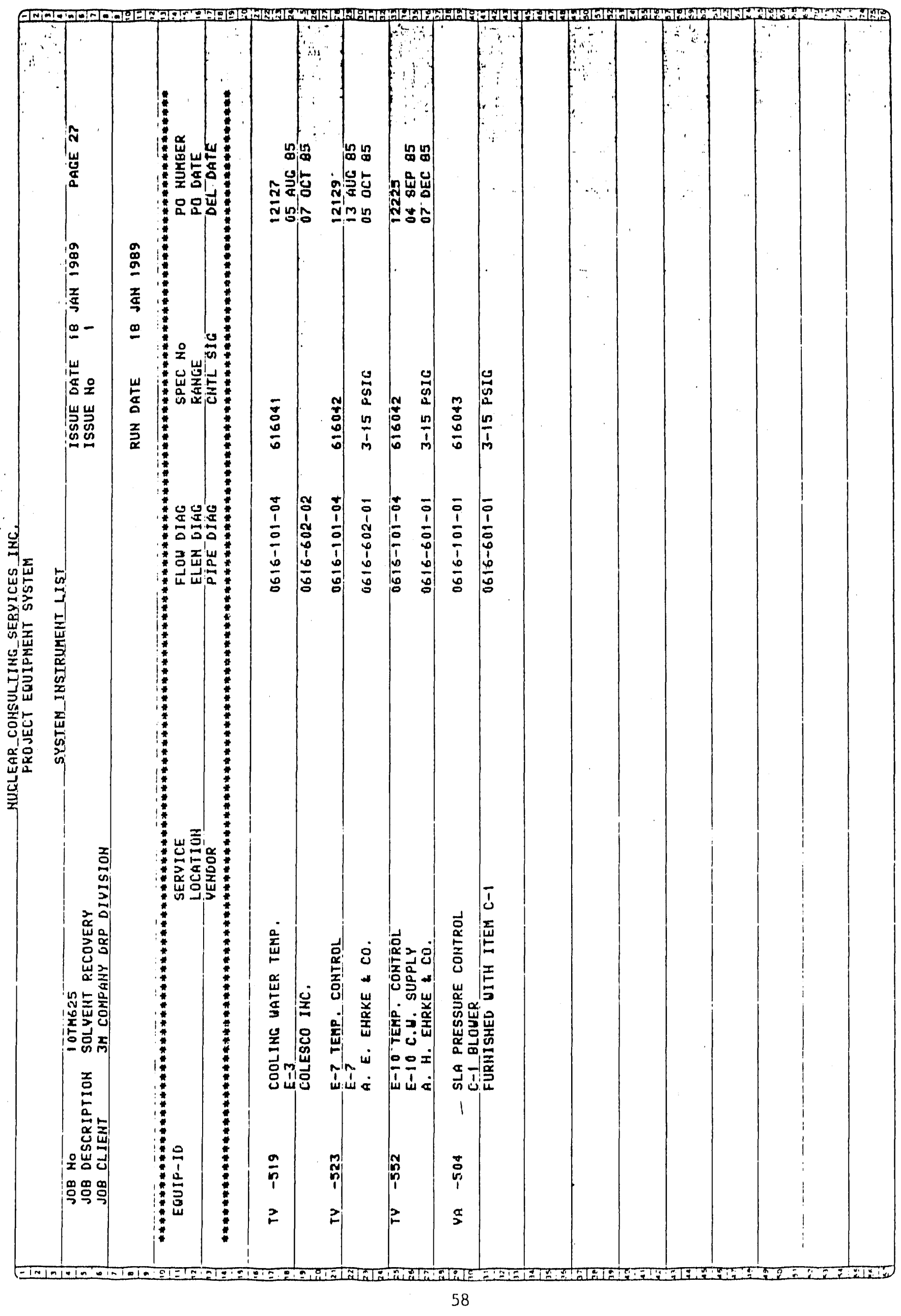




\section{APPENDIX B}

Mobile Brayton cycle heat pump system:

Mobile solvent recovery system is based on BCHP solvent recovery process using a free spindle turbo compressor. This system was designed, fabricated, and tested by Nucon under funding provided by the DOE, EPRI, 3M, Nucon, and SCE.

This appendix contains four P\&ID drawings, two piping equipment diagrams, and a detailed component description. 


\section{Nuclear Consulting Services, Inc.}

SYSTEM DESIGN DESCRIPTION

For

SMALL MOBILE VOC RECOVERY UNIT WITH BCHP

For

U.S. Department of Energy

office of Industrial Programs Project

Transportable Small scale VOC Recovery System

Distribution:

SCE: Roger Sung

EPRI: Ammi Amarnath

3M: Nirmal Jain

Robert Nelson

NUCON: Master File - IODE771

J. I. Kovach

R. S. Kingsley

J. C. Enneking

M. N. Magnus

J. M. Stephens

W. P. Freeman

NUCON 10DE771/03 Rev. 2 
NUCON 1ODE771/03

PREPARED BY

REVIEWED BY

QA APPROVAL

Original

Issue

23 Aug., 89 Mn Mngruus M.N. Magnus

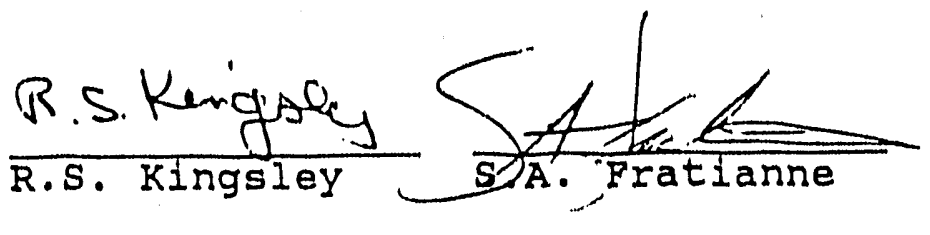

Revision 1

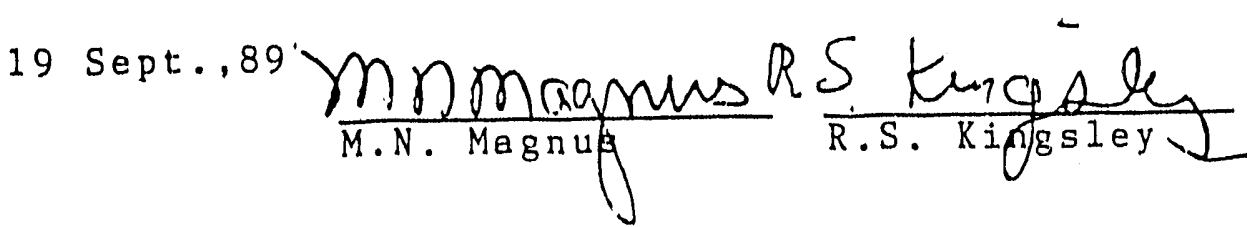

PREPARED BY

REVIEWED BY

Revision 2

20 Dec., 89

$\frac{\text { DD Dragnus }}{\text { M.N. Magnus }}$

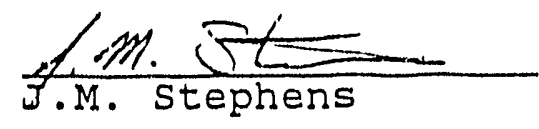

APPROVAI - QA

APPROVAI - MGMT.

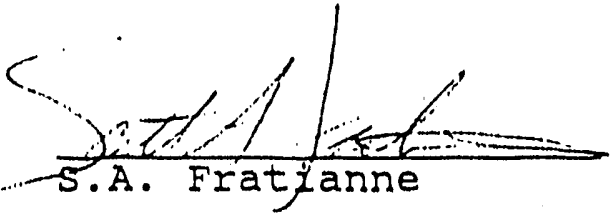

$\frac{\text { Peclawet S.tangalcy }}{\text { R.S. Kingsiey }}$ 
NUCON 10DE771/03 Rev. 2

SYSTEM DESIGN DESCRIPTION

For

SMALI MOBILE VOC RECOVERY UNIT WITH BCHP

Page

1.0 Summary

1

2.0 Functions

1

3.0 Performance Requirements

4

4.0 Modes of operation is

5.0 Codes, Standards, Regulatory Requirements 15

6.0 Design Conditions 16

7.0 Ervironmental conditions 17

8.0 Interface Requirements 18

9.0 Material Requirements 18

10.0 Mechanical Requirements 19

11.0 Structural Requirements 19

12.0 Electrical Requirements 19

13.0 Failure Effects Requirements 20

14.0 Accessibility, Maintenance, Repair and In-Service 20 Inspection Requirements

15.0 Personnel Requirements 20

16.0 Transportability Requirements 20

17.0 Fire Protection Requirements 20 
NUCON IODE771/03 ReV. 2

1.0 SUMMARY

1.1 General

A transportable solvent recovery unit using the Brayton Cycle Heat Pump (BCHP) technology is to be constructed for plant site solvent recovery testing in the southern California Edison sector of the state. The existing 250 CFM VOC recovery pilot plant built for $3 \mathrm{M}$ Co. Is to be converted from 2-stage conventional refrigeration to BCHP cryogenic refrigeration for solvent recovery.

1.2 The $250 \mathrm{CFM}$ VOC solvent recovery pilot plant built by NUCON (and now owned by NUCON) is to be returned to Columbus for refitting.

1.3 The system will be designed for continuous operation of adsorption of solvents from an air stream. The regeneration of the off-line carbon bed is performed automaticaliy in a semi-continuous operation.

1.4 The adsorption media will be two types:

1) Voc-type activated carbon selected for this process on the basis of laboratory studies,

2) A noncarbonaceous, highly active adsorbent with hydrophobic properties meeting the requirements for gas phase operation.

1.5. The pilot plant will be mounted on a commercial trailer with standard fittings for attachment to a tractor for hauling.

1.6 The fittings for connection to client piping and ductwork will meet industrial standards for the service.

1.7 Instrumentation will be provided for both on-site readout (by computer) and off-site readout (at NUCON) .

\subsection{FUNCTIONS}

The Small Mobile VOC Recovery Unit with BCHP will have the following principal components which have the identified functions: 
NUCON 1ODE771/03 ReV. 2

2.1 Carbon Adsorber Vessels (D-1, D-2)

A dual bed carbon adsorption system w111 provide continuous operation capability for damonstration purposes. This is achleved by adsorbing on one bed while the second bed is isolated from the adsorption process and is regenerated with hot nitrogen. The beds are switched from the adsorb mode to regeneration mode by the pre-programed PLC (Programmable Logic controlier).

2.2 SIA COOLer $(E-I)$

Cools the incoming solvent Iaden Air (SIA) stream to ambient temperature.

2.3 Blower $(\mathrm{C}-1)$

A forced draft fan to drive the solvent Laden Air (SLA) through the carbon bed and out the exhaust staok.

2.4 Roughing Compressor $(\mathrm{C}-2)$

Provides the motive force for the closed loop nitrogen circulation for regeneration of the carbon beds.

2.5 Mol. Sieve Bed (D-3)

Provides for removal of moisture from the solvent-water vapor regen gas stream prior to the low temperature refrigeration step.

2.6 Turbo Compressor/Expander $(\mathrm{C}-3)$

Provides for cryogenic cooling of the regen gas stream which results in direct condensation of the solvents stripped from the carbon bed.

2.7 Refrigeration Condenser $(E-5)$

A gas-to-gas heat exchanger for subcooling and partial condensing of solvents in the regen gas stream. This heat exchange is an energy saving (i.e., recuperation) process. 
NUCON 1ODE771/03 REV. 2

2.8 Regen Cas Preheater (E-2)

A gas-to-gas heat exchanger that provides heat (energy) recovery during regeneration of the carbon bed.

2.9 Turbo Compressor After Cooler (E-4)

Removes the heat of compression developed by the turbo compressor $(\mathrm{C}-3)$ by water cooling. It also serves as a means of temperature control of the turbo expander outlet gas.

2.10 Separators $(S-1, S-2)$

Provide phase separation between condensed (11quid) solvent and the regen gas stream.

2.11 Regen Gas Heater $(E-6)$

Raises the temperature of the regen gas to the desired operating level for solvent stripping.

2.12 Mol Sieve Heater $(E-8)$

Heats the regen gas to the operating temperature required for mol sieve regeneration (moisture stripping).

2.13 Compressor After Cooler $(E-3)$

Removes the heat of compression developed by the Roughing Compressor $(\mathrm{C}-2)$.

2.14 Gas Cooler $(E-7)$

Provides cooling of the regen gas (to ambient temperature) during the carbon bed cool-down cycle.

2.15 Gas Cooler $(E-9)$

Provides cooling of the mol sieve regen gas (to ambient temperature) during the mol sieve moisture stripping operation. 
NUCON 10DE771/03 ReV. 2

2.16 Gas stream Analyzers (GA-509, GA-51.9, GA-521)

2.16.1 GA-509 Measures the solvent concentrations in the adsorption bed Inlet SIA (Solvent Laden AIr) stream and the adsorption bed exhaust air stream.

2.16 .2 GA-519 Measuxes the dew point temperatures of the regen gas stream.

2.16 .3 GA-521 Measures the oxygen concentration of the regen gas stream.

2.17 Instruments and controls

The Small Mobile voc Recovery Unit with BCHP will contain sufficient instrumentation and control to:

- safely operate the system

- monitor and control all process dependent variables

- store process independent and dependent variables

- transmit process values to Calumbus

- monitor and store all process variables required to specify and design a full scale voc recovery system with a BCHP.

- meter process utility consumption (i.e., power and cooling water)

3.0 PERFORMANCE REQUIREMENTS OF MAJOR EQUIPMENT

3.1 Adsorber Vessels $(D-1, D-2)$

Twenty four (24") inch diameter vessels designed for airflow of 250 CFM at a velocity of 76 FPM. The height of the bed is 30 inches.

\subsection{Adsorber Beds}

Each adsorber will have a 30 inch deep bed $(7.9$ cubic feet). Adsorbant described as follows: 
NUCON IODE771/03 Rev. 2

1) One bed to be a selected grade of activated carbon.

2) The second bed will be a hydrophobic noncarbonaceous adsorbent (should it become available). Otherwise, both beds will have the same carbon.

3.3 SLA COOler $(E-I)$

A finned-tube water cooled exchanger capable of cooling the incoming gas stream from $300^{\circ} \mathrm{F}$ to $90^{\circ} \mathrm{F}$ using $80^{\circ} \mathrm{F}$ cooling water.

3.4 SIA Blower $(\mathrm{C}-1)$

The blower is rated for airflow at $250 \mathrm{CFM}, 90^{\circ} \mathrm{F}, 21$ inch static pressure. The drive is a $3 \mathrm{HP}, 3,500$ RPM, $460 \mathrm{~V}, 3 \mathrm{PH}, 60 \mathrm{~Hz}$ motor.

3.5 Roughing Compressor (C-2)

The compressor is a positive displacement type rated at 150 SCFM, 24.6 psi pressure rise, equipped with inlet and outlet silencers for sound attenuation, and speed control using sheaves. The drive is a $20 \mathrm{HP}, 1800 \mathrm{RPM}$, $460 \mathrm{~V}, 3 \mathrm{PH}, 60 \mathrm{~Hz}$ motor. The motor enclusure is TEFC.

3.6 Mol Sieve Vessel $(D-3)$ and Mol Sieve Bed

The mol sieve vessel is 24 inches diameter by 48 inches high. The mol sieve bed is 24 inches diameter by 24 inches deep and contains 280 pounds of Type $3 \mathrm{~A}$ molecular sieve. The mol sieve is capable of adsorbing 28 pounds of water. The dew point of the regen gas will be reduced to $-20^{\circ} \mathrm{F}$ or lower.

3.7 Turbo Compressor/Expander (C-3)

The turbo compressor/expander will provide cryogenic refrigeration. The regen gas flow consists of 639 $\mathrm{lb} / \mathrm{hr}$. of nitrogen and $29 \mathrm{Ib} / \mathrm{hr}$. (average) of solvent. The expander outlet gas temperature will be at $-80^{\circ} \mathrm{F}$ or lower. Approximately one-half of the solvent ill condense in the interstage refrigeration condenser (E-5) and the balance condenses in the expander outlet (Note: condensation is not complete and will be limited by the partial pressure of the solvent at the condensing temperature). 
NUCON 10DE771/03 Rev. 2

$|2|$

$+-+$

3.8 Refrigeration Condenser (E-5)

In this gas-to-gas exchanger, the turbo compressor discharge gas will be cooled to zero $\left(0^{\circ}\right)$ degrees $F$ and the expander discharge gas temperature rises from $-80^{\circ} \mathrm{F}$ to about $40^{\circ} \mathrm{F}$. More than one-half of the solvent will condense under these conditions.

3.9 Regen Gas Preheater (E-2)

This gas-to-gas exchanger recovers the heat from the solvent laden regen gas leaving the adsorber. The exhaust gas is cooled from $350^{\circ} \mathrm{F}$ (max.) to $100 \% \mathrm{~F}$. The stripping gas will be heated to about $300^{\circ} \mathrm{F}$ (max.).

3.10 Turbo Compressor After Cooler (E-4)

The regen gas temperature at the discharge of the compressor is expected to be $270^{\circ} \mathrm{F}$. The after cooler $(E-4)$ will cool the gas to $100^{\circ} \mathrm{F}$ using $80^{\circ} \mathrm{F}$ cooling water.

3.11 Separators $(S-1, S-2)$

The separator S-I provides phase separation between a $639 \mathrm{lb} / \mathrm{hr}$. $\mathrm{N}_{2}$ gas stream up to $30 \mathrm{lb} / \mathrm{hr}$. entrained liquid. The operating conditions are: pressure: 25 psig, temperature: $\mathrm{O}^{\circ} \mathrm{F}$.

Separator s-2 performs the same function as s-1. The gas flow is $639 \mathrm{lb} / \mathrm{hr}$. and entrained liquid capacity of $30 \mathrm{lb} / \mathrm{hr}$. The operating conditions are: pressure: 2 psig, temperature: $-80^{\circ} \mathrm{F}$.

3.12 Regen Gas Heater $(E-6)$

Provides up to $45,000 \mathrm{BTU} / \mathrm{hr}$. to heat the regen gas to the operating temperature of $360^{\circ} \mathrm{F}$. The heater is rated at $20 \mathrm{~kW}, 460 \mathrm{~V}, 3 \mathrm{PH}, 60 \mathrm{~Hz}$. The expected power usage will be 10 to $15 \mathrm{KW}$.

3.13 Mol Sieve Heater $(E-8)$

Heats the regen gas stream to $450^{\circ} \mathrm{F}$ for regeneration of the mol sieve. The required heating capacity is $17 \mathrm{KW}$. The heater will be sized for $25 \mathrm{~kW}$. 
NUCON 1ODE771/03 ReV. 2

3.14 Roughing Compressor After Cooler (E-3)

Coois the compressed regen gas stream from $279^{\circ} \mathrm{F}$ to $100^{\circ} \mathrm{F}$. The cooling water flow will be $4.0 \mathrm{gpm}$ at $15^{\circ} \mathrm{F}$ temperature rise.

3.15 Gas Cooler $(E-7)$

Cools the $150 \mathrm{SCFM}$ regen gas stream from $350^{\circ} \mathrm{F}$ (max.) to $100^{\circ} \mathrm{F}$ during the carbon bed cooldown. The cooling water flow will be $5.3 \mathrm{gpm}$ at $15^{\circ} \mathrm{F}$ temperature rise.

3.16 Gas Cooler $(E-9)$

Cools the $150 \mathrm{SCFM}$ mol sieve regen gas from $450^{\circ} \mathrm{F}$ to $100^{\circ} \mathrm{F}$. The cocling water flow will be $7.5 \mathrm{gpm}$.

3.17 Gas Stream Analyzers (GA-509, GA-519, GA-521)

3.17.1 GA-509 VOC Analyzer

Beckman Model 400A Flame Ionization Detector (FID).

Measures the solvent concentration in the adsorber inlet SLA stream (as PPM ( $v$ ) methane) in the range of $0-10,000 \mathrm{ppm}$ and adsorber exhaust air stream in the range of 0-100 $\operatorname{ppm}(\mathrm{V})$. The automatic range change device provides options for 7 ranges for more accurate measurements: $0-10 \mathrm{ppm}, 0-25 \mathrm{ppm}, 0-100 \mathrm{ppm}$, $0-250 \mathrm{ppm}, 0-1000 \mathrm{ppm}, 0-2500 \mathrm{ppm}$ and $0-10,000$ ppm.

\subsubsection{GA-519 Moisture Analyier}

ondyne Model 1441 analyzer with Model DY-132 moisture probes and Model lo1-s flow cell.

Moisture analyzer measures the dew point of the regen gas stream during the moisture stripping step. At a preset dew point $\left(-20\right.$ to $\left.-25^{\circ} \mathrm{F}\right)$ the regen gas flow is redirected out of the mol sieve bed and into the turbo compressor for solvent stripping.

Range: $-100^{\circ} \mathrm{F}$ to $+80^{\circ} \mathrm{F}$ dew point. 
NUCON IODE771/03 Rev. 2

3.17.3 GA-521 Oxygen Analyzer

Beckman Model 755 oxygen Analyzer.

Measures the level of oxygen in the regen gas stream. The oxygen is purged from the system to a level of $5 \%$ (max.) before starting the stripping of moisture and solvents.

Range: $0-25 \%$

\subsection{Instruments and Controls}

\subsection{8 .1 Computer}

The computer provides the interface between the plant operator and all of the system control devices which are in the computer or are mounted on the pilot plant. Feedback information from the process operating variables is provided by the computer.

The computer is an IBM PC/AT (or equivalent) and is used to run "The FIX"TM software and serves as the operator interface to the system. in-place of a control panel. operating data collected is stored in the computer for future review. The computer also contains software for programming the programmable logic controller.

3.18.2 Programmable Logic Controller

The Programmable Logic controller (PIC) is a Modicon 984-680 with all necessary input and output modules (analog and digital), and logic software to control the operation of the pilot plant.

3.18.3 Computer software 
NUCON 10DE771/03 ReV. 2

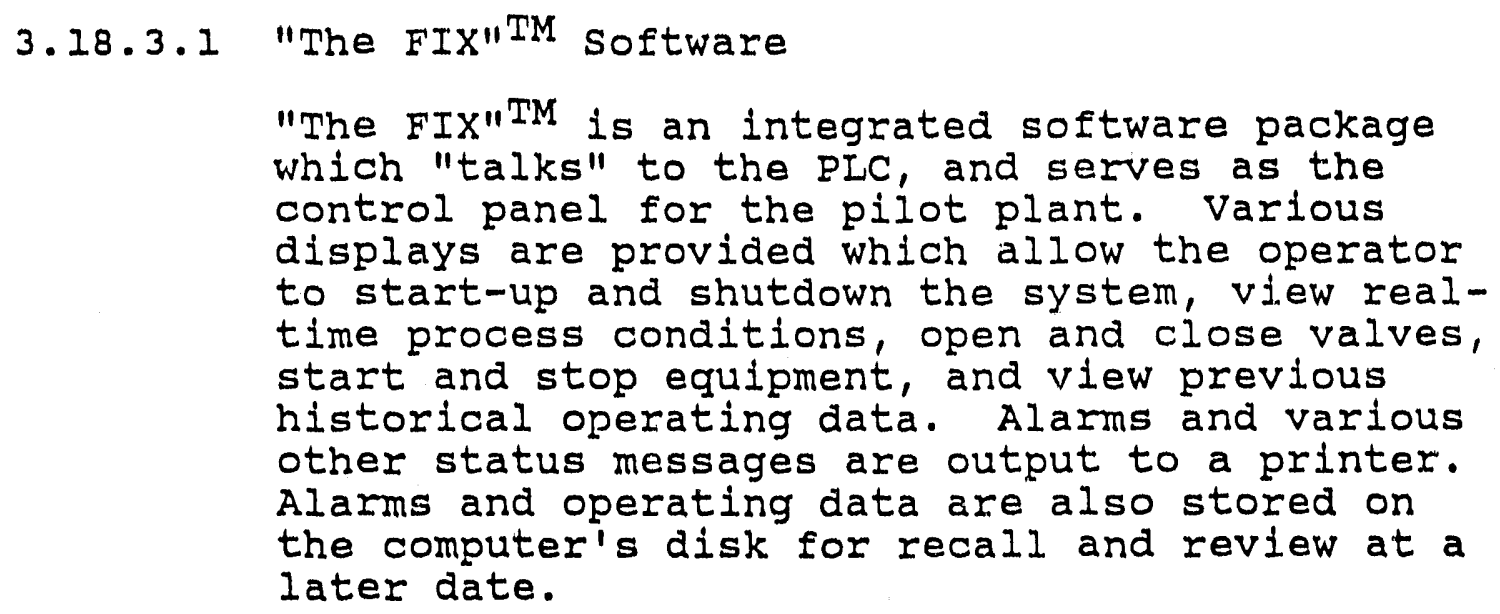

"The FIX" is a Registered Trademark of Intellution, Inc.

"IBM PC/AT" is a Registered Trademark of International business Machines, Inc.

3.18.3.2 PLC Programming software

This software resides in the computer and provides the means for entering and de-bugging the software in the PIC. It provides on-Iine access to, and full hard-copy documentation of, the software.

3.19 Major Instruments

- DPI-101 Panel-mounted. Measures the pressure drop across the $D-1$ carbon bed. Range: 0-15" w.c.

- DPI-201 Panel-mounted. Measures the pressure drop across the $\mathrm{D}-2$ carbon bed. Range: 0-15" w.c.

- DPI-502 Panel-mounted. Measures the pressure drop across the SLA fan $\mathrm{C}-1$. Range: $0-30 "$ w.c.

- DPI-512 Field-mounted. Measures the pressure drop across the roughing compressor inlet strainer.

Range: $0-2 "$ w.c. 
NUCON 1ODE771/03 Rev. 2

a $\quad \mathrm{DPI}-537$

- LT-43!

- IT -549

- $\quad \mathrm{DPT}-538$

- $\mathrm{PT}-532$

- $\quad \mathrm{PT}-547$

- $\quad S C R-529$

- PT-514

- $\mathrm{PT}-539$
Field-mounted. Measures the pressure drop across the turbo compressur inlet filter $\mathrm{F}-4$.

Range: $0-2 "$ w.C.

Level transmitter for separator $\mathrm{S}-1$.

Level control is in the computer.

Range: $0-12 "$ w.c.

Level transmitter for separator $\mathrm{s}-2$. Level control is in the computer.

Range: $0-12$ " w.c.

Turbo compresisor differential. Pressure transmitter.

Range: $0-30$ psid

Regen system pressure transmitter for pressure control of the regen loop. Range: $0-3$ psid

Turoo expander discharge pressure transmitter.

Range: $0-6$ psig

Power controller for both the mol sieve regen gas heater $E-8$ and the solvent strip regen gas heater $E-6$. These two process functions take place sequentially. The electrical rating of the SCR is $30 \mathrm{KW}, 480 \mathrm{~V}, 3 \mathrm{PH}, 60 \mathrm{~Hz}$. (Note: This SCR was with the original pilot plant.)

Roughing compressor discharge pressure transmitter. A high pressure reading is a signal for compressor shutdown. Range: $0-25$ psia

Turbo compressor discharge pressure transmitter. A hioh pressure indicates plugging (freezing) of downstream heat exchangers.

Range: $0-30$ psig 
NUCON 1ODE771/03 ReV. 2
- TE-546
and
$\mathrm{TE}-546 \mathrm{~A}$

$+-+$

$|2|$

\author{
a $T V-546$ \\ $-101-03$. \\ Instrument \\ Number

$\begin{array}{ll}\text { FE-504 } & \text { Upstream C-1 } \\ \text { FT-504 } & \text { At FE-504 } \\ \text { PT-566 } & \text { Upstream C-1 } \\ \text { TE-501 } & \text { Upstream C-1 } \\ \text { TE-101 } & \text { Inside D-1 } \\ \text { TE-106 } & \text { Inside D-1 } \\ \text { TE-201 } & \text { Inside D-2 } \\ \text { TE-206 } & \text { Inside D-2 } \\ F E-561 & \text { Upstream E-2 }\end{array}$

Turbo expander discharge temperature. The miliivolt signal is transmitted directly to the PC. TE-546 and TE-546A are sensing points for cascade temperature control of the expander outlet temperature. The signals from $T E-546$ and $T E-546 A$ are transmitted to the controllers in the computer. The output signal from the computer positions the valve $T V-546$. Operating Range: TE-546: $-80^{\circ} \mathrm{F}$ to $0^{\circ} \mathrm{F}$ TE-546A: $0^{\circ} \mathrm{F}$ to $+120^{\circ} \mathrm{F}$

Control of cooling water flow for exchanger $\mathrm{E}-4$; directly controls the turbo expander inlet temperature. operating Range: 0-10 GPM

3.20 Instruments with Inputs to the computer

Instruments are listed in groups according to process functions related to adsorption and regeneration of the carbon beds and the mol sieve bed as well as product recovery, refer to the P\&IDs: 0771-101-01, -101-02 and

\section{Function}

Inlet SIA stream Flow - CFM

Transmits SLA Flow signal

Inlet SLA stream

Pressure/Transmitter

Inlet SLA stream Temperature

Carbon Bed Inlet Temperature

Carbon Bed outlet Temperature

Carbon Bed Inlet Temperature

Carbon Bed outlet Temperature

Regen Gas stream Flow - CFM 


\begin{tabular}{|c|c|c|}
\hline Instrument & & \\
\hline Number & Location & Function \\
\hline FT-561 & At $F E-561$ & $\begin{array}{l}\text { Transmits Regen Gas Flow } \\
\text { Signal }\end{array}$ \\
\hline$P T-562$ & Upstream E-2 & $\begin{array}{l}\text { Regen Gas stream } \\
\text { Pressure/Transmitter }\end{array}$ \\
\hline$T E-508$ & Upstream E-2 & Regen Gas stream Temperature \\
\hline$P T-514$ & Downstream $\mathrm{C}-2$ & Compressor Discharge Pressure \\
\hline TS -516 & Downstream $\mathrm{C}-2$ & Over Pressure Signal \\
\hline$T E-554$ & Downstream E-3 & Regen Gas Temperature \\
\hline$S V-524$ & Downstream $E-3$ & $\mathrm{O}_{2}$ Purge control \\
\hline$P T-532$ & $\begin{array}{l}\text { Downstream } E-5 \\
\text { or } E-9\end{array}$ & $\begin{array}{l}\text { Regen Gas system Purge } \\
\text { Pressure Control }\end{array}$ \\
\hline$P V-532$ & Nitrogen Line & $\begin{array}{l}\text { Controls } \mathrm{N}_{2} \text { Make Up for system } \\
\text { Low Pressure }\end{array}$ \\
\hline$T E-529$ & Inlet: to $D-3$ & $\begin{array}{l}\text { Temperature Signal to SCR-529 } \\
\text {-Mol Sieve Regen Heater } \\
\text { Control }\end{array}$ \\
\hline$T E-530$ & outlet from $D-3$ & $\begin{array}{l}\text { Mol sieve outlet Gas } \\
\text { Temperature }\end{array}$ \\
\hline$D P T-538$ & Turbo comp. $\mathrm{C}-3$ & $\begin{array}{l}\text { Pressure Rise Across the } \\
\text { Compressor }\end{array}$ \\
\hline$P T-539$ & Downstream $\mathrm{C}-3$ & Compressor Discharge Pressure \\
\hline$D P T-5.15$ & Turbo Expander $\mathrm{C}-3$ & $\begin{array}{l}\text { Pressure Drop Across the } \\
\text { Expander }\end{array}$ \\
\hline$I E-54 I$ & Downstream E-5 & Expander Inlet Temperature \\
\hline$T E-546 A$ & Downstream E-4 & Expander Temperature Control \\
\hline$T E-546$ & Downstream $\mathrm{C}-3$ & Expander outlet Temperature \\
\hline$L T-543$ & At $s-1$ & Level control \\
\hline
\end{tabular}




\begin{tabular}{|c|c|c|}
\hline $\begin{array}{l}\text { Instrument } \\
\text { Number }\end{array}$ & Locat1on & Function \\
\hline$L T-549$ & At $s-2$ & Level Control \\
\hline$F E-544$ & At $s-1$ & $\begin{array}{l}\text { Condensed Product Flow } \\
\text { Measuremint }\end{array}$ \\
\hline$F V-606$ & At $s-1$ & $\begin{array}{l}\text { Condensed Product Separating } \\
\text { Valve }\end{array}$ \\
\hline$F E-550$ & At $s-2$ & $\begin{array}{l}\text { Condensed Product Flow } \\
\text { Measurement }\end{array}$ \\
\hline$F V-607$ & At $s-2$ & $\begin{array}{l}\text { Condensed Product Separating } \\
\text { Valve }\end{array}$ \\
\hline
\end{tabular}

\subsection{MODES OF OPERATION}

$+-+$

$|2|$

$+-+$

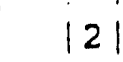

\subsection{General}

The pilot plant is intended to demonstrate the capability of the Brayton Cycle Heat Pump (BCHP) for the recovery of VoC's from exhaust air streams. Two modes of operation have been incorporated into the system for this purpose - (1) Carbon adsorption with BCHP regeneration (BRAYSORB), and (2) Direct condensation of solvents from the SIA stream (BRAYCYCLE).

\subsection{BRAYSORB MOde}

Solvent in the exhaust air (SIA) stream is concentrated by adsorption on carbon and recovered by regeneratio:1 of the saturated bed using the Brayton Cycle Heat Pump technology. The two bed arrangement provides fo: continuous adsorption of solvents. The regeneration cycle consists of four principal steps occurring sequentially:

1) Purging of oxygen from the regen loop.

2) Water stripping of the adsorbent and selective adsorption of moisture one the mol sieve.

3) Voc stripping and recovery. 
NUCON 1ODE771/03 ReV. 2

4) Mol sieve water stripping and readsorption of the water on the adsorbent.

The regeneration cycle is semi continuous. When the regenerating cycle has been completed (step 4 above), the operation is shutdown and the regenerated bed goes on standby status.

\subsubsection{Normal Operation (Adsorption and Regeneration)}

The pilot plant operates in a completely automatic mode and is not time limited. once the utilities are operational, the operator initiates the START funotion and from there on, the PIC and the computer will execute the programed commands for all functions. Shutdown of the system is executed by the operator command.

\subsubsection{Emergency Operation}

The adsorption cycle can function in the normal mode (conditions permitting) and continue to operate up to the point of solvent breakthrough. The SLA inlet and outlet valves and SLA fan can be manualiy operated from the computer.

The regeneration cycle is not intended to be cperated manually. In the event of an emergency, the regeneration cycle will be shut down.

\subsection{BRAYCYCLE MOde}

The solvent laden air (SLA) enters the system at E-1 by draft from $\mathrm{C}-1$ SIA blower. The adsorbers are bypassed and the SIA flows directly to the inlet to the roughing compressor $\mathrm{C}-2$. The mol sieve is bypassed and the SLA passes to the Brayton Cycle Heat Pump (BCHP) $\mathrm{C}-3$ and refrigeration condenser $E-5$ where solvent is condensed and collected in $S-1$ and $5-2$. The exhaust air stream is vented to atmosphere at the outlet of $E-5$. If the entering SIA contains moisture, the cryogenic section will eventually freeze due to the build up of ice and result in early shut down. 
NUCON 1ODE771/03 ReV. 2

4.3.1 Normal Operation

Before starting the SLA flow, the cryogenic section is cooled to the operating temperature $\left(-80^{\circ} \mathrm{F}\right)$ by closed loop recirculation. The flow is from $\mathrm{C}-2$ to $\mathrm{C}-3$ to $\mathrm{E}-5$ and return to $\mathrm{C}-2$. After cool down, the SIA flow is initiated and the flow path is $C-1$ to $C-2$ to $C-3$ to $E-5$ and the vent to the atmosphere.

If there is no molsture in the SLA, the operation can continue indefinitely. If the SIA contains molsture, the water will condense and freeze in E-5. Eventually, the lce will cause plugging of flow path and shutdown will be required. The pilot plant is not equipped to remove moisture as would be expected of a full scale plant.

4.3.2 Freeze/Thaw Operation

Freezing of the low temperature exchanger and related piping will result in a shut down of the process. Thawirg of the equipment can be achieved by passing warm air through the return side of the exchanger $E-5$ and venting to atmosphere.

Alternatively, the thawing process can be achieved by normal conduction/convection by allowing the equipment to remain in the shutdown mode until thawing occurs.

The water resulting from the thawing operation is removed through the condensate piping at $s-1$.

\subsection{CODES AND STANDARDS}

The following codes, standards and regulatory requirements and cther documents shall be utilized to the extent required by the design.

5.1 American Institute of steel construction (AISC)- Eighth Edition - 1988

5.2 American National Standards Institute (ANSI)

Chemical plant Piping Code 1331.11976 as Amended 
NUCON 1ODE771/03 Rev. 2

5.3 American Society of Mechanical Engineers (ASME) 1980

- Section VIII Division 1, Pressure Vessels

- Section IX Welding Specification

- Section II Ferrous Materlals specification

- Section IV Non-Ferrous Materlais Specifications

5.4 National Fire Protection Assoctation (NFPA)

- NFPA NO. 70-1987 National Electríc Code (NEC)

5.5 American Welding Soclety (AWS)

- AWS DI.1 - 1.984 structural Welding Code (NEMA)

5.6 National Electrical Manufacturer's Association (NEMA)

- NEMA 1C5-6-1983 Enclosures for Industrial controls

5.7 Tubular Exchanger Manufacturer's Association (TEMA)

5.8 Air Movement Control Association (AMCA)

- AMCA 201-1985 Fans and systems

6.0 DESIGN CONDITIONS

6.1 General

The pilot plant will be operated at a number of sites in Southern California - which have not been identified. In general, the system will be designed to be flexible and should handle the full spectrum of solvents and concentrations expected of candidate host sites. At this time, site specific operating conditions and specific solvents are not known. The computer and PIC programs will be accessible and will be modified to meet the local requirements before start-up. 
NUCON 1ODE771/03 REV. 2

6.2 Design Conditions

6.2.1 Adsorption

- Inlet conditions

Fluid - Solvent Laden Air (SIA)

FlOW, SCFM

250

Temperature, $F$

Amblent to 300

Pressure, Inches w.c. 0 to -0.3

- solvent Loading

solvent

Solvent Concentration $0.1 \mathrm{lb} / \mathrm{min}$. (max)

VOC

- Exhaust Conditions

Breakthrough control
of Solvents
0 to $50 \mathrm{ppm}$

6.2.2 Utilities

- Electrical

$\begin{array}{lr}\text { Motors } & 460 \mathrm{~V} / 3 \mathrm{PH} / 60 \mathrm{~Hz} \\ \text { Control } & 120 \mathrm{~V} / \mathrm{I} \mathrm{PH} / 60 \mathrm{~Hz} \\ \text { Hazardous Area } & \\ \text { Classification } & \text { Class 1, GrD, Div. } 2\end{array}$

- other Utilities

cooling water

Pressure, psig $50 \pm 10$

Temperature, "F $\quad 70 \pm 10$

Compressed Air, psig $80 \pm 10$

Nitrogen

Pressure, psig $\quad 90 \pm 10$

Minimum Purity, \% 99

7.0 ENVIRONMENTAL CONDITIONS

The following environmental conditions for southern

California will be considered in the design.

- The pilot plant will be located outdoors. 
NUCON 1ODE771/03 ReV. 2

- Dry Bulb Temperatures

$$
\begin{aligned}
& \text { Summer, } \cdot F \quad 85-105 \text { (Normal) } \\
& \text { Winter, } \cdot F \quad 30 \text { (Design) }
\end{aligned}
$$

8.0 INTERFACE REQUIREMENTS - Process \& Utilities Furnished by Host Site

\subsection{General}

The portable pilot plant is intended to be installed on a temporary basis at several locations. Interfacing with each installation is to be managed by using standard fittings for utlilties and process connections.

The fittings to be supplied are identifled below.

8.2 Process Connections

- Solvent Laden Air (SLA) Inlet - 4" - 150\# L.J. Forged Steel Flanged nozzle.

- Recovered Product outlet - " - MNPT, Sched. 10 $316 \mathrm{SS}$

8.3 Utilities Connections

$$
\begin{aligned}
& \text { - Cooling Water - 2" - 150\# S.0. Flange, CS } \\
& \text { - Nitrogen - " - MNPT, Sched. 40, CS } \\
& \text { - Compressed Air - " - MNPT, sched. 40, CS } \\
& \text { * Electrical - 460V, } 3 \mathrm{PH}, 60 \mathrm{~Hz}, 100 \mathrm{~A} \\
& 120 \mathrm{~V}, 1 \mathrm{PH}, 60 \mathrm{~Hz}, 30 \mathrm{~A}
\end{aligned}
$$

\subsection{MATERIAL REQUIREMENTS}

9.1 The solvents that will be in the SIA streams have not been fully identifled, however, ketones, chlorides and trace quantities of their degradation products - acetic acid, formic acid and HCl -are anticipated. The absence of steam and water in the process reduces the risks of acid attack. Further, the limited life of the test program reduces the chance for failure of equipment. 
NUCON 1ODE771/03 Rev. 2

The materials of construction of the equipment already in place on the skid that will be used for this program are made of Type 316 SS.

$+-+$

$|2|$

9.2 Materials of Construction for Various Equipment

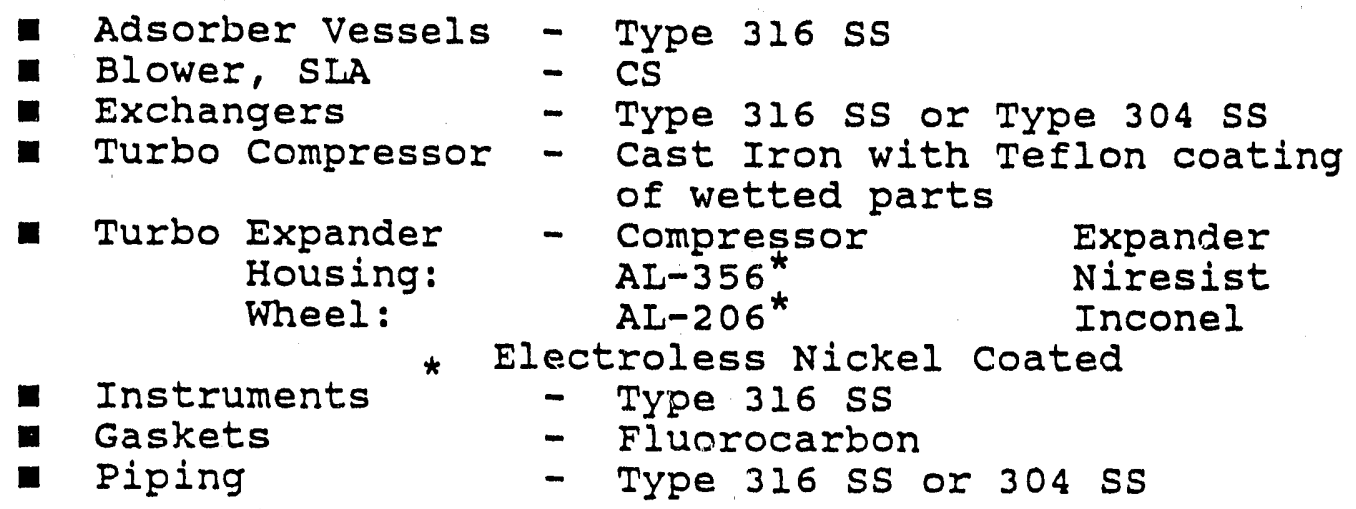

10.0 MECHANICAL REQUIREMENTS

10.1 There ure no mechanical requirements due to shock or reaction forces.

10.2 Forces due to thermal stress will be reduced or eliminated by the use of expansion joints.

11.0 STRUCTURAL REQUIREMENTS

11.1 Supports for piping and equipment will be designed for the loads and for vibration related to transport of the pilot plant.

12.0 ELECTRICAL REQUIREMENTS

12.1 Power - 480V, $3 \mathrm{PH}, 60 \mathrm{~Hz}$ - (Connected KW):

- Blower C-I

- Compressor $\mathrm{C}-2$

- Regen Heater E-6

- Mol Sieve Heater $E-9$

12.2 Control - $120 \mathrm{~V}, I \mathrm{PH}, 60 \mathrm{~Hz}$

- Instrument Panel

\section{$12.2 \mathrm{control}-120 \mathrm{~V}, \mathrm{I} \mathrm{PH,} 60 \mathrm{~Hz}$}

$2.2 \mathrm{KW}$

$15 \mathrm{KW}$

$12 \mathrm{KW}$

$12 \mathrm{KW}$

Instrument Panel 
NUCON 1ODE771/03 ReV. 2

13.0 FAILURE EFFECTS REQUIREMENTS

13.1 Failure of any component of the system will be cause for shut down.

13.2 For any extended shut down of the system, the adsorber vessels will be isolated and purged with nitrogen to reduce the oxygen concentration to $5 \%$ or less.

14.0 ACCESSIBILITY, MAINTENANCE, REPAIR AND IN-SERVICE INSPECTION REQUIREMENTS

Layout of equipment will be such that all equipment is accessible and that high-maintenance items can be readily removed for service.

\subsection{PERSONNEL REQUIREMENTS}

15.1 The system will be completely automatic after start-up from the computer, by the operator.

15.2 Shut down is from the computer, by the operator.

15.3 The extent of operator monitoring will be addressed later.

\subsection{TRANSPORTATION REQUIREMENTS}

16.1 The pilot plant will be permanently mounted on a trailer for hauling around the country.

16.2 The legal limits for dimensions of the trailer and pilot plant are:

Overall Height (including trailer) $-13^{\prime}-6^{\prime \prime}$
Width
Ijength
$-48^{\prime}-6^{\prime \prime}$

\subsection{FIRE PROTECTION REQUIREMENTS}

17.1 The system will be connected to a nitrogen supply to permit blanketing of the adsorbers in the event of a fire.

17.2 When a carbon bed contains oxygenated solvents, and shut down of the system is required, the bed will immediately be blanketed with nitrogen. 
NUCON 1ODE771/03 Rev. 2

17.3 Local plant regulations will be reviewed for compliance before start-up. 

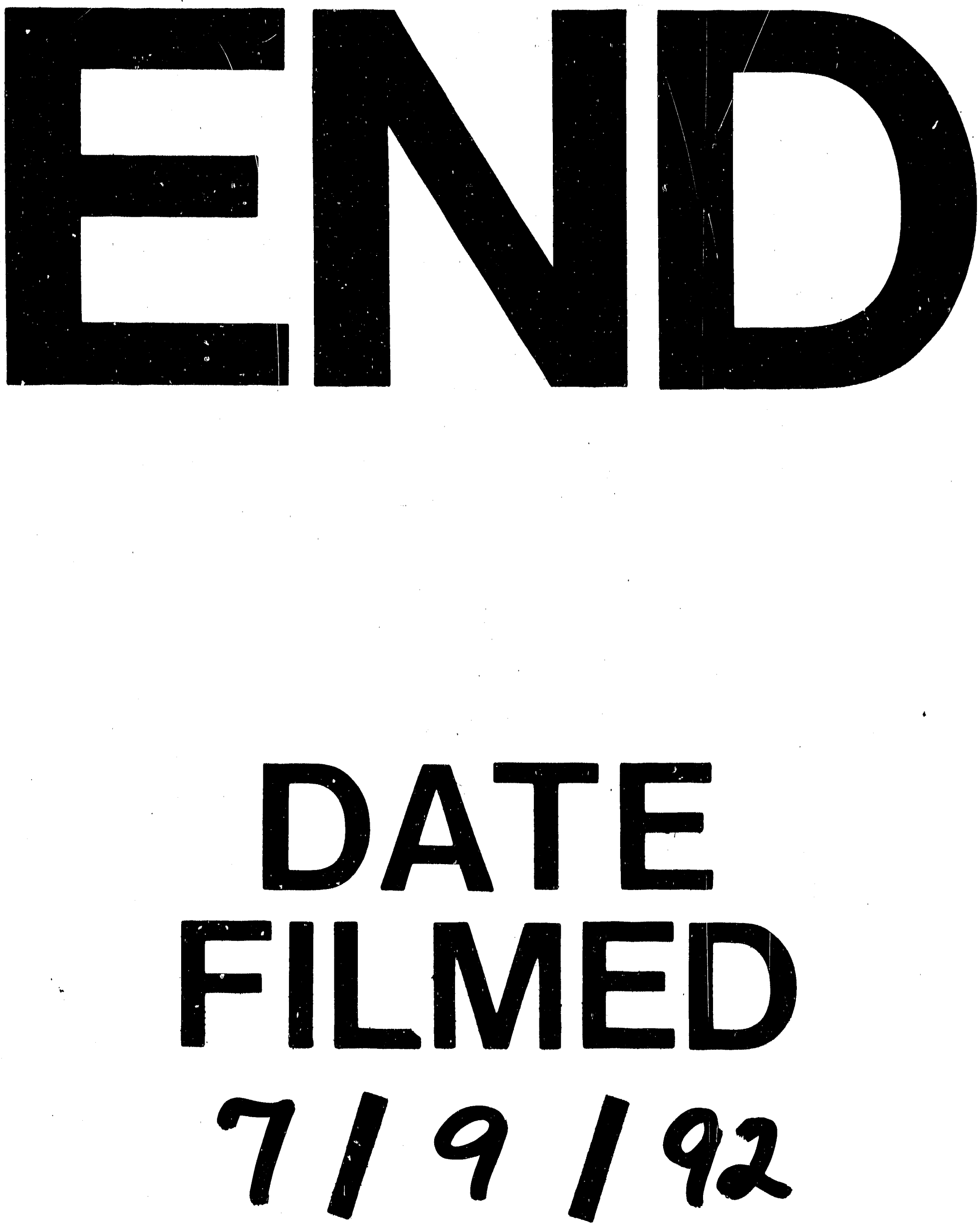

1 
